\title{
AVALIAÇÃO DE MÉTODOS DE RECOMENDAÇÃO DE CALAGEM EM SOLOS DO MUNICÍPIO DE PIRACICABA
}

\author{
JAIME ANTONIO DE ALMEIDA
}

Orientador: Prof. TOSHIAKI KINJO

\begin{abstract}
Dissertação apresentada à Escola Superior de Agricultura "Luiz de Queiroz", da Universidade de São Paulo, para obtenção do Título de Mestre em Agronomia - área de concentração: Solos $\theta$ Nutrição de Plantas.
\end{abstract}

PIRACICABA

Estado de São Paulo - Brasil Junho, 1984 
À minha esposa Cleusa, pelo incentivo e compreen são *

Aos meus filhos Eduardo e Daniel.

dedico 


\section{AGRADECIMENTOS}

Agradeço às seguintes pessoas e instituições. que direta ou indiretamente colaboraram para a execução deste trabal ho:

- Prof. Dr. Toshiaki Kinjo, pela orientação e atenção dedicadas.

- Dr. Bernardo Van Raij, pelo incentivo.

- Prof. Paulo Roberto Ernani, pelo incentivo, apoio e sugestôes.

- Colega João Baptista Palhano.

- À FIDENE, Fundação de Integração, Desenvolvi mento e Educação do Noroeste do Estado, Ijuí RS.

- À CAPES, pela concessão da bol sa de estudos.

- Ao OSW (Okumenisches Studienwerk e.V.), Bochum, Al emanha, pela concessão de auxil io fi nanceiro, através da Igreja Evangélica de Confissão Luterana do Brasil - IECLB, Porto Alegre, RS. 
Página

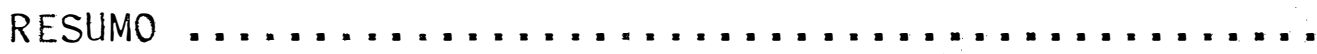
SUMMARY

$\mathbf{i}$ viii

I. INTRODUÇÃO

2. REVISÃO DE LITERATURA

2.1. Natureza da acidez dos solos ............

2.2. Propriedades dos solos que influem na sua

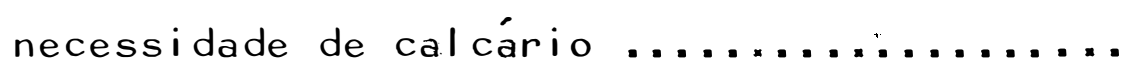

2.3. Métodos de recomendação de calagem ........ 2.3.1. Métodos que utilizam soluções tampona

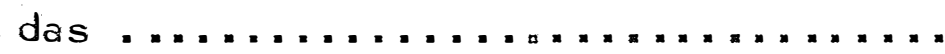

2.3.2. Método do alumínio trocável ........ 2.3.3. Método da saturação de bases .......

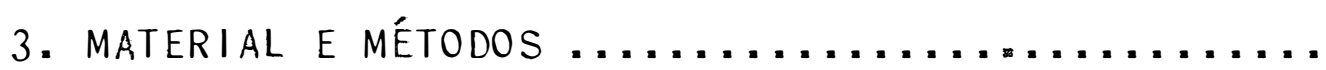

3.1. Solos estudados .....................

3.2. Preparo das amostras $\ldots \ldots \ldots \ldots \ldots \ldots \ldots \ldots \ldots$

3.3. Tratamentos utilizados $\ldots \ldots \ldots \ldots \ldots \ldots \ldots \ldots$

3.4 . Determinações anal íticas ..................

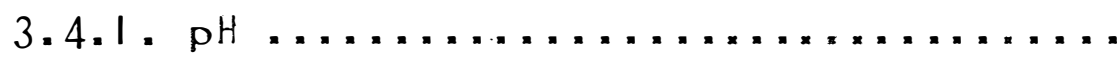

3.4.2. Alumínio trocável

$x=x=$

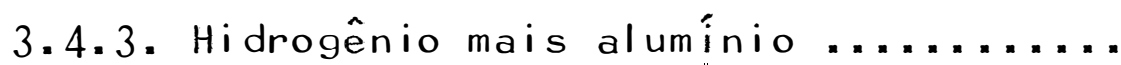

3.4.4. Cál cio mais magnésio trocáveis .....

3.4.5. Potássio e fósforo extraíveis ......

3.4 .6 . Matéria orgânica $\ldots \ldots \ldots \ldots \ldots \ldots \ldots$

3.4.7. Cál culo da soma de bases, saturação em bases e capacidade de troca de cátions $\ldots \ldots \ldots \ldots \ldots \ldots \ldots \ldots \ldots \ldots \ldots \ldots \ldots$

3.4.8. Análi se granulométrica ......... 
3.5. Métodos de recomendação da necessidade de

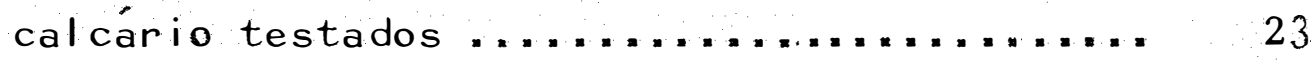

3.5 .1 . Método do alumínio trocável ....... 23

3.5.2. Método do acetato de cálcio ........ 24

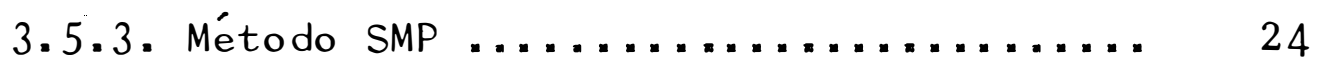

3.5.4. Méţodo da saturação em bases ........ 24

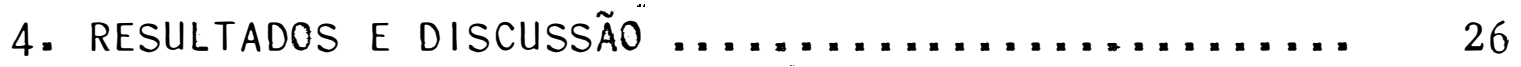

4.1. Caracterização geral dos solos estudados .... 26

4.2. Incubação dos solos com carbonato de cálcio " 29

4.3. Rel ação entre o $\mathrm{pH}$ em $\mathrm{H}_{2} \mathrm{O}$ e o pH em $\mathrm{CaCl}_{2} \ldots 3$...

4.4. Contribuição da matéria orgânica e da argila para a CTC dos solos ......................... 34

4.5. Propriedades dos solos e sua influência na

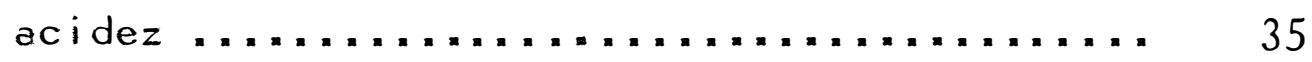

4.6. Relação entre o pHSMP e o teor de $\left(\mathrm{H}^{\mathrm{O}}+\mathrm{Al}^{+3}\right) \ldots$

4.7. Rel ação entre o $\mathrm{pH}$ em $\mathrm{H}_{2} \mathrm{O} \in$ em $\mathrm{CaCl}_{2}$ e a satú ração em bases $\ldots \ldots \ldots \ldots \ldots \ldots \ldots \ldots \ldots \ldots \ldots \ldots$

4.8. Calibração do método SMP para os solos estuda

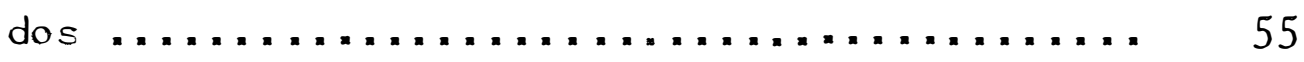

4.9. Quantidades de carbonato de cálcio indicadas pelos métodos testados ................ 57

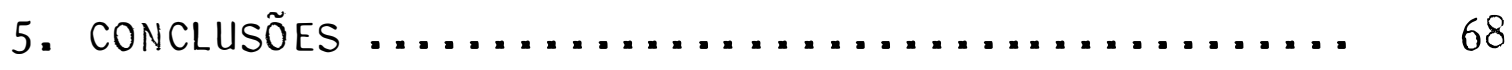

6. LITERATURA CITADA ................... 70

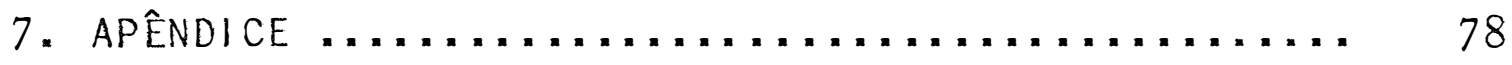




\section{AVALIAÇÃO DE MÉTOdOS DE RECOMENDAÇÃO DE CALAGEM EM SOLOS DO MUNICIPIO DE PIRACICABA.}

Jaime Antonio de Almeida Orientador: Prof. Toshiaki Kinjo

RESUMO

Vinte e três amostras de terra do município de Piracicaba, SP, de superficie e subsuperficie, foram incubadas com doses crescentes de carbonato de cálcio p.a. Curvas de neutralização foram el aboradas para cada um dos solos, e por interpolação linear foram calculadas as quantidades de carbonato de cálcio necessárias para elevação do $\mathrm{pH}$ em $\mathrm{H}_{2} \mathrm{O}$ e pH em $\mathrm{CaCl}_{2}$ a três valores distintos. Relacionou-se algumas propriedades dos solos que poderiam influenciar na CTC e na necessidade de calcário dos solos, bem como testaram-se diver sos métodos de recomendação das necessidades de calcário por comparação com as doses indicadas pelo método de incubação. o conteúdo de argila e de matéria orgânica mos trou-se correlacionado com a CTC dos solos. Os teores de $\left(\mathrm{H}^{\mathrm{O}}+\mathrm{Al}^{3+}\right), \mathrm{CTC}$ a $\mathrm{pH} 7,0$, teor de argila e teor de matéria orgânica foram, por ordem de importância, as propriedades que mais influenciaram na necessidade de calcário para elevação 
do $\mathrm{pH}$ em $\mathrm{H}_{2} \mathrm{O}$ a 6,5 e $\mathrm{pH}$ em $\mathrm{CaCl}_{2}$ a 5,9 em virtude dos coefi cientes de correl ação encontrados. Os valores de $\mathrm{pH}$ da sus pensão solo:água: solução SMP mostraram-se altamente correlacionados com os teores de $\mathrm{H}^{\mathbf{O}}+\mathrm{Al}^{3+}$ determinados pelo método de extração com solução de acetato de cálcio I N tamponada a $\mathrm{pH} 7,0$, vizualizando a possibilidade de se estimar a CTC dos solos através da determinação da soma de bases, acrescida aos valores de $\left(H^{\circ}+A_{r}{ }^{3+}\right)$ obtida por leitura direta do $\mathrm{pH}$ SMP, utilizando-se equação de regressão neste sentido.

Dentre os métodos de recomendação da necessidade de calagem testados, o do acetato de cálcio mostrou-se o mais eficiente, quando comparado com as quantidades de carbonato de cálcio indicadas pelo método da incubação; os métodos tampão SMP e saturação em bases mostraram-se também efetivos, embora menos que o anterior. 0 coeficiente de correlação obtido quando relacionou-se as doses indicadas pelo método do alumínio trocável com as indicadas pelo método da incubação foi o mais baixo dentre os métodos testados.

Os coeficientes de correlação foram sempre maiores, para todos os métodos testados, quando as doses indicadas pelos mesmos foram comparadas com as indicadas pelo método da incubação para el evar o $\mathrm{pH}$ em $\mathrm{CaCl}_{2}$ 0, OlM a valo res estipulados, em relação aos coeficientes obtidos por com paração com o método da incubação para elevar o pH em $\mathrm{H}_{2} \mathrm{O}$ também a valores pré-estabelecidos. Isto pode ser atribuido a menor variação nos valores de $\mathrm{pH}$ quando se usam soluções salinas, fornecendo valores mais reais para a necessidade de calcário dos solos, em virtude da eliminação do efeito de sais contidos nas diferentes amostras. 


\section{LIME REQUIREMENTS METHODS IN SOILS OF PIRACICABA}

Jaime Antonio de Almeida Adviser: Prof. Toshiaki Kinjo

SUMMARY

Twenty three superficial and subsuperficial soil samples of Piracicaba, São Paulo, Brazil, were incubated by increased rates of $\mathrm{CaCO}_{3} \mathrm{P}$. a. Neutralization curves were elaborated for each one, and the amounts of $\mathrm{CaCO}_{3}$ needed to rise the soil $\mathrm{pH}$, in water and $\mathrm{CaCl}_{2}$, at three different values, were obstained by 1 inear interpolation. Some soil properties that would influence cation exchange capacity (CEC) and 1 ime requirement were 1 isted. Lime amounts of four lime requirements methods were related with the incubation method. $\mathrm{Cl}$ ay and organic matter contents of soils showed high correlation with cation exchange capacity (CEC). The correlation coefficients showed that $\mathrm{H}^{\mathrm{O}}+\mathrm{Al}^{3+}$ content, CEC at $\mathrm{pH} 7,0, \mathrm{cl}$ ay and organic matter, in this order, were the most important properties changing 1 ime requirements, to rise the pH to 6,5, in water, and to 5,9, in $\mathrm{CaCl}_{2}$. The $\mathrm{pH}$ values of mixed soil:water:SMP solution were highly correlated with $\mathrm{H}^{\mathrm{O}}+\mathrm{Al}^{3+}$ levels, as extracted by the IN Ca acetate solution, buffered $\mathrm{pH} 7,0$. The possibility of estimate the 
soil CEC by the sum of bases determination, adding the $\mathrm{H}^{\mathrm{O}}+\mathrm{Al}^{3+}$ values obtained by direct reading of $\mathrm{pH}$ SMP and using a regression equantion in this way highlighted.

The $\mathrm{Ca}$ acetate methods was the most efficient of all I ime requirements methods tested, when compared with the amounts of cal,cium carbonate indicated by the incubation method. The SMP buffer and the base saturation methods were al so effective but, not as the first. When relating the amounts indicated by the exchangeable aluminium and incubation methods, the resulting correlation coefficient was not significant.

The correlation coefficients were higher, for all methods, when the indicated amounts were compared with the incubation method indications to $r$ ise the $\mathrm{pH}$ in $\mathrm{CaCl}_{2}, 0,01 \mathrm{M}$ to given values, than the coefficients obstained by comparing with the incubation method to $r i s e ~ p H$ in water to given values. This was due to the little variation in $\mathrm{pH}$ values when using saline solutions, given more precise amounts of l ime required, el iminating the effects of salts present in the different samples. 


\section{INTRODUÇÃO}

A calagem é uma prática atualmente muito difun dida em várias regiões brasileiras, especialmente na sul e Su deste, onde concentramse grande parte da produção agrícola na cional, e onde os solos são bastante ácidos, afetando o desen volvimento normal das culturas.

Embora a acidez dos solos constitua, normalmen te, um fator negativo ao desenvolvimento das plantas, o estabelecimento de doses adequadas de cal agem bem como o pH a ser alcançado, é tarefa mais difícil, tendo em vista que as várias espécies vegetais tem graus distintos de tolerância a acidez e portanto podem reagir também de forma distinta à calagem.

Muitos métodos têm sido propostos para avaliar a exigência de calcário dos solos, a maioria deles já tendo sido testados em nossas condições. Dentre os mais utilizados no Brasil destacam-se o método do alumínio trocável e o do tampão Sivp.

O método do alumínio trocável teve sua difusão no país, a partir da divulgação do Programa Internacional de Análise de Solos, em 1965. Pode estar associado ou não ao mé- 
todo da elevação dos teores de cálcio mais magnésio do solo a valores compreendidos entre 2 e 3 meq/l00g de solo, é é ó método que predomina em grande parte dos estados brasileiros nas recomendaçôes rotineiras de calcário. Já no Rio Grande do Sul e Santa Catarina, emprega-se o método conhecido como SMP, que prevê a el evação do $\mathrm{pH}$ ao valor 6,0 .

Recentemente, foi introduzido no estado de São Paulo um novo critério para recomendação das doses de calcá rio, constituindo-se numa adaptação ao método proposto por CATANI \& GALLO (1955), e prevê a quantidade a ser apl icada em função da el evação da saturação em bases do solo a distintos valores, dependendo da cultura a ser implantada.

Os objetivos do presente trabalho foram o de testar, para solos do municipio de Firacicaba - SP, alguns dos principais métodos de avaliação das doses de calcário a tualmente em uso, tendo como base de comparação o método da incubação dos solos com doses crescentes de carbonato de cálcio: 


\section{REVISÃO DE LITERATURA}

$2 \times 1$. Natureza da acidez dos solos

A presença dos ions $\mathrm{Al}^{3+}$ e $\mathrm{H}^{+}$na fração da car 9a negativa permanente das argilas em solos ácidos está intimamente rel acionada com a acidez destes solos, constituindo o que geralmente denomina-se acidez de troca. A dualidade do pa pel do cátion alumíniohexahidroneo como trocador de próton (dependente do $\mathrm{pH}$ ) e ao mesmo tempo a sua trocabilidade em $\mathrm{KCl}$, fez com que houvesse uma vascilação histórica na nomenclatura entre o "H trocável" e o "Al trocável" como causas da acidez dos solos (JACKSON, 1963).

JENNY (1961) fez um ótimo relato acerca do desenvolvimento das diversas teorias. Assim Veitch, em 1904, mos trou que em extratos obtidos por meio de sucessivas Iavagens com $\mathrm{NaCl}$ em solos ácidos com baixo teor de húmus, havia a pre sença de alumínio, ferro e manganês, e atribuiu que a fonte de acidez dos solos era devida a sua fração mineral, reconhecendo entre as várias reaçoes possíveis o deslocamento do alu mínio pelo sódio. Isto diferia radicalmente da teoria predomi 
nante então, segundo a qual a acidez era originada dos ácidos húmicos presentes no solo. A hipótese de que o alumínio seria o principal agente causador da "acidez trocável" foi sustenta da ainda por Daikuhara em 1914 e Kappen em 1916. Ainda segundo o autor, os trabal hos de Bradfield em 1923, vieram novamen te modificar os conceitos sobre a acidez dos solos. Esta se ria originada dos ions $\mathrm{H}^{+}$dos coloides argilosos (teoria do $\mathrm{H}_{-}$ argila). Paver e Marshall em 1934, trouxeram novos conhecimen tos a ciência do solo quando propuseram a ligação H-Al-argila, ao invés de somente $H_{*}$ Outros trabalhos seguiram-se a este, como os de Schofield em 1946, Chernov em 1947, Russel em 1950 e Coleman de 1952 a 1954, retornando assim a teoria preconiza da por Veitch.

0 estudo do comportamento de argilas acidifica das por meios artificiais foi enfatizado em vários trabalhos a partir da década de 50, como os de HARWARD \& COLEMAN (1954), LOW (1955), COLEMAN \& CRAIG (I96I) e DAVIS et alii (1962), den tre outros, tendo esclarecido amplamente o papel do $\mathrm{H}^{+} \mathrm{e}$ do $\mathrm{Al}^{3+}$ como componentes da"acidez trocável" dos solos. Ficou evidenciado principalmente que o caráter ácido fraco das sus pensões de argila era devido ao Al3t, e que as argilas satura das com $\mathrm{H}^{+}$não eram estáveis e se transformavam expontaneamen

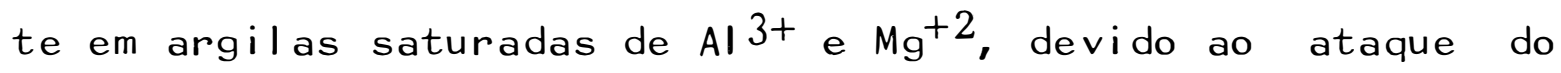
$\mathrm{H}^{+}$à rede cristal ina dos minerais de àrgila* Além de contribui rem para explicar os pequenos teores de hidrogênio comumente encontrados nos solos, estes trabalhos serviram para elucidar que o alumínio trocável é consequência e não causa a acidez dos solos.

Em soluções fortemente ácidas o alumínio ocorre como um cation trivalente complexo, no qual um átomo de alumínio está circundado por seis moléculas de água em coorde- 
nação formando $\mathrm{Al}\left(\mathrm{H}_{2} \mathrm{O}\right) \mathrm{6}^{+++}$(MC LEAN, 1965), e denominado "aluminiohexahidroneo" segundo termo proposto por JACKSON (1963). Quando o pH aumenta, primeiro um e depois dois grupos de água perdem um ion $\mathrm{H}^{+}$(ou uma molécula de água é deslocada por um íon $\mathrm{OH}^{-}$) formando cátions hidroxialumínicos mono ou divalen tes (Mc LEAN, 1965): Esta reação pode ser representada, segun do BLACK (1975), pelas seguintes equações:

$$
\begin{aligned}
& {\left[\mathrm{Al}\left(\mathrm{H}_{2} \mathrm{O}\right)_{6}\right]^{+++}+\mathrm{H}_{2} \mathrm{O} \rightleftharpoons\left[\mathrm{AlOH}\left(\mathrm{H}_{2} \mathrm{O}\right)_{5}\right]^{++}+\mathrm{H}_{3} \mathrm{O}^{+}} \\
& {\left[\mathrm{AlOH}\left(\mathrm{H}_{2} \mathrm{O}\right)_{5}\right]^{++}+\mathrm{H}_{2} \mathrm{O} \rightleftharpoons\left[\mathrm{Al}(\mathrm{OH})_{2}\left(\mathrm{H}_{2} \mathrm{O}\right)_{4}\right]^{+}+\mathrm{H}_{3} \mathrm{O}^{+}} \\
& {\left[\mathrm{Al}(\mathrm{OH})_{2}\left(\mathrm{H}_{2} \mathrm{O}\right)_{4}\right]^{++}+\mathrm{H}_{2} \mathrm{O} \rightleftharpoons\left[\mathrm{Al}(\mathrm{OH})_{3}\left(\mathrm{H}_{2} \mathrm{O}\right)_{3}\right]+\mathrm{H}_{3} \mathrm{O}^{+}}
\end{aligned}
$$

As diversas formas que o aluminio toma em fun-

ção da variação do $\mathrm{pH}$ do solo, podem ser representadas simples mente como $\mathrm{Al}^{3+}, \mathrm{Al}(\mathrm{OH})^{2+}$ e $\mathrm{Al}(\mathrm{OH})_{2}^{+}$, segundo JACKSON (I 963). Algumas destas formas permanecem na solução do solo, muitas podem estar adsorvidas como monômeros aos sitios de troca caś tiônica do solo e, além disso, podem ser adsorvidas e então polimerizadas na superfície dos minerais de argila ou pela ma téria orgânica do solo (McLEAN, 1976).

PIONKE \& COREY (1967) sugerem a ocorrência das seguintes reações com o alumínio acídico no solo:

$$
\begin{aligned}
& \mathrm{Al}(\mathrm{OH})_{3} \\
& 11 \\
& \text { Al y }(\mathrm{OH}) \underset{8 \mathrm{~b}-\mathrm{z}}{2+} \\
& 1 \mathrm{l} \\
& \text { Al }\left(\mathrm{OH}^{\mathrm{OH}}\right)^{2+} \\
& \mathrm{Al}-\mathrm{MO} \rightleftharpoons \mathrm{Al}^{3+} \rightleftharpoons \mathrm{Al}-\mathrm{x} \\
& \text { Dentro deste esquema, } \mathrm{Al}^{3+} \text { representa a ativi- }
\end{aligned}
$$


zado e proyavelmente residindo na superficie das partículas de argila. 0 aumento do $\mathrm{pH}$ induziria a transformação das formas trocáveis e polimerizadas em $\mathrm{Al}(\mathrm{OH})_{3}$. Ao contrário, o a baixamento do $\mathrm{pH}$ tenderia a transformar as formas não trocá veis e o $\mathrm{Al}(\mathrm{OH})_{3}$ em formas trocáveis, dada a reversibilidade da reação:

Para uma mesma concentração de alumínio, consi derando-se o pH constante, um incremento no teor de matéria orgânica aumentaria a forma não trocável do alumínio, devido a complexação da forma trocável pelo complexo orgânico do so1o. Na mesma situação dada acima, aumentando-se o teor de argila, aumentaria o alumínio trocável as expensas do alumínio I igado a matéria orgânica, confirmando o aparente equilibrio entre as diversas formas do aluminio no solo.

Vários trabalhos (COLEMAN et alii, 1959; LIN \& COLEMAN, 1960 e BHUMBLA \& MC LEAN, 1965) indicam que as formas trocáveis do alumínio podem ser extraidas com soluções de sais neutros, não tamponados, sendo comumente, referidas como acidez trocável (COLEMAN \& THOMAS, 1967). LIN \& COLEMAN(I960) e DEVAN \& RICH (.I970) destacam o $\mathrm{KCl}$ como o extrator de maior eficiência nesta determinação. Segundo KAMPRATH (1970), abaixo de $\mathrm{pH}$ 5,4 a capacidade tamponante dos solos é devida prima riamente ao alumínio trocável.

As formas parcialmente hidrolizadas do alumi nio parecem estar tão fortemente adsorvidas ao complexo colo i dal do solo, que näo podem ser extraídas por soluções de sais não tamponados (THOMAS, 1960). Comparando vários métodos de extração do alumínio em solos e argilas, MC LEAN et ali i(1959) mostram que em condições extremamente ácidas, com $\mathrm{pH}$ er torno de 4,0 , os sais não tamponados extraem quantidades equivalentes de alumínio ao $\mathrm{NH}_{4} \mathrm{OAC}$ a $\mathrm{pH} 4,8$, entretanto com o aumento 
do $\mathrm{pH}$, este último extrai progressivamente quantidades máiores de alumínio. Trabalhos posteriores, de PRATT \& BAIR (1961), por outro lado, indicam que o $\mathrm{NH}_{4} \mathrm{OAC}$ a $\mathrm{pH} 4,8$ extrai outras formas adicionais de alumínio, além da trocável. Es tas incluiriam uma fração mais reativa dos polímeros de hi dróxido de alumínio e alumínio complexado pela matéria orgânica(PIONKE \& COREY, I967).

Embora exista uma generalização no sentido de tomar-se a acidez extraida pelo $\mathrm{KCl} / \mathrm{N}$ como sendo totalmente alumínio trocável, os trabalhos de YUAN (1959, 1963) na Flórida mostraram que o hidrogênio trocável em certos casos pode contribuir significativamente para a acidez trocável. Os resultados obtidos, segundo COLEMAN \& THOMAS (1967) podem ser atribuidos a presença de elevados teores de matéria orgâ nica nos casos estudados. " Conclusões semel hantes foram obtidas por Schwertmann, em 1961 (JACKSON, 1963; BLACK, 1975), o qual verificou que quantidades apreciáveis de hidrogênio tro cável somente eram encontradas em extratos de $\mathrm{KCl}$ dos solos ácidos ricos em matéria orgânica.

COLEMAN \& THOMAS ( 1967 ), com base em trabalhos anteriores, afirmam que grande parte da acidez do solo acima de $\mathrm{pH} 5,5$ é titulável, mas não trocável, sendo deslocada somente por sais tamponados. Os extratores mais comumente utilizados para medir a acidez titulável dos solos são o acetato de amônio a pH 7,0 e o cloreto de bário mais trietanol ami na a pH 8,2, e servem para a determinação da acidez dependen te do $\mathrm{pH}$ quando descontada a acidez trocável extraida por sais não tamponados (BHUMBLA \& MC LEAN, 1965; MC LEAN et alii, 1965 e COLEMAN \& THOMAS, 1967). No Brasil esta determinação é feita com acetato de cálcio tamponado a pH 7,0, conforme método descrito por VETTORI (1969). 
Em solo que não tenha sofrido lixiviação por sais tamponados, a acidez extraida por sal tamponado inclui também as formas trocáveis da acidez, sendo por isso denomina da acidez total (COLEMAN \& THOMAS, 1967), e acidez potencial (KINJO, I 983$)$.

2.2* Propriedades dos solos que influem na sua necessidade de calcário

Muitas propriedades dos solos associadas com sua acidez, e várias combinações destas propriedades, tem sido utilizadas para estimar a necessidade de calcário dos so los*

KEENEY \& COREY (I 963) trabal hando com 26 solos ácidos de Wisconsin (EUA), compararam várias propriedades dos solos com a necessidade de calcário para elevação do $\mathrm{pH}$ dos mesmos ao valor 6,5 por incubação. A matéria orgânica foio con tribuinte mais importante nesta necessidade, sendo que o alumínio trocável e a fração argila não influenciaram-na signifi cativamente, provavelmente pelos baixos teores encontrados na queles solos:

PRATT (I96I), à semel hança dos resultados obtidos por COLEMAN et alii (1959) em solos do noroeste dos EUA, mostrou que em solos da Califórnia, a CTC dependente do pH, isto é, CTC a pH 8,2 - CTC a pH do solo obtida pelo $\mathrm{KCl}$, ti nha valores equivalentes a acidez dependente do $\mathrm{pH}$, sendo a carga permanente aproximadamente igual a soma dos cátions metálicos básicos mais o alumínio trocável. Além disso, os re sultados mostraram que as quantidades de $\mathrm{CaCO}_{3}$ (em e.mg) re queridas para saturar o solo (ponto de inflexão) menos a acidez trocável eram iguais a CTC dependente do pH. Embora MC 
LEAN et alii (1965) tenham evidenciado que o critério para carga permanente da CTC, tomada como a soma dos cátions metál i cos deslocada pelo $\mathrm{KCl}$ possa ser superestimada se não se le va em conta o $\mathrm{pH}$ do adsorvente quando a lavagem com $\mathrm{KCl}$ se inicia, os estudos de PRATT (1961) mostraram a estreita correlação existente enţre a CTC dependente do $\mathrm{pH}$ e a necessidade de calcário dos solos.

Trabal hos realizados por ROSS et al i i (1964) em nove solos de Michigan (EUA), comparando propriedades físicas e químicas dos solos com a necessidade de calcário para pH 6,8 obtida por incubação, mostraram que esta correl acionou-se significativamente com a capacidade de troca de cátions, obti da a $\mathrm{pH} 7,0$, conteúdo de matéria orgânica, fração argila e hi drogênio trocável, este definido pelos autores como a diferen ça entre a CTC determinada a $\mathrm{pH} 7,0$ e a soma de bases trocá veis dos solos. KAMINSKI (1974) fez observações semelhantes em 34 solos ácidos do Rio Grande do Sul.

MC LEAN et alii (1 965) mostraram a influência da aplicação de calcário e destruição da matéria orgânica na CTC. Constataram marcante incremento na CTC obtida pelo $\mathrm{KCI} I \mathrm{~N}$ pela calagem, sendo que a destruição da matéria orgânica causava pronunciado decréscimo nesta mesma CTC somente nos solos que haviam sofrido calagem. A CTC ceependente do pH teve drástica redução nos solos com maiores níveis de calagem, nos quais a matéria orgânica estava presente. Sua destruição com $\mathrm{H}_{2} \mathrm{O}_{2}$ causava decréscimo substancial nesta mesma CTC somente nos solos com menores niveis de calagem. Os autores mostraram que a matéria orgânica é a principal responsável pelo compo nente da acidez desenvolvido a al to $\mathrm{pH}$, bem como que as mudan ças na CTC pela calagem e destruição da matéria orgânica pare cem resultar da ativação ou inativação de sítios de troca da 
matéria orgânica inicialmente bloqueados pelo aluminio. HELLING et alii (1964) e MC LEAN \& OWEN (1970) estudaram a con tribuição da matéria orgânica e da argila para a CTC, em diferentes níveis de $\mathrm{pH}$, tendo observado que a contribuição da ar gila para a CTC dependente do pH era maior a pH mais baixo, sendo a matéria orgânica o contribuinte de maior importância a $\mathrm{pH}$ mais el evado.

Estudos realizados por PIONKE et alii (1968)com 126 solos ácidos de Wisconsin (EUA) mostraram que as princi pais propriedades dos solos que influiram na necessidade de calcário, incluem, por ordem de importância, os sítios dependentes do $\mathrm{pH}$ da matéria orgânica, o alumínio acídico não trocável, o alumínio trocável e os sítios dependentes do $\mathrm{pH}$ das argilas.

COLEMAN \& THOMAS (1967) sugerem que a necessidą de de calcário dos solos dependeria da acidez trocável, devida principalmente aos íons monômeros de Al, até pH em torno de 5,5. Acima destes valores teriam maior influencia os grupos funcionais ácidos da matéria orgânica e os polímeros de hidró xidos de alumínio, reforçando o importante papel do alumínio, em suas diversas formas, para a acidez dos solos.

\subsection{Métodos de recomendação de cal agem}

\subsubsection{Métodos que utilizam soluções tamponadas}

Um breve histónico acerca do desenvol vimento dos métodos de determinação da necessidade de calcário foi relatá da por PEECH \& BRADFIELD (1948). Segundo os autores, dentre os métodos envolvendo o uso de hidróxidos, Veitch em 1902, util i zava o hidróxido de cálcio e fenolftaleina na determinação do 
hidrogênio trocável, encontrando altos valores para o mesmo pelo fato de que o $\mathrm{pH}$ do ponto de viragem do indicador era muito elevado. Dun, em 1943 empregando o mesmo reagente, utilizou titul ação potenciométrica com eletrodos de vidro na medição da acidez. Hopkins utilizou um sal de ácido forte, o $\mathrm{KNO}_{3}$, entretanto este sal não deslocava todo o hidrogênio tro cável, e os resultados obtidos para o mesmo eram baixos.

Referem ainda que um método envolvendo o uso de acetato de cálcio foi descrito por Jones, em 1913, mas não evidenciava bons resultados em sol os muito ácidos. Schofield, em 1933 propôs a utilização de uma solução de paranitrofenol, parcialmente neutral izada pelo hidróxido de cálcio, para a de terminação do hidrogênio trocável. Entretanto, os resultados obtidos eram mais baixos do que os obtidos pelo método propos to por Mehlich, em 1938, que utilizava uma solução tampão de trietanolamina juntamente com acetato de bário.

BROWN (1943) propôs um método para determinação do hidrogênio trocável, baseado na deflexão produzida no $\mathrm{pH}$ de uma solução tamponada de acetato de amônio IN a $\mathrm{pH} 7,0$ quando da mistura do solo com a solução. A acidez a ser neutralizada era obtida atravéz do pH de equilíbrio de uma suspensão solo tampão na relação $1: 10$, sendo conhecida a curva de titulação potenciométrica do tampão com ácido acético. Apresentava entretanto, o inconveniente de produzir uma defle xão muito pouco acentuada no pH da suspensão, em virtude do al to poder tamponante da solução empregada*

Mais tarde WOODRUFF (1948), baseado no trabalho de BROWN (1943), substituiu a solução tampão de acetato de amônio por uma solução contendo paranitrofenol, óxido de magné sio e acetato de cálcio tamponada a pH F,0. A depressão produ 
zida no $\mathrm{pH}$ da solução tampão quando da mistura com o solo era I inear até $\mathrm{pH}$ 6,0, e para cada 0,1 unidade de decréscimo no pH da suspensão, eram necessários 1 exm $\mathrm{CaCO}_{3} / \mathrm{lO0g}$ de solo para neutralizar a acidez e elevar o $\mathrm{pH}$ do solo a uma faixa entre 6,0 e 6,5 .

No entanto Mc Lean et alii, citados por SCHOEMA KER et alii (1961) observaram que o método tampão de WOODRUFF (1948) não fornecia boa indicação da necessidade de calcário para elevar o $\mathrm{pH}$ de certos solos de Ohio a um nível adequado ao desenvolvimento das plantas. Maior discrepância ocorria em solos com mais alto teor de alumínio trocável presente.

Com base nestas observações SCHOEMAKER et al i i

(1961) desenvolveram um novo método tampão, conhecido como SMP, que utiliza, além do paranitrofenol e acetato de cálcio, cromato de potássio, trietanolamina e cloreto de cálcio, ajustados a pH 7,5. Esta solução produzia, quando em contato com o solo, uma depressão linear muito próxima no $\mathrm{pH}$ com o decrésci mo da acidez do solo. Os autores relatam que embora o poder tamponante desta solução seja mais fraco do que a solução empregada por Mehlich e Woodruff, por outro lado faz com que a mudança no pH ocorra' rapidamente quando os ácidos do solo rea gem com ela, e a amplitude de valores obtida seja mais ampla $(4,8$ a 6,8-aproximadamente).

PEECH et alii (1962) modificaram o método origi nalmente proposto por Mehlich, em 1938, utilizando uma solu ção mais diluida de trietanolamina e cloreto de bário, porém utilizando ainda a titulação como forma de medida da acidez. Uma forma simplificada deste método, destinada a determinação da necessidade de calcário dos solos ácidos foi mais tarde descrita pelo mesmo autor (PEECH, 1965a). 
VETTORI (1948) descreve um método de determinação da necessidade de calcário dos solos baseado no uso de uma solução de acetato de cálcio IN, tamponada a pH 7,0. A quantidade de calcário a ser utilizada seria equivalente ao valor necessário para neutralizar a acidez extraída por esta solução. Atualmenţe $10 \mathrm{~g}$ de solo são agitados com $150 \mathrm{ml}$ da sol ução citada, sendo a determinação do H+Al extraido feita por titulação com $\mathrm{NaOH}_{r^{*}}$ Os valores obtidos são acrescidos em $10 \%$, para compensar supostas deficiências na extração (VETTORI, 1969).

Outro método utilizando solução tamponada foi descrito por ADAMS \& EVANS (1962), e testado para solos do AI abama (EUA), de baixa CTC. A solução consistia de uma mistura de paranitrofenol, ácido bórico, cloreto de potássio e hidróxido de potássio, tamponada a $\mathrm{pH} 8,0 \pm 0,1$. Os autores encontraram alta correlação entre os valores de acidez obtidos pelo tampão, quando comparados com a acidez trocável obtida pelo $\mathrm{NH}_{4} \mathrm{OAC} \mathrm{IN}$, tomado como padrão. Ótimos resultados foram obtidos quando compararam a necessidade de calcário recomendada pelo método proposto com a necessidade calculada para levar o solo a uma insaturação de bases (base insaturation) de 25\%, que corresponderia aproximadamente a um $\mathrm{pH}$ em água de 6,5. Variações entre os dois métodos resultaram numa dife rença de recomendação menor do que 500 libras/acre em 97\% das 348 amostras estudadas.

Recentemente YUAN (1974) propôs um novo método de recomendação de calagem, baseado no conceito de duplo tam pão. Propôs a utilização de duas soluções tamponadas, de mes ma concentração, consistindo de tris, imidazol, $\mathrm{K}_{2} \mathrm{CrO}_{4}$, pyridina e cloreto de cálcio, uma tamponada a $\mathrm{pH} 7,0$ e outra a 
pH 6,0, como forma de medir a acidez. Para cada 0,1 emg de ácido que reage com as soluções ocorre a redução de 0,1 unida des de $\mathrm{pH}$. Determina-se a capacidade tampão dos solos $(\alpha)$ pel a fórmula: $\alpha=\left(d_{1}-d_{2}\right) /\left(h_{1}-h_{2}\right)$, onde $d_{1}$ e $d_{2}$ são valores da acidez determinados pelo decréscimo do $\mathrm{pH}$ das suspen sões em contato cam os tampões a pH 7,0 e 6,0, e $h_{1}$ e $h_{2}$ são os valores do $\mathrm{pH}$ de equilíbrio dos mesmos tampões. A necessidade de calcário ér determinada pela fórmula:

$$
N C=d_{1}+\alpha\left(h-h_{1}\right) \text {, onde } h \text { constitui o valor }
$$

de $\mathrm{pH}$ desejado: 0 método proposto, testado em 20 solos arenosos da Flórida (EUA), mostrou que as quantidades recomendadas foram altamente correlacionadas e comparáveis com as obtidas pelo método de Mehlich, de 1948 e com a incubação com Ca(OH)2*

\subsubsection{Método do alumínio trocável}

A utilização dos valores de alumínio trocável obtidos pela extração com solução de sais não tamponados como critério para determinação da necessidade de calcário dos solos, teve divulgação a partir do trabalho de COLEMAN et alii (1958), ao qual seguram-se os de KAIMPRATH $(1967,1970)$ * 0 método preconiza que a quantidade de calcá rio a ser adicionada deve ser suficiente para neutralizar o alumínio trocável extraído com KCl (KAMPRATH, 1967). Os valo res de alumínio trocável, assim obtidos, são multiplicados por um fator, que varia de 1 a 3 , dando a indicação da quantidade de calcário a ser aplicada no solo (SOUzA et alii, 1980): Trabalhos realizados por FREITAS et ali i (1968) e TOBON \& LEON (1971), mostram que as quantidades de calcário re comendadas por esse método são pouco efetivas para atingir - 
se um $\mathrm{pH}$ preestabelecido, sendo porém eficaz na redução do teor de Al trocável a níveis não tóxicos. KAMPRATH (1970) su gere o emprego do fator 1,5 para atingir uma saturação com alumínio igual, ou inferior a $15 \%$ nos solos estudados (Oxissol e Ultissol). Admite ainda que um fator 2 poderá ser utilizado para culturas mais sensíveis ao alumínio trocável.

A difusão deste método no país ocorreu a partir da divulgação do Programa Internacional de Anál ise de So Io:(CATE, 1965), onde a quantidade de corretivo indicada era: $1,5 \times$ emg $\mathrm{Al}^{3+} / 1009$ TFSA $=t \mathrm{CaCO}_{3} /$ ha. A partir de então o método sofreu várias adaptações e modificações, porém consti tui - se ainda num dos principais métodos de recomendação de cal agem no Brasil.

\section{$2 \approx 3: 3$. Método da saturação de bases dos solos}

Um dos mais antigos métodos de recomendação de calcário empregados no país foi proposto por CATANI \& GALLO (1955) e utilizava a relação entre o pH e a saturação de bases do solo. Trabalhando com 85 amostras do estado de São Paulo, os autores obtiveram a relação entre estas duas variá veis, dada pela equação: $\mathrm{pH}=0,03176 \mathrm{v} \%+4,288$, com $r=$ 0,947, tornando possível determinar o valor $\mathrm{V} \%$ da amostra apenas pela leitura do $\mathrm{pH}$ em água da mesma. Admitindo-se portanto, com base na equação proposta, uma saturação de bases de $70 \%$ como a ideal para se atingir um pH 6,5, e conhecendose também a acidez potencial $\left(\mathrm{H}^{\circ}+\mathrm{Al}^{3+}\right)$ extraida com acetato de cálcio IN a pH 7,0, é possível determinar a quantidade de calcário a ser aplicada a partir da seguinte equação: 


$$
\begin{aligned}
N C= & H \frac{\left(V_{2}-V_{1}\right)}{100-V_{1}}=t \mathrm{CaCO}_{3} / \text { ha, onde: } \\
H= & \text { emg } H / 1009 \text { TFSA, obtido por extração com aceta- } \\
& \text { to de cál cio IN, a pH 7,0. } \\
V_{2}= & \text { Saturação de bases para atingir um pH de } 6,5 \\
& (70 \%) \\
V_{1}= & \text { Saturação de bases atual do solo, obtido da lei- } \\
& \text { tura do pH e fazendo a conversão na equação ou - } \\
& \text { tabelá. }
\end{aligned}
$$

Trabalhos posteriores real izados por RAlJ et al ii (1968) mostraram entretanto relação diferente entre o $\mathrm{pH} \times$ saturação de bases para solos do mesmo estado, o que le vou CATANI \& ALONSO (1969) a considerar a elevação do valor $V$ a $85 \%$, como mais adequado para se atingir um $\mathrm{pH} 6,5$, quando testou o método proposto.

Nas recomendações de calagem de rotina, o méto do de CATANI \& GALLO (1955), apresenta como principal des vantagem o fato de exigir a determinação da acidez potencial, que é feita por titulação. Entretanto RAlJ et alii (1979) mostraram a possibilidade de determinar esta acidez a partir de leituras potenciométricas do $\mathrm{pH}$ de equilíbrio da solução tampão SMP com o solo, pois observaram excel ente correlação entre os valores de $\mathrm{pH}$ da suspensão solo:água:tampão SMP ( $\mathrm{pH}$ SMP) e os valores de $\left(\mathrm{H}^{\circ}+\mathrm{Al}^{3+}\right)$ obtidos pelo método do acetato de cálcio em solos do estado de São Paulo. Quaggio \& Raij (1982) citados por QUAGGIO (1983b), num trabal ho posterior, trabalharam com uma população de solos mais ampla da quele estado e obtiveram nova correlação neste sentido, que permite a obtenção de valores de $\left(\mathrm{H}^{\circ}+\mathrm{Al}^{3+}\right)$ de até $30 \mathrm{e} \mathrm{mg/}$ $100 \mathrm{~cm}^{3}$ de terra apenas pela l eitura do $\mathrm{pH}$ SMP. Deste modo, a 


$$
\begin{aligned}
& \text { necessidade de calcário pode ser obtida pela fórmula: } \\
& \mathrm{NC}\left(\mathrm{t} \mathrm{CaCO}_{3} / \mathrm{ha}\right)=\frac{\operatorname{CTC}\left(\mathrm{V}_{2}-\mathrm{V}_{1}\right)}{100} \text {, onde: } \\
& N C=\text { necessidade de calcário } \\
& \text { CTC = capacidade de troca de cátions, obtida da soma } \\
& \text { das bases trocáveis, acrescida do teor de } \\
& \left(\mathrm{H}^{0}+\mathrm{Al}^{3+}\right) \text { obtidos pela leitura do } \mathrm{pH} \text { SMP. } \\
& v_{1}=\text { saturação de bases atual do solo, obtida de } \\
& \frac{\mathrm{S} \times 100}{\mathrm{CTC}} \\
& v_{2}=\text { saturação de bases desejada. }
\end{aligned}
$$


3. MATERIAL E MÉTODOS

3.1. Solos estudados

Utilizou-se no presente trabalho, 23 amostras de terra, representando 13 séries de solo do município de $\mathrm{Pi}$ racicaba, SP, sendo 12 amostras da camada superficial e II amostras de horizontes de subsuperfície, cuja identificação encontra-se na tabela I. Procurou-se efetuar a coleta em locais próximos da área em que o perfil de cada série foi descrito por ocasião da elaboração da Carta de Solos do Município de Piracicaba (RANZANI et alii, 1966).

3.2. Preparo das amostras

Após a coleta, as amostras de terra foram secas ao ar, destorroadas e passadas em peneira com malha de $2 \mathrm{~mm}$ de abertura. Cada uma das amostras foi subdividida em 6 (seis) subamostras com 500 gramas, sendo uma delas separada para a caracterização química e física. Nas 5 (cinco) suba- 
Tabela I. I dentificação das amostras de terra estudadas

\begin{tabular}{|c|c|c|c|c|}
\hline $\begin{array}{l}\text { Amos } \\
\text { tra } \\
\text { no }\end{array}$ & $\begin{array}{l}\text { Hori- } \\
\text { zonte }\end{array}$ & $\begin{array}{l}\text { Profun } \\
\text { di da de } \\
(\mathrm{cm})\end{array}$ & Nome da Série & Classificação \\
\hline 1 & c & $40-80$ & Cruz Alta & Areia Quart́zóza Podzólica \\
\hline 2 & Ap & $0-20$ & Gibóia & Podzólico Vermel ho Amarelo \\
\hline 3 & $A_{3} / B_{1}$ & $30-50$ & Gibóia & Podzól ico Vermel ho Amarelo \\
\hline 4 & Ap & $0-20$ & Saltinho & Podzól ico Vermel ho Amarelo \\
\hline 5 & $\mathrm{~B}_{2}$ & $60-100$ & Saltinho & Podzólico Vermel ho Amarelo \\
\hline 6 & $A$ & $0-30$ & Ponte Funda & Podzól ico Vermel ho Amarelo \\
\hline 7 & B & $60-80$ & Ponte Funda & Podzól ico Vermel ho Amarelo \\
\hline 8 & $A p$ & $0-20$ & Ibitiruna & Podzól ico Vermel ho Amarelo \\
\hline 9 & $\mathrm{~B}_{2}$ & $60-90$ & lbitiruna & Podzól ico Vermel ho Amarelo \\
\hline 10 & $A p$ & $0-20$ & Anhumas & Cambissolo \\
\hline 11 & $\mathrm{~B}_{2}$ & $40-60$ & Anhumas & Cambissolo \\
\hline 12 & $A$ & $0-20$ & Godinhos & Podzól ico Vermel ho Amarelo \\
\hline 13 & B & $70-100$ & Godinhos & Podzól ico Vermel ho Amarelo \\
\hline 14 & Ap & $0-20$ & Quebra Dente & Podzólico Vermel ho Amarelo \\
\hline 15 & $\mathrm{~B}_{2}$ & $80-120$ & Quebra Dente & Podzól ico Vermel ho Amarelo \\
\hline 16 & $A p$ & $0-25$ & Sertãozinho & Latossolo Vermel ho Amarelo \\
\hline 17 & B & $30-60$ & Sertãozinho & Latossolo Vermel ho Amarelo \\
\hline \multirow[t]{2}{*}{18} & $A p$ & $0-30$ & Paredão & \\
\hline & & & Vermel ho & Latossolo Vermel ho Amarelo \\
\hline 19 & $A p$ & $0-20$ & Guam ium & Latossolo Vermel ho Escuro \\
\hline 20 & $A p$ & $0-20$ & Form igue iro & Hidromórfico \\
\hline 21 & $\mathrm{Bg}$ & $40-60$ & Form igue iro & Hidromórfico \\
\hline 22 & $A p$ & $0-20$ & Artemis & Podzól ico Vermel ho Amarelo \\
\hline 23 & $\mathrm{~B}_{2}$ & $30-60$ & Artemis & Podzól ico Vermel ho Amarelo \\
\hline
\end{tabular}


mostras restantes, para cada um dos solos, foram aplicados os tratamentos, conforme será descrito a seguir.

\subsection{Tratamentos utilizados}

As 5. (cinco) subamostras de cada um dos solos foram àplicadas doses crescentes de carbonato de cálcio puro, equivalentes ao necessário para neutralizar $0 ; 0,25 ; 0,5 ; 1,0$ e 1, 5 vezes o teor de hidrogênio mais alumínio, determinados por extração com solução de acetato de cálcio IN, tamponada a pH 7,0. Para efeito de cálculos, foi considerada a massa de um hectare como sendo de 2000 tonel adas, sendo doses correspondentes em t/ha aplicadas nas subamostras de 500 gramas. As doses de carbonato de cálcio foram homogeneizadas nos tratamentos, sendo os mesmos colocados em sacos plásticos, re cebendo umidade correspondente a $60 \%$ da capacidade máxima de retenção. Os sacos plásticos foram então fechados e os solos mantidos em incubação por um período de 180 dias, durante o qual foram abertos por três vezes, para revolvimento das amostras e controle da umidade por pesagem. Ao final deste pe ríodo, as amostras foram novamente secas ao ar, destorroadas, moidas e utilizadas para as determinações analíticas.

\section{4* Determinações analíticas}

$$
3.4 .1 . \mathrm{pH}
$$

$0 \mathrm{pH}$ foi determinado potenciometricamente, uti I izando-se um pH - metro, marca Metrohm - E 516.

Em todas as amostras e tratamentos, foram fei- 
tas determinações de $\mathrm{pH}$ em água, na relação $1: 1$, pH em solução $0,01 \mathrm{M}$ de $\mathrm{CaCl}_{2}$, rel ação $1: 1,5$, ambos com tempo de repouso de I (uma) hora, e pH após a adição da solução SMP (SCHOEE MAKER et al ii, 1961) modificada segundo MIELNICZUK et alii (1969), na relação solo:água: solução SMP de $1: 1: 0,5$, e tempo de repouso de 20 minutos.

\subsubsection{Alumínio trocável}

O aluminio trocável foi extraído com solução de $\mathrm{KCl}$ IN e determinado por titulação com hidróxido de sódio $0,02 \mathrm{~N}$, conforme metodologia sugerida por CATANI \& JACINTHO (1974).

\subsubsection{Hidrogênio mais alumínio}

Os valores de hidrogennio mais al umínio $\left(\mathrm{H}^{\circ} \mathrm{Al}^{3+}\right.$ ) foram obtidos por extração com solução de acetato de cálcio IN, tamponada a pH 7,0 e titulação com hidróxido de sódio, conforme método descrito por CATANI \& JACINTHO (1974).

\subsubsection{Cálcio mais magnésio trocáveis}

O cálcio mais magnésio ( $\mathrm{Ca}+\mathrm{Mg})$ trocáveis foram extraídos com solução de $\mathrm{KCl}$ IN, sendo a titulação feita com solução de EDTA, de acordo com metodologia de CATANI \& JACI NTHO ( 1974 ).

3.4.5. Potássio e fósforo extraíveis 
0 potássio e o fósforo foram extraídos com $\mathrm{H}_{2} \mathrm{SO}_{4} \mathrm{O}, 05 \mathrm{~N}$ sendo o potássio determinado por fotometria de chama e o fósforo por fotocolorimetria, conforme metodologia descrita por CATANI \& JACINTHO (1974).

\subsubsection{Matéria orgânica}

Os teores de matéria orgânica foram obtidos por via úmida, determinando-se os teores de carbono orgânico, atre vésde sua oxidação com solução de $\mathrm{K}_{2} \mathrm{Cr}_{2} \mathrm{O}_{7} \mathrm{IN}$ em meio ácido, e dosagem do excesso de $\mathrm{K}_{2} \mathrm{Cr}_{2} \mathrm{O}_{7}$ por titulação com solução de sulfato ferroso amoniacal, utilizando como indicador sulfonato de bário, conforme metodologia sugerida por MALAVOLTA \& COURY (1954). O teor de matéria orgânica foi calculado multip! icando-se a \% de carbono orgânico pelo fator 1,724.

3.4.7. Cálculo da soma de bases, saturação em bases e capacidade de troca de cátions

A soma de bases (S) foi calculada pelo somatório de valores de cálcio, magnésio e potássio trocáveis, sendo expressa em e.mg/l00g de TFSA.

A saturação em bases (valor V) foi calculada valiando-se a participação da soma das bases trocáveis em rel ação a capacidade de troca de cátions determinada ao pH 7,0, multiplicada pelo valor 100, segundo a fórmula:

$$
\begin{aligned}
\mathrm{V} \%=\frac{\mathrm{S}}{\mathrm{CTC}} \times 100 \\
\text { A capacidade de troca de cátions efetiva foi } \underline{\mathrm{a}}
\end{aligned}
$$
valiada pela soma das bases trocáveis (S) acrescida dos 
teores de alumínio trocável, sendo expressa em e.mg/l00g de TFSA.

A capacidade de troca de cátions determinada a pH 7,0 (CTC à $\mathrm{pH} 7,0)$ foi obtida acrescendo-se à soma de bases $(S)$ os teores de hidrogênio mais alumínio $\left(H^{\circ}+\mathrm{Al}^{3+}\right)$, sen do expressa em e.mg/l00g de TFSA.

\subsubsection{Análise granulométrica}

A areia total foi determinada por peneiramento das amostras, após determinação dos teores de argila pelo mé todo internacional da pipeta, modificado segundo VETTORI (1969); Os teores de silte foram calculados por diferença.

3.5. Métodos de recomendação da necessidade de calcário testados

A necessidade de calcário foi avaliada por qua tro métodos: alumínio trocável, acetato de cálcio, SMP e saturação de bases. 0 método da incubação com doses crescentes de calcário foi tomado como padrão para comparação com os de mais métodos.

3.5.1. Método do alumínio trocável

As doses de carbonato de cálcio por este método foram calculadas levando-se em conta o teor de aluminio,e cál cio mais magnésio trocáveis, utilizando-se as seguintes fórmulas: 


$$
\begin{aligned}
& N C(t / h a)=A^{3+}(\text { e.mg/lO0g TFSA }) \times 1,5 \text { ou } \\
& N C(t / h a)=Y-(\text { e.mg Ca }+M g / I 00 g \text { TFSA }) \text {, onde: } \\
& Y=2 \text { para solos arenosos com menos de } 2 \% \text { de M. } 0 . \\
& Y=3 \text { para os demais solos }
\end{aligned}
$$

A recomendação foi feita sempre tendo por base a maior dose encontrada.

3.5.2. Método do acetato de cál cio

A quantidade de carbonato de cálcio a ser aplicada por este método foi obtida das equações de regressão cal culadas da relação entre as quantidades de carbonato de cál cio obtidas pelo método de incubação e os teores de $\left(H^{\mathbf{O}}+\mathrm{Al}^{3+}\right)$ determinados conforme método descrito no item 3.4.3.

\subsubsection{Método SMP}

Utilizou-se neste caso o método SMP modificado por MIELNICZUK et alii (1969), que usa o dobro da quantidade de reagentes por litro de solução e $1 / 4$ do volume da solução tampão em relação ao método original, sugerido por SCHOEMA KER et alii (1961).

\subsubsection{Método da saturação em bases}

A necessidade de calcário por este método é baseada no trabal ho de CATANI \& GALLO (1955) com as modifica ções propostas por QUAGGIO (1983) sendo a dose a ser recomen dada obtida pela fórmula: 


$$
\begin{aligned}
& \text { NC }(t / h a)=\frac{\operatorname{CTC}\left(V_{2}-V_{1}\right)}{100} \text { onde: } \\
& N C=\text { necessidade de calcário com PRNT }=100 \% \text {, em } t / h a x \\
& \text { CTC = capacidade de troca de cátions a } \mathrm{pH} 7,0 \text {, em } \\
& \text { e.mg/l 00g TFSA } \\
& V_{2}=\text { saturação em bases a ser atingida: } \\
& v_{1}=\text { saturação em bases atual do solo. } \\
& \text { A CTC, neste caso é obtida por método estimati } \\
& \text { vo, acrescendo-se à soma de bases, os teores de }\left(\mathrm{H}^{\mathrm{O}}+\mathrm{Al}^{3+}\right) \\
& \text { obtido pela leitura direta do pH SMP, através de prévia cali- }
\end{aligned}
$$
bração entre os dois parâmetros. 


\section{RESULTADOS E DISCUSSÃO}

4.1. Caracterização geral dos solos estudados

A caracterização física e química das amostras encontra-se na tabela 2. As análises químicas evidenciam para a grande maioria dos solos um baixo teor de matéria orgânica, cujo intervalo de variação situou-se entre 0,31 e 3,52\%. Teores mais elevados, como era esperado, ocorreram nos horizontes superficiais das amostras. Dentro destes, valores mais al tos foram encontrados nos solos com maior conteúdo de argila. Os teores de cálcio mais magnésio $(C a+M g)$ tiveram maior amplitude de variação, situando-se entre 0,7 a 6,1 e.mg/lo0g de TFSA, fato semelhante ocorreu com o potássio, que variou de 0,03 a 0,66 e.mg/l00g de TFSA. Os teores de alumínio trocável podem ser considerados elevados, situando-se numa média de I,28 e.mg/lo0g de solo, com variação entre 0,3 a 5,8 exmg/lo0g de solo. 0 índice de saturação com alumínio "m", variou de 9 a 69\%, e os menores valores ocorreram nos níveis de $\mathrm{pH}$ em água mais elevados, excessão feita às amostras superficiais - 


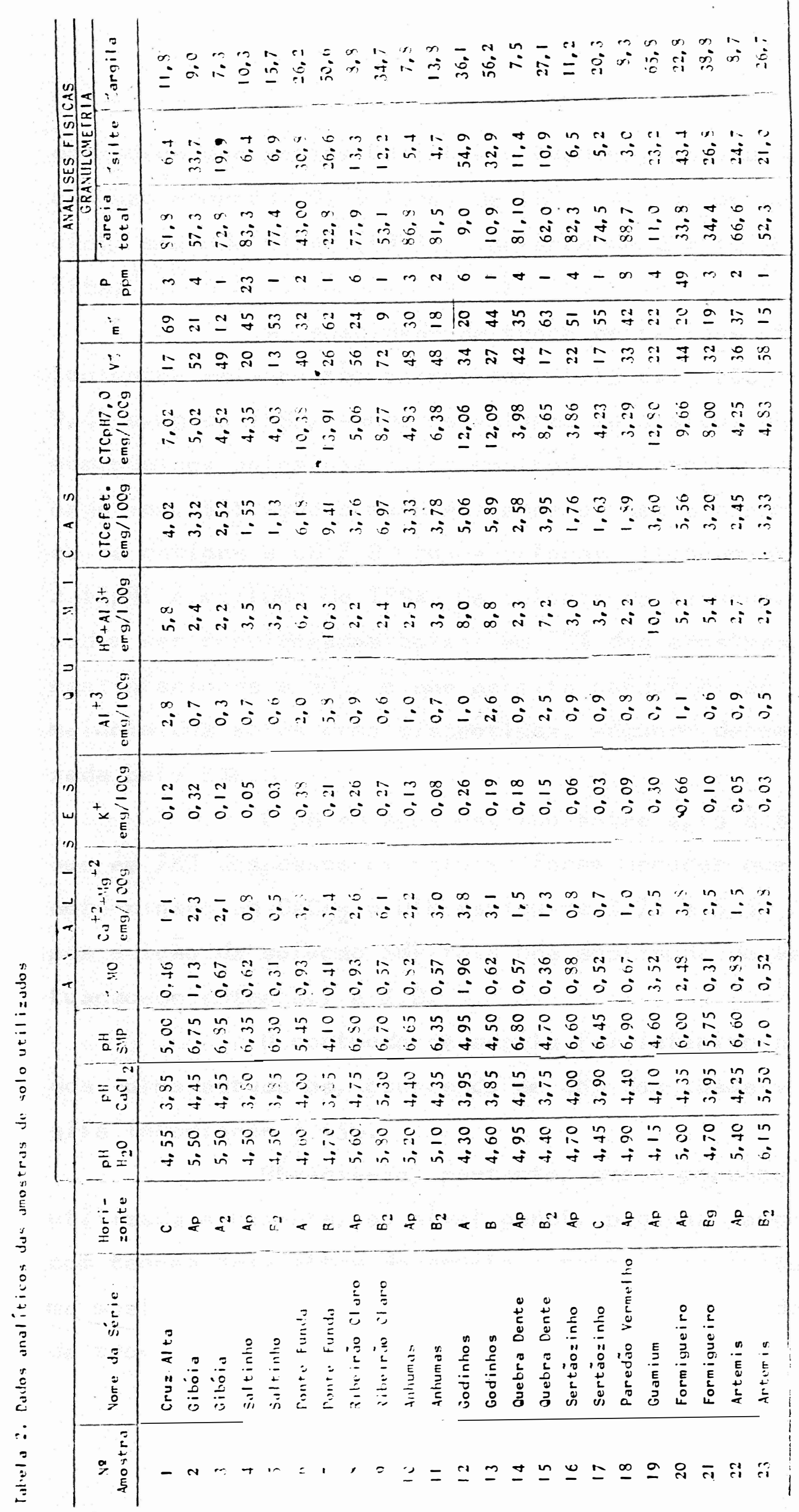


dos solos das séries Godinhos e Guamium, nas quais tal situação näo ocorreu. Os valores de $\left(\mathrm{H}^{\mathrm{O}}+\mathrm{Al}^{3+}\right)$, ou acidez poten cial, segundo KINJO (I983), variaram de 2 a 10,3 e.mg/l00g de TFSA.

A capacidade de troca de cátions efetiva, oscil ou entre valores tão baixos como I,I3 e.mg/lo0g de TFSA até 9, 4.1 e.mg de TFSA, sendo os valores mais altos encontrados co mumente nos solos, com maior conteúdo de argila e/ou matéria orgânica. Situação semel hante ocorreu com a capacidade de tro ca de cátions a $\mathrm{pH} 7,0$, cujos valores situaram-se entre 3,29 à 13,91 e, mg/l00g de TFSA. Os valores de saturação em bases podem ser considerados baixos em 78\% das amostras, com valo res inferiores a 50\%, o que permite caracterizar a grande maioria dos solos como distróficos, segundo denominação utili zada pelo SNLCS.

$0 \mathrm{pH}$ em água oscilou entre 4,15 à 6,15, sendo que em $78 \%$ dos casos os valores foram menores que 5,5:0 $\mathrm{pH}$ determinado em $\mathrm{CaCl}_{2}$ 0,0IN variou de 3,75 à 5,5: $0 \mathrm{pH} \mathrm{lido} \mathrm{a-}$ pós adição da solução SMP tere boa amplitude de variação, situando-se entre 4,1 e 7,0 .

0 conteúdo de argila foi inferior a $35 \%$ em $74 \%$ dos solos estudados, ocorrendo em $48 \%$ dos casos valores de ar gila inferiores a $15 \%$.

Observa-se, portanto, que a população de solos utilizada apresenta, ao nível geral, pequena parcela de solos com teores mais altos de argila e matéria orgânica, assim como mostra, na maioria dos casos, baixos valores de capacidade de troca de cátions. 


\subsection{Incubação dos solos com carbonato de cálcio}

A incubação dos solos com doses crescentes de carbonato de cálcio puro, tem sido utilizada em inúmeros trabalhos como método padrão para comparação da necessidade de calcário com outras métodos (SCHOEMAKER et alii, 1961; FREI TAS et alii, 1968; DEFELIPO et alii, I972; KAMINSKI, 1974).

Os dados de $\mathrm{pH}$ em $\mathrm{H}_{2} \mathrm{O}$ e $\mathrm{pH}$ em $\mathrm{CaCl}_{2}$ permitiram avaliar a evolução do $\mathrm{pH}$ nestas duas soluçães em função do carbonato de cálcio aplicado, obtendo-se deste modo curvas de neutral ização para todas as amostras. A curva de neutral i zação obtida para a amostra número ll é mostrada na figura I, a título de exemplo.

As amostras de números 2, 3, 8, 14, 20 e 22, representando em 5 dos casos o horizonte superficial, mostraram drástica redução do $\mathrm{pH}$ em $\mathrm{H}_{2} \mathrm{O}$ na doze zero dos tratamentos, em relação ao pH em $\mathrm{H}_{2} \mathrm{O}$ determinado antes da incubação. Elas serão referidas doravante com a denominação de "amostras proble ma". Tal situação provavelmente tenha ocorrido devido a deficiência de troca gasosa nos sacos plásticos, proporcionando a cúmulo de $\mathrm{CO}_{2}$, ou devido a produção de sais provenientes da mineral ização da matéria orgânica, conforme ja foi constatado por RAlJ et alii, 1979. A segunda hipótese parece mais provável, tendo em vista que os valores de $\mathrm{pH} \mathrm{em} \mathrm{CaCl}_{2}$ não foram afetados nesta mesma condição, o que seria explicado pela uni formização da concentração sal ina das amostras, minimizando o efeito dos sais, conforme relatado por QUAGGIO (1983a).

As doses de carbonato de cálcio tomadas para efeito de comparação com os métodos testados, bem como para avaliação da relação entre a necessidade de calcário e al gumas 


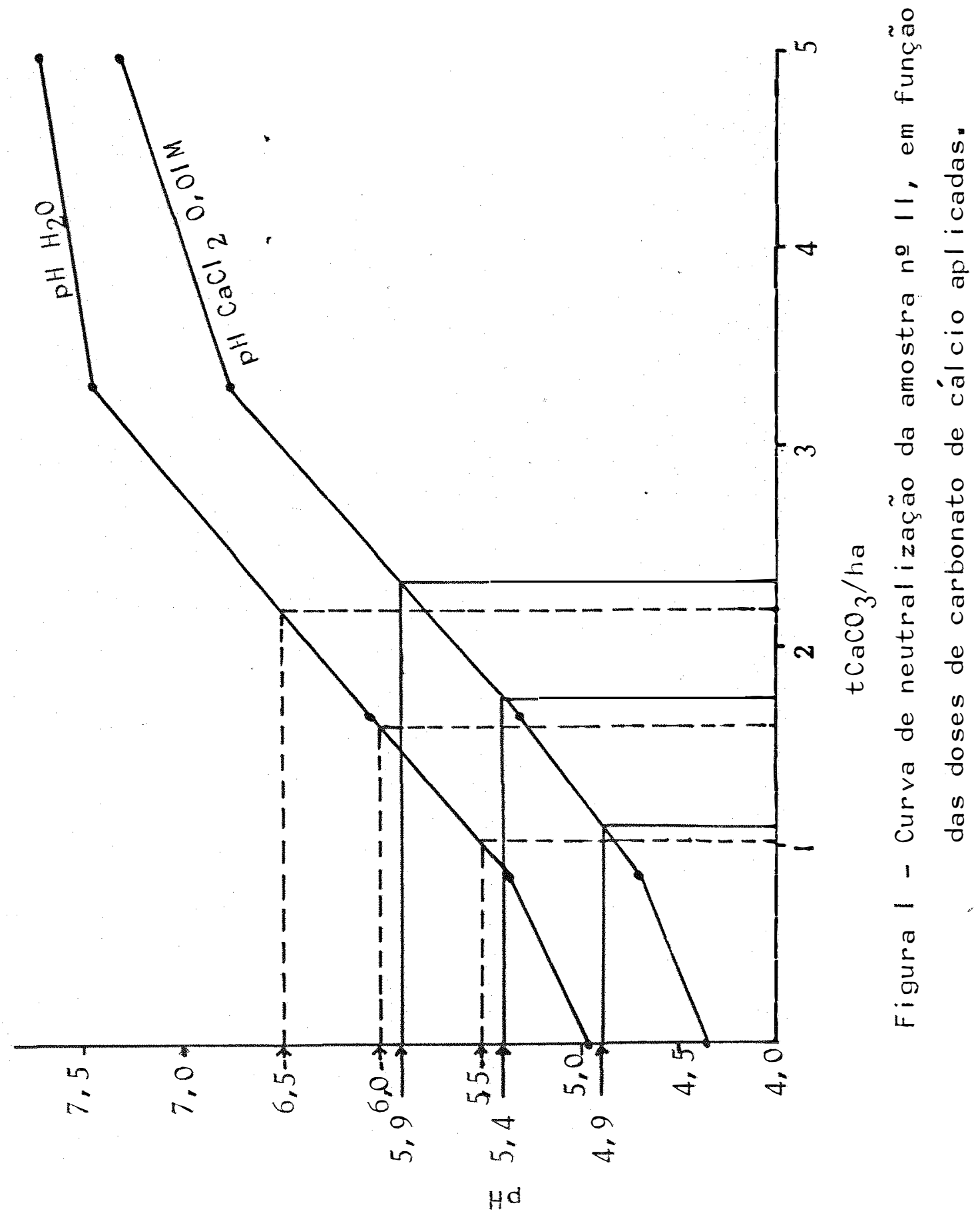


propriedades dos solos, foram obtidas através da interpolação linear das curvas de neutralização dos diversos solos, determinando-se as quantidades de $\mathrm{CaCO}_{3}$ necessárias para el evação do $\mathrm{pH}$ em $\mathrm{H}_{2} \mathrm{O}$ a valores 5,$5 ; 6,0$ e 6,5. As seis amostras anteriormente referidas, foram omitidas nestas comparações, dada a variação ocorriḍ. Foram determinados ainda, igualmente por interpolação linear, as doses de carbonato de cálcio necessárias para el evação, do $\mathrm{pH}$ em $\mathrm{CaCl}_{2}$ aos valores 4,9; 5,4 e 5,9, os quais correponderiam, conforme resultados obtidos no presente trabalho, aos valores de $\mathrm{pH}$ em $\mathrm{H}_{2} \mathrm{O}$ anteriormente cita dos. Estes dados são mostrados na tabel a 3 .

4.3. Rel ação entre o pH em $\mathrm{H}_{2} \mathrm{O}$ e o pH em $\mathrm{CaCl}_{2}$

A relação entre o pH em $\mathrm{H}_{2} \mathrm{O}$ e em $\mathrm{CaCl}_{2}$, nas amostras que não sofreram incubação, encontra-se na figura 2 . Observou-se al ta correlação entre as duas variáveis $(r=0,904)$ sendo que o pH em $\mathrm{CaCl}_{2}$ situou-se, em média, 0,75 unidades de $\mathrm{pH}$ abaixo do valor determinado, para o $\mathrm{pH}$ em $\mathrm{H}_{2} \mathrm{O}$, ocorrendo entretanto, maior concentração de pontos a valores baixos de $\mathrm{pH}$, nas duas determinações, o que deixa dúvidas acerca da ten dência da reta a valores de $\mathrm{pH}$ em $\mathrm{CaCl}_{2}$ acima de 5,5. Efetuou se então nova observação entre o relacionamento das duas variáveis, agora com maior número de amostras, utilizando para tanto as determinações de $\mathrm{pH}$ em $\mathrm{H}_{2} \mathrm{O}$ e $\mathrm{CaCl}_{2}$ feitas nos tratamentos dos solos submetidos a incubação até a $4^{a}$ a dose, exce tuando as seis amostras problema. A equação de regressão obti da entre as duas variáveis, para 68 observações feitas, foi a seguinte:

$$
\begin{aligned}
& y=0,9682 x+0,7517, \text { onde } \\
& x=p^{\prime} \text { em } \mathrm{CaCl}_{2} 0,01 \mathrm{M} \mathrm{e} y=p H \text { em } \mathrm{H}_{2} \mathrm{O} .
\end{aligned}
$$




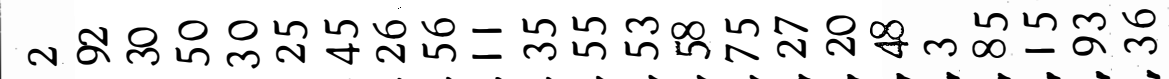

$$
\frac{\pi}{5}
$$$$
\frac{0}{0}
$$$$
\frac{\pi}{0}
$$

๙

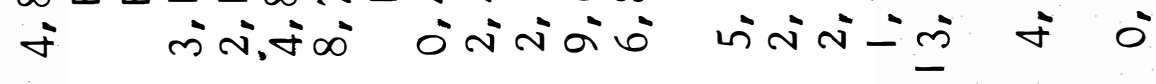




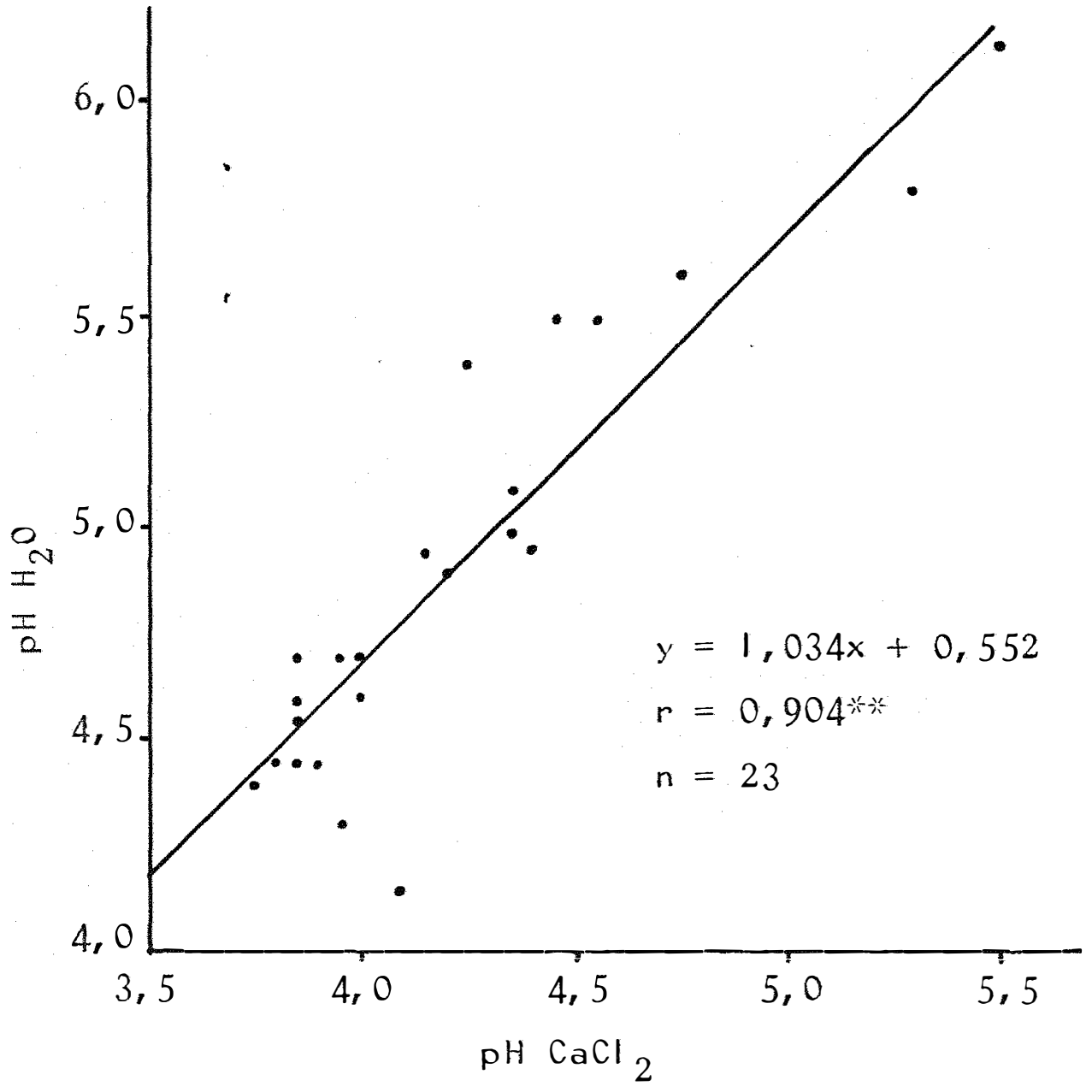

Figura 2 - Relação entre o pH em $\mathrm{H}_{2} \mathrm{O}$ e o pH em solução $0,01 \mathrm{M}$ de $\mathrm{CaCl}_{2}$ para as amostras não incubadas. 


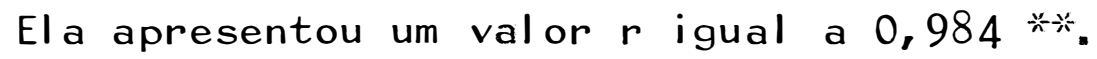

A correlação entre as duas variáveis foi bastan te melhorada pela introdução de maior número de amostras: Resolvendo-se a equação de regressão para alguns valores de $\mathrm{pH}$ em $\mathrm{H}_{2} \mathrm{O}$, observa-se que o $\mathrm{pH}$ em $\mathrm{CaCl}_{2}$ situou-se, em média, 0,6 unidades de $\mathrm{pH}$ aba.ixo do $\mathrm{pH}$ em $\mathrm{H}_{2} \mathrm{O}$. Estes dados aproximam-se daqueles citados em outros trabalhos (PEECH, 1965b; FASSBEN $D E R, 1975)$ e são idênticos aos valores encontrados por QUAGGIO (1983a) para solos do estado de São Paulo, permitindo nos afirmar que a necessidade de cal cário para elevar o $\mathrm{pH}$ em $\mathrm{H}_{2} \mathrm{O}$ à valores de 5,$5 ; 6,0$ e 6,5 , corresponderia a uma el evação do $\mathrm{pH}$ em $\mathrm{CaCl}_{2}$ a valores de 4,9; 5,4 e 5,9 respectivamente. A introdução da leitura do $\mathrm{pH}$ em solução $0,01 \mathrm{M}$ de $\mathrm{CaCl}_{2}$, no presente trabalho, teve por objetivos, ainda, avaliar os possíveis efeitos da produção de sais, provenientes da mineralização da matéria orgânica durante o processo de in cubação dos solos. Esse fenômeno afeta os valores de $\mathrm{pH}$ em $\mathrm{H}_{2} \mathrm{O}$, já comprovado em outros trabalhos (RAlJ et alii, 1979; Mc LEAN et alii, 1966; CURTIN \& SMILLIE, 1983). As leituras potenciométricas, por serem feitas sempre na mesma concentração salina, evitariam o possível efeito de sais contidos nas diferentes amostras. A melhor reprodutibilidade dos resulta dos obtidos pela leitura do $\mathrm{pH}$ em solução salina, citada por PEECH (1965b) FASSBENDER (1975) é outro fator que infuiu na sua inclusão neste trabalho.

4.4. Contribuição da matéria orgânica e da argila para a CTC dos solos

A influência do teor de matéria orgânica e da 
quantidade de argila dos solos na capacidade de troca de cá tions, determinada a $\mathrm{pH} 7,0$, foi avaliada através de regres são linear, tendo-se observado estreita correlação entre es tas variáveis, conforme mostrado nas figuras 3 e 4 .

Estes resultados concordam com as observações de KEENEY \& COREY (1963), quanto a influência da matéria orgâa nica na CTC. Estes autores entretanto, não obtiveram contri buição significativa do teor de argila, diferentemente ocorri do no presente trabalho: RAIJ (1969), trabalhando com vários solos do estado de São Paulo, com ampla variação de CTC, teor de argila e matéria orgânica, mostrou que a matéria orgânica era o constituinte mais importante na delimitação de CTC dos solos, contribuindo com cerca de $74 \%$ dos valores desta. A meIhor correlação obtida no presente trabalho para o teor de ar gila, demonstra a grande contribuição deste parâmetro para a CTC dos solos em questão, e difere ainda dos resultados recen temente obtidos por QUAGGIO (1983) também em solos do estado de São Paulo, o qual não encontrou correlação significativa para o teor de argila como contribuinte da CTC.

A inclusão de grande número de amostras do hor zonte subsuperficial, com baixo teor de matéria orgânica, pode constituir numa explicação para as diferenças encontradas.

4*5* Propriedades dos solos e sua influência na acidez

Associou-se algumas propriedades dos solos que poderiam influenciar na necessidade de calcário dos solos. As equações de regressão, bem como os coeficientes de correlação, obtidos comparando-se estas propriedades com a necessidade de carbonato de cál cio obtida pelo método da incubação para ele- 


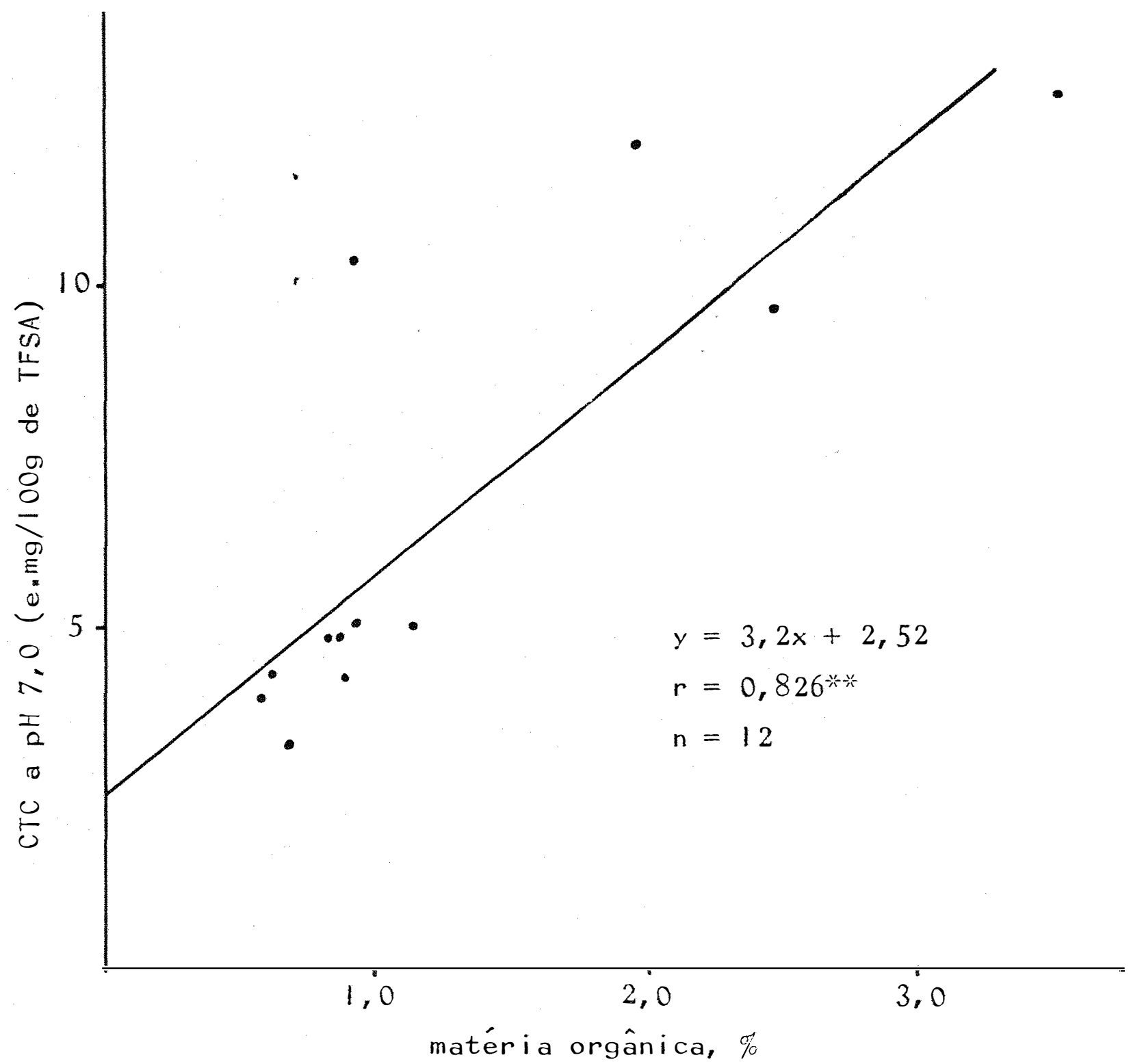

Figura 3 - Rel ação entre a CTC a pH 7,0 e o teor de matéria orgânica nas amostras superficiais. 


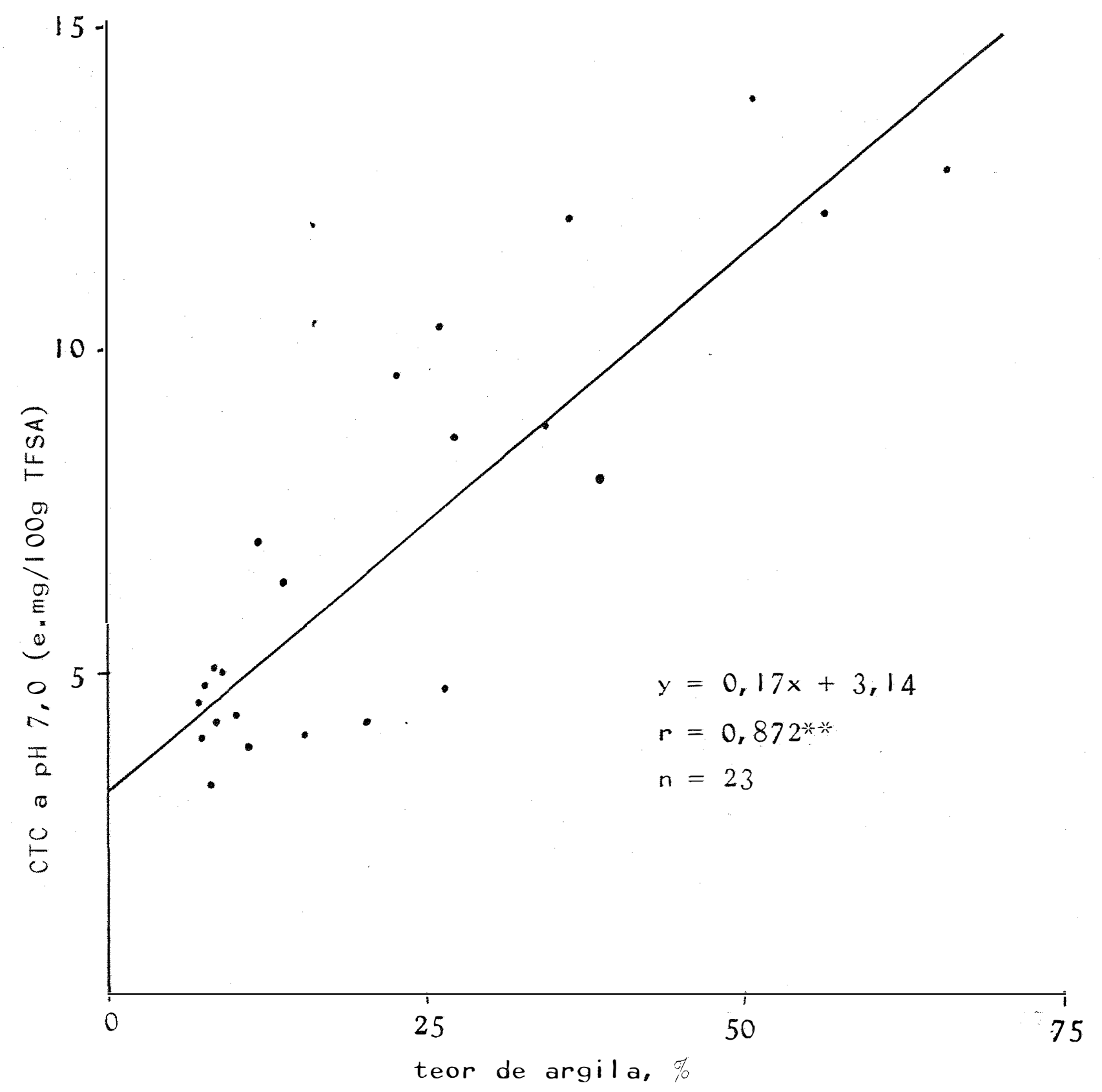

Figura 4 - Relação entre a CTC a pH 7,0 e o teor de argila em todas as amostras. 
var o $\mathrm{pH} \mathrm{H}_{2} \mathrm{O}$ a 6,5 e o $\mathrm{pH}$ em $\mathrm{CaCl}_{2}$ a 5,9 encontram-se na tabe la 4* A melhor correl ação foi obtida com $\left(H^{\circ}+\mathrm{Al}^{3+}\right)$, seguido, respectivamente, pela CTC, teor de argila, e de matéria orgânicax

A capacidade de troca de cátions, determinada a $\mathrm{pH} 7,0$, correlacionou significativamente com a quantidade de carbonato de cálcio necessária para elevação do pH aos dois valores citados.

Isso era esperado, pois os solos estudados apre sentavam baixa saturação de bases, nos quais grande parte da CTC, determinada a $\mathrm{pH} 7,0$, estava preenchida por alumínio tro cável e hidrogênio de ligação covalente. Na medida em que estes dois ions determinam, em grande parte, a necessidade de calcário dos solos, e que seus teores variam de solo para solo, imprimindo uma maior ou menor CTC aos mesmos, o consumo de bases, ou carbonato de cálcio, para neutralizá-los, deve guardar certa proporcionalidade com a CTC determinada a pH 7,0. Na figura 5 está representada a relação entre a CTC a pH 7,0 e a necessidade de carbonato de cálcio para elevar o pH em $\mathrm{H}_{2} \mathrm{O}$ a 6,5. As amostras 9 e 23 representam casos extremos de baixa necessidade de calcário, sendo sua saturação em ba ses originalmente alta: Nestes casos, como observou KAMINSKI (1974), pelo fato de predominarem, na CTC, cátions metálicos básicos, estes não constituem fonte de acidez e portanto não influenciam na necessidade de calcário dos solos. Observa-se ainda, de acordo com a tabela 4, que a correl ação foi melhora da quando a CTC foi relacionada com a incubação para el evação do $\mathrm{pH}$ em $\mathrm{CaCl}_{2}$ a 5,9 , o que pode ter ocorrido pela inclusão de maior número de amostras na correlação e/ou pela menor variação nos valores de $\mathrm{pH}$ obtidos pela leitura em solução sal 
Tabela 4. Relação entre a quantidade de carbonato de cálcio necessária para el evar o pH em água e em $\mathrm{CaCl}_{2}$ por incubação à valores 6,5 e 5,9 respectivamente (y) e al gumas propriedades dos solos $(x)$

\begin{tabular}{|c|c|c|}
\hline $\begin{array}{l}\text { Propriedades } \\
\text { dos solos }\end{array}$ & $\begin{array}{l}\text { Quantidades de } \mathrm{CaCO}_{3} \mathrm{p} / \\
\mathrm{pH} \mathrm{H}_{2} \mathrm{O} 6,5(\mathrm{t} / \mathrm{ha})^{l}\end{array}$ & $\begin{array}{l}\text { Quantidades de } \mathrm{CaCO}_{3} \mathrm{p} / \\
\mathrm{pH} \mathrm{CaCl} \\
\mathrm{pH} 5,9(\mathrm{t} / \mathrm{ha})^{2}\end{array}$ \\
\hline $\begin{array}{l}\text { CTC a pH } 7,0 \\
\text { emg/l00g TFSA }\end{array}$ & $\begin{array}{l}y=0,807 x-1,745 \\
r=0,818 * *\end{array}$ & $\begin{array}{l}y=0,798 x-1,87 \\
r=0,884^{* *}\end{array}$ \\
\hline $\begin{array}{l}\mathrm{H}^{\mathrm{O}}+\mathrm{Al}^{3+} \\
\text { emg/l }\end{array}$ & $\begin{array}{l}y=1,158 x-1,563 \\
r=0,930 * *\end{array}$ & $\begin{array}{l}y=1,103 x-1,27 \\
r=0,979 * *\end{array}$ \\
\hline $\begin{array}{l}\text { matéria } \\
\text { orgânica, \% }\end{array}$ & $\begin{array}{l}y=3,214 x+1,748 \\
r=0,727 * *\end{array}$ & $\begin{array}{l}y=2,097 x+1,856 \\
r=0,531 * *\end{array}$ \\
\hline argila, \% & $\begin{array}{l}y=0,146 x+0,431 \\
r=0,740 * *\end{array}$ & $\begin{array}{l}y=0,140 x+0,532 \\
r=0,795^{*} *\end{array}$ \\
\hline
\end{tabular}

I. Dados obtidos com 17 amostras, excetuando portanto as 6 amostras problemas.

2. Dados obtidos com as 23 amostras. 


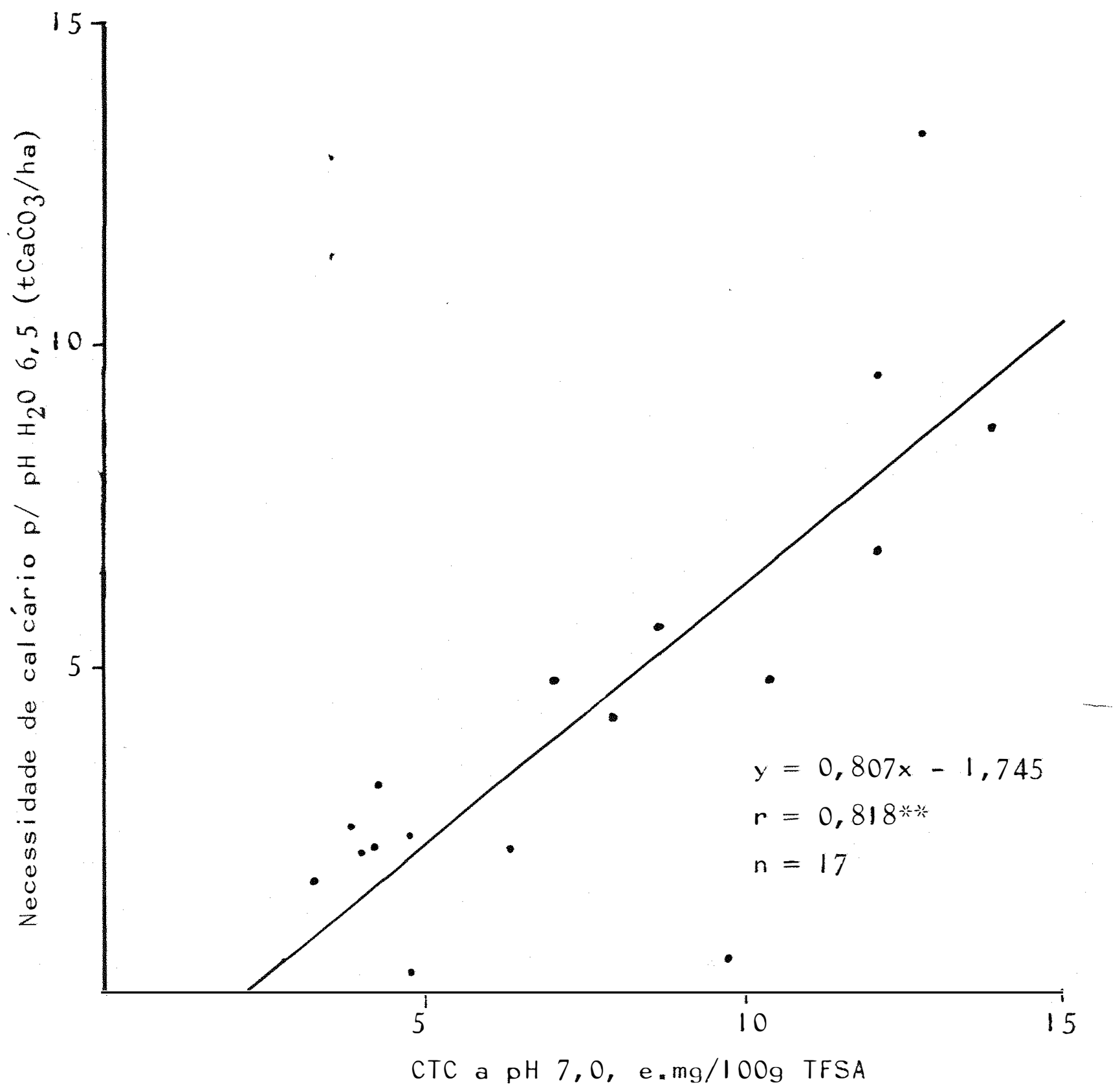

Figura 5 - Relação entre a CTC determinada a pH 7,0 e a N.C. para elevar o pH em $\mathrm{H}_{2} \mathrm{O}$ dos solos a 6,5 (foram excluidas as 6 amostras problemas) 
na, propiciando valores mais reais para a necessidade de calcário dos solos. 0 conjunto de observações efetuadas reforça, portanto, a estreita relação entre a CTC e a necessidade de carbonato de cálcio para elevação do $\mathrm{pH}$ dos solos, como mos trada anteriormente por ROSS et ali i (1964) e DEVILIERS \& JACKSON (1967), e confirmada por KAMINSKI (1974) para solos do Rio Grande do Sul.

0 teor de $\left(\mathrm{H}^{\mathrm{O}}+\mathrm{Al}^{3+}\right)$, determinado por extração com acetato de cál cio IN, mostrou-se altamente correlacionado com a necessidade de calcário obtida por incubação, conforme a tabela 4. Nas figuras 6 e 7 são mostradas as relações obtidas entre as variáveis em questão, ficando evidenciado, novamente, que a relação foi melhorada quando comparou-se esta propriedade do solo com os dados de incubação para pH em $\mathrm{CaCl}_{2}$ (figura 7), cujo coeficiente de correlação é mais eleva do, sendo também menor a dispersão dos pontos em torno da reta encontrada*

O $\left(\mathrm{H}^{\mathrm{O}}+\mathrm{Al}^{3+}\right)$, também denominado de acidez potencial (KINJO, 1983) deve, necessariamente, estar relacionado com as doses de carbonato de cál cio necessárias para neu tralizá-lo, ou para el evar o $\mathrm{pH}$ a um valor determinado. Os dados obtidos no presente trabal ho concordam portanto, com os resultados obtidos por ROSS et al ii, para solos de Michigan (USA) e assemelham-se as observações de KAMINSKI (1974), que obteve estreita correl ação entre os valores da acidez poten cial com a necessidade de calcário para elevar o $\mathrm{pH}$ em $\mathrm{H}_{2} \mathrm{O}$, de solos do Rio Grande do Sul, a valores determinados.

Os teores de argila e de matéria orgânica tam bém revel am uma relação de dependência significativa quando comparados às necessidades de carbonato de cálcio, conforme - 


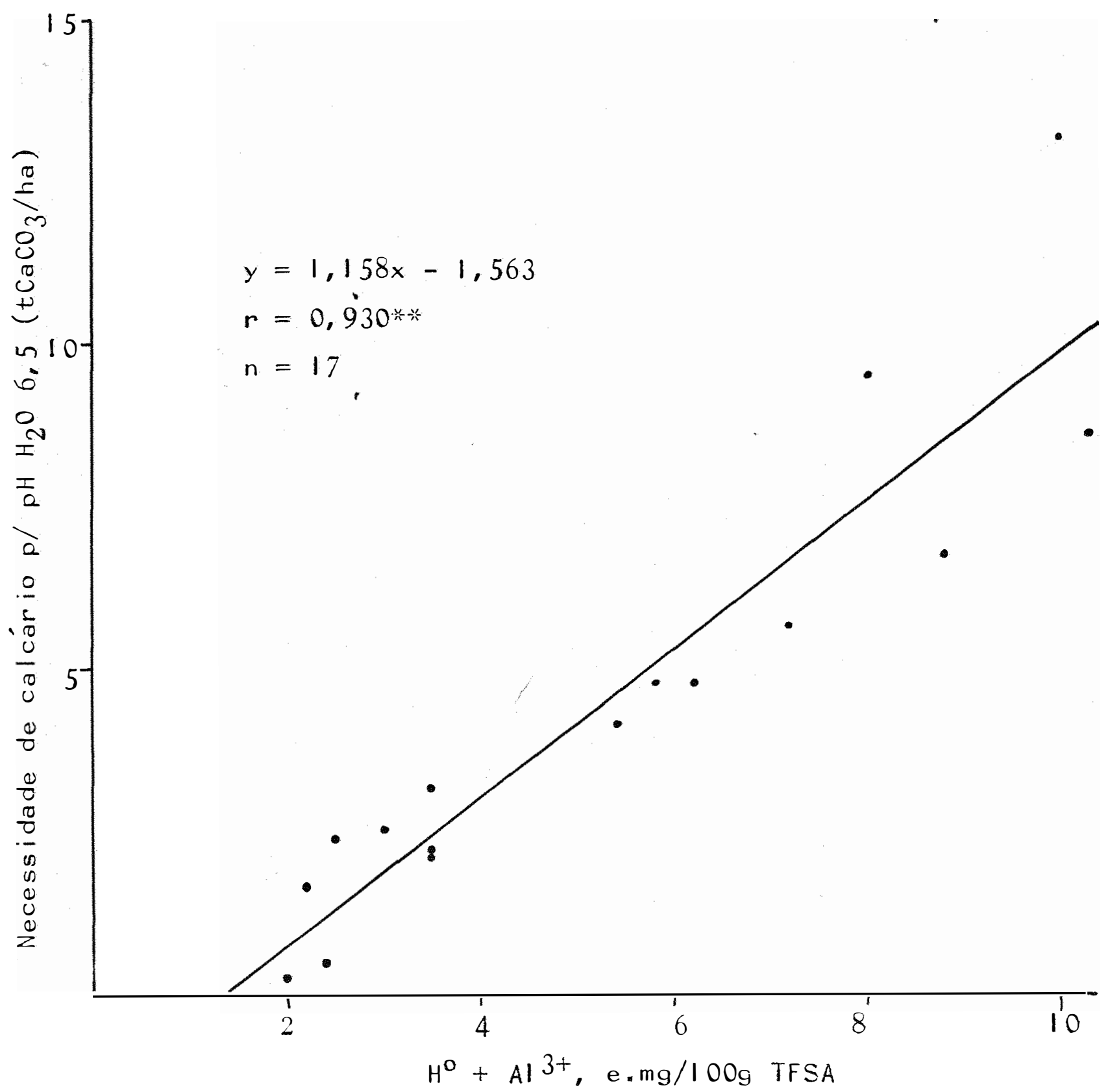

Figura 6 - Relação entre o teor de hidrogênio mais alumínio $\left(\mathrm{H}^{\mathrm{O}}+\mathrm{Al}^{3+}\right)$ e a necessidade de calcário para ele var o pH em $\mathrm{H}_{2} \mathrm{O}$ dos solos a 6,5 (foram excluidas as 6 amostras problemas) 


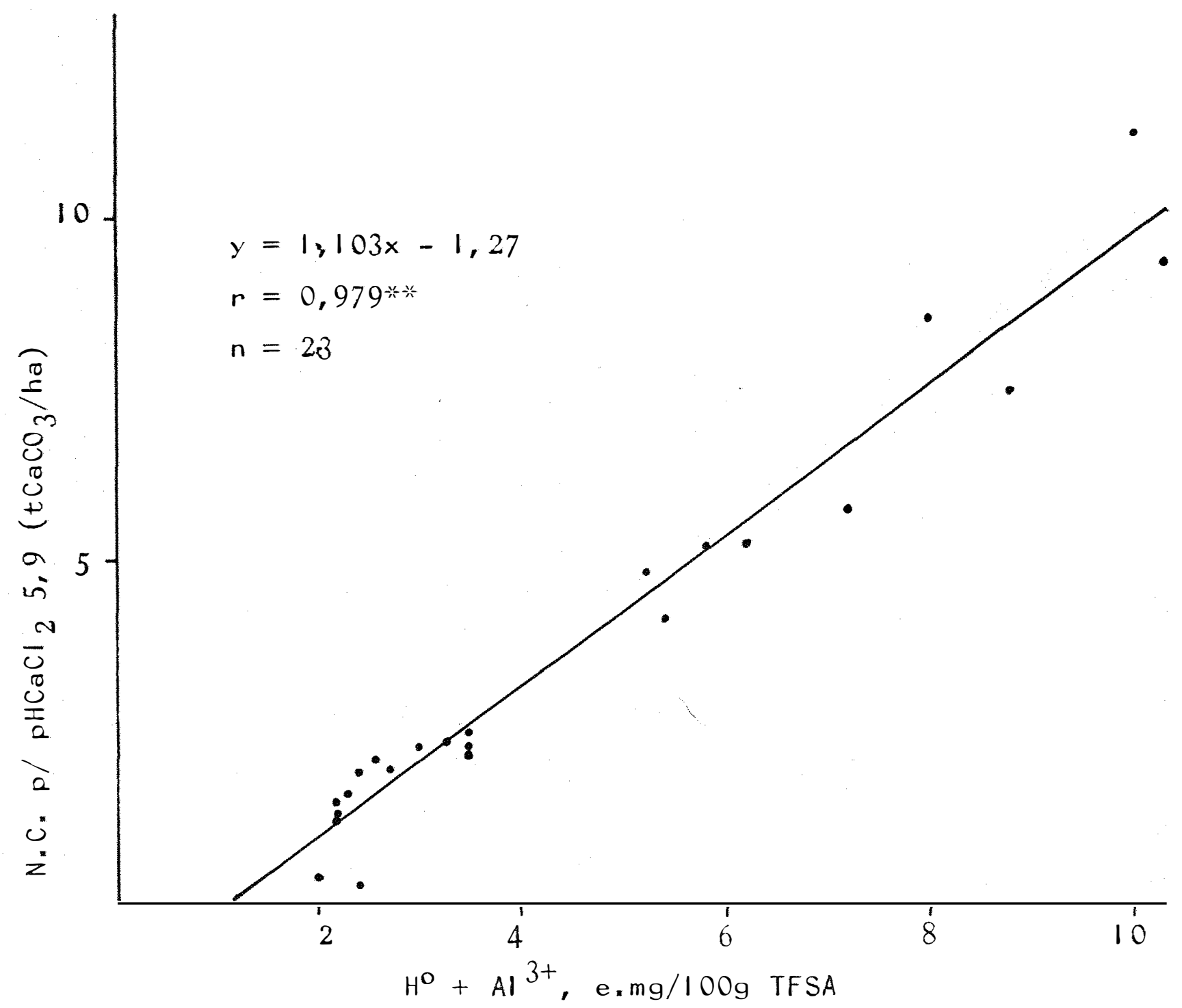

Figura 7 - Relação entre o teor de hidrogênio mais alumínio $\left(\mathrm{H}^{\mathrm{O}}+\mathrm{Al}^{3+}\right)$ e a necessidade de calcário para ele var o $\mathrm{pH} \mathrm{em} \mathrm{CaCl}_{2}$ a 5,9 . 
pode ser observado na tabela 4, concordando com as observa ções de ROSS et alii (1964) para ambas as propriedades dos so los, e com as de KEENEY \& COREY (1963) com relação ao teor de matéria orgânica.

Estas quatro propriedades dos solos mostraram se, portanto, relacionadas com a acidez, sendo os teores de $\left(\mathrm{H}^{\mathrm{O}}+\mathrm{Al}^{3+}\right), \mathrm{CTC}$ a $\mathrm{pH} 7,0$, teor de argila e teor de matéria orgânica, por ordem de importância, as propriedades que mais influenciaram na necessidade de carbonato de cálcio para a elevação do $\mathrm{pH}$, de acordo com os coeficientes de correlação al cançados:

4*6* Relação entre o $\mathrm{pH}$ SMP e o teor de $\left(\mathrm{H}^{\mathrm{O}}+\mathrm{Al}^{3+}\right)$

Comparou-se os valores de $\mathrm{pH}$, obtidos após adição da solução tampão SMP, com os valores de $\left(\mathrm{H}^{\mathrm{O}}+\mathrm{Al}^{3+}\right)$ em e,mg/lo0g de TFSA, obtidos conforme metodologia sugerida por CATANI \& JACINTHO (I 974).

As duas variáveis mostraram-se altamente correlacionadas $\left(r=0,977^{*}\right)$, conforme pode ser observado na figura 8. Estes dados confirmam, portanto, a possibilidade de se determinar os teores de $\left(\mathrm{H}^{\mathrm{O}}+\mathrm{Al}^{3+}\right)$ a partir da leitura direta do $\mathrm{pH}$ da solução tampão SMP após estar em contato com o solo, conforme foi sugerido inicialmente por RAlJ et alii (1979) pa ra solos do estado de São Paulo, e mais tarde ratificada pelas observações de QUAGGIO (1983a) para solos do mesmo estado. Para determinações de rotina, torna-se necessário, entretanto, calibrar o método com uma população de solos bastante ampla: 0 método sugerido, pela sua precisão relativamente alta, apre sentaria como principais vantagens, segundo QUAGGIO (19836), o 


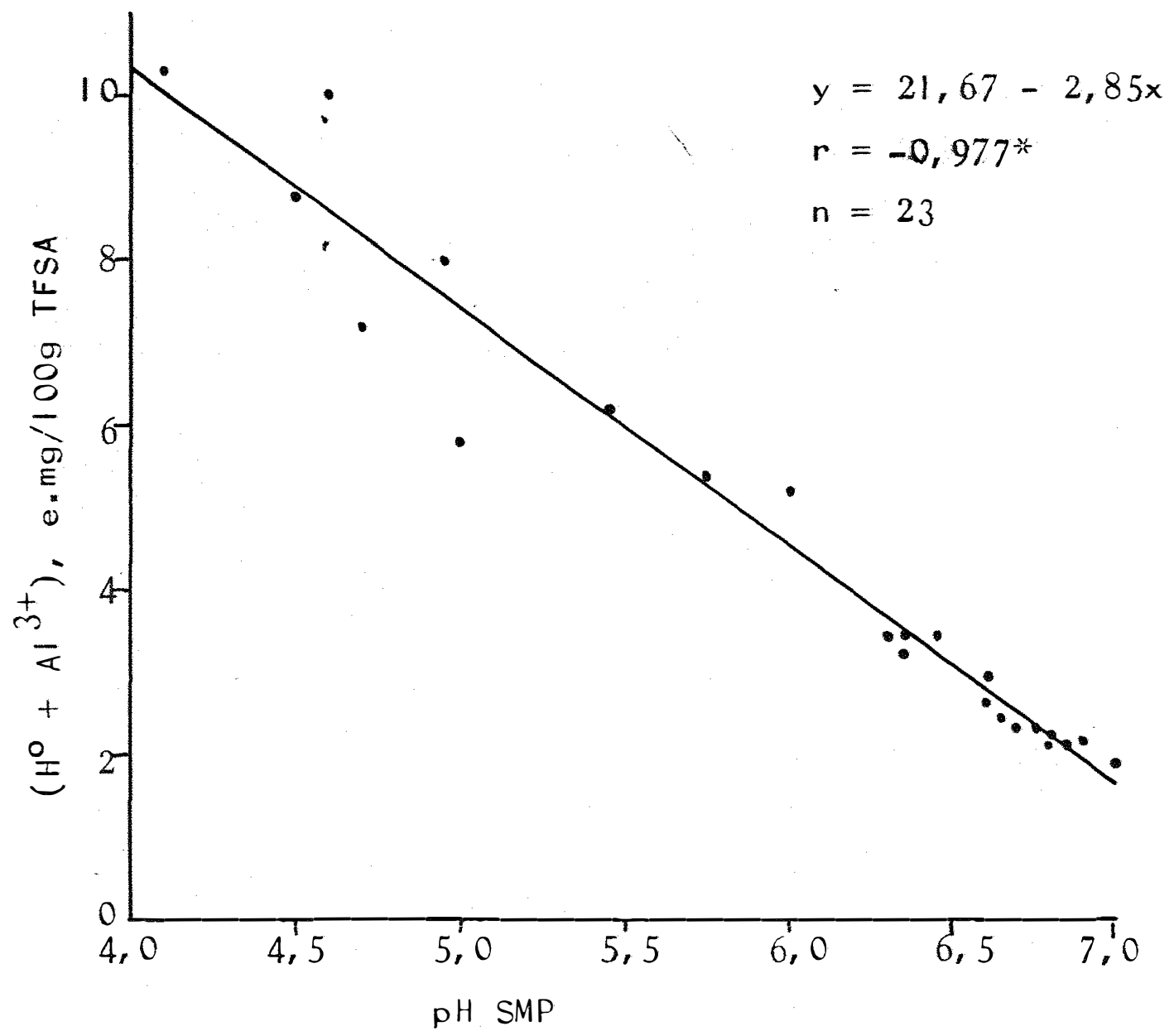

Figura 8 - Relação entre o pH da suspensão solo: água:solução SMP (pHSMP) e os teores de $\mathrm{H}^{\mathrm{O}}+\mathrm{Al}^{3+}$ das amostras não incubadas 
fato de ser bastante simples e rápido, adaptando-se às condiçôes de rotina dos laboratórios que realizam grande número de análises diariamente. Isso el iminaria a necessidade de titulação e o preparo diário da soluçâo de acetato de cálcio, que é ainda muito influenciada pela qualidade do reagente uti I izado:

Apesar dos citados autores terem utilizado rel açôes solo:água:tampão diferentes das usadas neste trabalho, isto parece não afetar significativamente os resultados finais, dada a estreita correlação observada, facilitando ainda os trabalhos de rotina, mesmo nos laboratórios onde se fez a leitura do $\mathrm{pH}$ em $\mathrm{H}_{2} \mathrm{O}$ na relação solo: água de $1: 1$, pois permite nas mesmas amostras a determinação do $\mathrm{pH}$ SMP.

Foram comparadas ainda, com base na equação de regressão mostrada na figura 8 , os valores de $\left(\mathrm{H}^{\mathrm{O}}+\mathrm{Al}^{3+}\right)$ que seriam obtidos pela leitura do $\mathrm{pH}$ SMP das amostras $\left(\mathrm{H}^{\mathrm{O}}+\mathrm{Al}^{3+}\right.$ calculado) com os valores de $\left(H^{\circ}+\mathrm{Al}^{3+}\right)$ obtidos pelo método titulométrico $\left(H^{\circ}+A^{3+}\right.$ determinado), conforme é mostrado na tabela 5. Observa-se uma correlação altamente significativa entre os dois valores comparados $\left(r=0,977^{*}\right)$ sendo praticamente insignificantes as diferenças encontradas, concordando portanto com os resultados obtidos por QUAGGIO (I983a).

Com base nestes resultados, torna-se possivel avaliar, conhecendo-se os valores da soma de bases das diferentes amostras, a capacidade de troca de cátions e a saturação em bases das mesmas. A CTC pode ser avaliada somando-se os valores da soma de bases, aos valores de $\left(\mathrm{H}^{\mathrm{O}}+\mathrm{Al}^{3+}\right)$ obtidos pela leitura do pH SMP (CTC calculada), através da equação de regressão. A saturação em bases calculada pelo método proposto pode ser avaliada segundo a fórmula: 
Tabela 5: pH SMP e os valores de $\left(\mathrm{H}^{\circ}+\mathrm{Al}^{3+}\right)$ calculados pela equação: $\left(\mathrm{H}^{\mathrm{O}}+\mathrm{Al}^{3+}\right)=21,67-2,85 \mathrm{pH}$ SMP, bem como, determinado pela extração com $\mathrm{Ca}(O A C)_{2} I \mathrm{~N}$ a $\mathrm{pH}$ $7,0$.

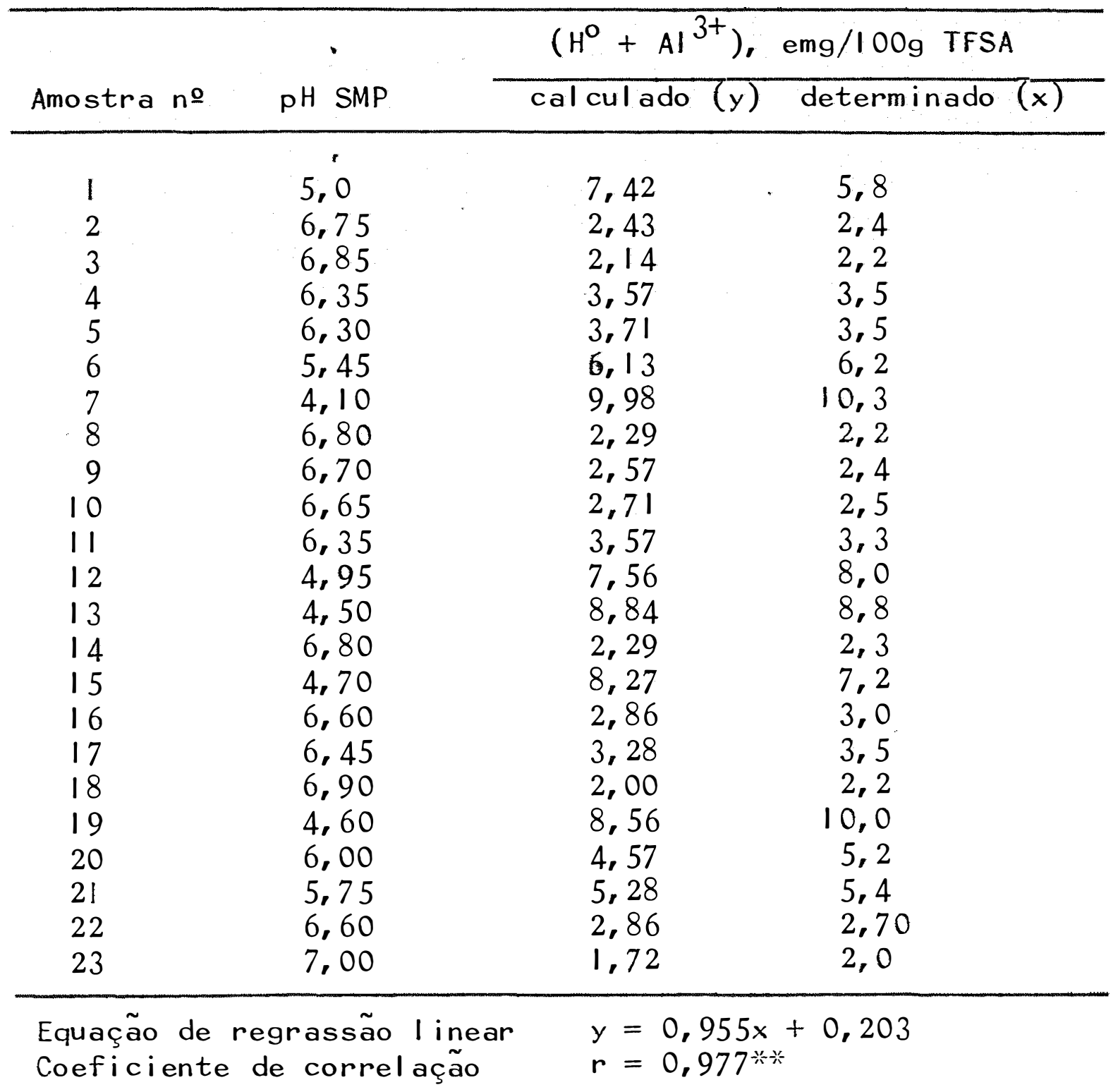




$$
\mathrm{v} \% \text { cal culada }=\frac{S}{\text { CTC calculada }} \times 100
$$

Neste sentido foram efetuadas, para os solos do presente estudo, comparações entre os valores de CTC e vaI or $V$ calculados pelo método proposto, com os valores obtidos pela determinação normal deste parâmetros. Os dados obtidos constam da tabela $\%$, onde verifica-se que tanto para a CTC quanto para os valores de $V$, os dados obtidos são muito similares, ocorrendo ém ambos os casos uma correl ação altamente siginificativa entre as variáveis analizadas.

4.7. Relação entre o pH em $\mathrm{H}_{2} \mathrm{O}$ e em $\mathrm{CaCl}_{2}$ e a saturação de bases do solo

Nas figuras 9a e 9b estão representadas as rel ações obtidas entre os valores de $\mathrm{pH}$ em $\mathrm{H}_{2} \mathrm{O}$ e $\mathrm{pH}$ em $\mathrm{CaCl}_{2}$ com os valores de saturação em bases, determinados para as di ferentes amostras: Apesar dos coeficientes de correlação serem elevados, observa-se que o número de amostras com valor $V$ superior a $60 \%$ é bastante reduzido, propiciando margem de dúvidas a respeito da validade de utilização das equações obtidas, quando se deseja obter os valores de $\mathrm{pH}$ que seriam atingidos pela elevação da saturação em bases a valores superio res ao anteriormente citado. Mesmo assim, resolvendo-se a e quação da figura 9a para um valor da saturação em bases de $85 \%$, observa-se que corresponderia a um $\mathrm{pH}$ em $\mathrm{H}_{2} \mathrm{O}$ igual de 6,3, valor bem inferior portanto ao sugerido pela equação obtida por CATANI \& GALLO (1955) para 85 solos do estado de São Paulo $\left(\mathrm{pH} \mathrm{H}_{2} \mathrm{O}=4,29+0,317 . \mathrm{V} \%\right.$, com $\left.\mathrm{r}=0,947\right)$ e ainda inferior ao resultado obtido por RAlJ et alii (1968), cujas equações obtidas para solos com horizonte B latossólico e textural 
Tabela 6. Relações entre a CTC determinada a pH 7,0 e a CTC cal culada e os valores $\mathrm{V} \%$ determinado e calculado

\begin{tabular}{|c|c|c|c|c|}
\hline $\begin{array}{c}\mathrm{n} 0 \\
\text { Amostra }\end{array}$ & \multicolumn{2}{|c|}{$\begin{array}{cc}\text { CTC } & \text { CTC } \\
\text { determinada }(x) \text { cal cul ada }(y)\end{array}$} & \multicolumn{2}{|c|}{$\underset{\mathrm{V} \%}{\operatorname{determinado}(x) \text { cal culado }(y)}$} \\
\hline 1 & $7,02^{\circ}$ & 8,64 & 17 & 14 \\
\hline 2 & 5,02 & 5,05 & 52 & 52 \\
\hline 3 & 4,52 & 4,36 & 49 & 51 \\
\hline 4 & $4,35^{\circ}$ & 4,42 & 20 & 19 \\
\hline 5 & 4,03 & 4,24 & 13 & 13 \\
\hline 6 & 10,38 & 10,31 & 40 & 40 \\
\hline 7 & 13,91 & 13,59 & 26 & 27 \\
\hline 8 & 5,06 & 5,15 & 56 & 55 \\
\hline 9 & 8,77 & 8,94 & 52 & 71 \\
\hline 10 & 4,83 & 5,04 & 48 & 46 \\
\hline 11 & 6,38 & 6,65 & 48 & 46 \\
\hline 12 & 12,06 & 11,62 & 34 & 35 \\
\hline 13 & 12,09 & 12,13 & 27 & 27 \\
\hline 14 & 3,98 & 3,97 & 42 & 42 \\
\hline 15 & 8,65 & 9,72 & 17 & 15 \\
\hline 16 & 3,86 & 3,72 & 22 & 23 \\
\hline 17 & 4,23 & 4,01 & 17 & 18 \\
\hline 18 & 3,29 & 3,09 & 33 & 35 \\
\hline 19 & 12,8 & 11,36 & 22 & 25 \\
\hline 20 & 9,66 & 9,03 & 44 & 49 \\
\hline 21 & 8,00 & 7,88 & 32 & 33 \\
\hline 22 & 4,25 & 4,41 & 36 & 35 \\
\hline 23 & 4,83 & 4,55 & 58 & 62 \\
\hline $\begin{array}{l}\text { Eq. regr. } 1 \text { in } \\
\text { Coef } x \text { correl }\end{array}$ & \multicolumn{2}{|c|}{$\begin{array}{l}y=0,952 x+0,334 \\
r=0,985^{*} \text { 并 }\end{array}$} & \multicolumn{2}{|c|}{$\begin{array}{l}y=1,01 x-0,078 \\
r=0,992 \% *\end{array}$} \\
\hline
\end{tabular}




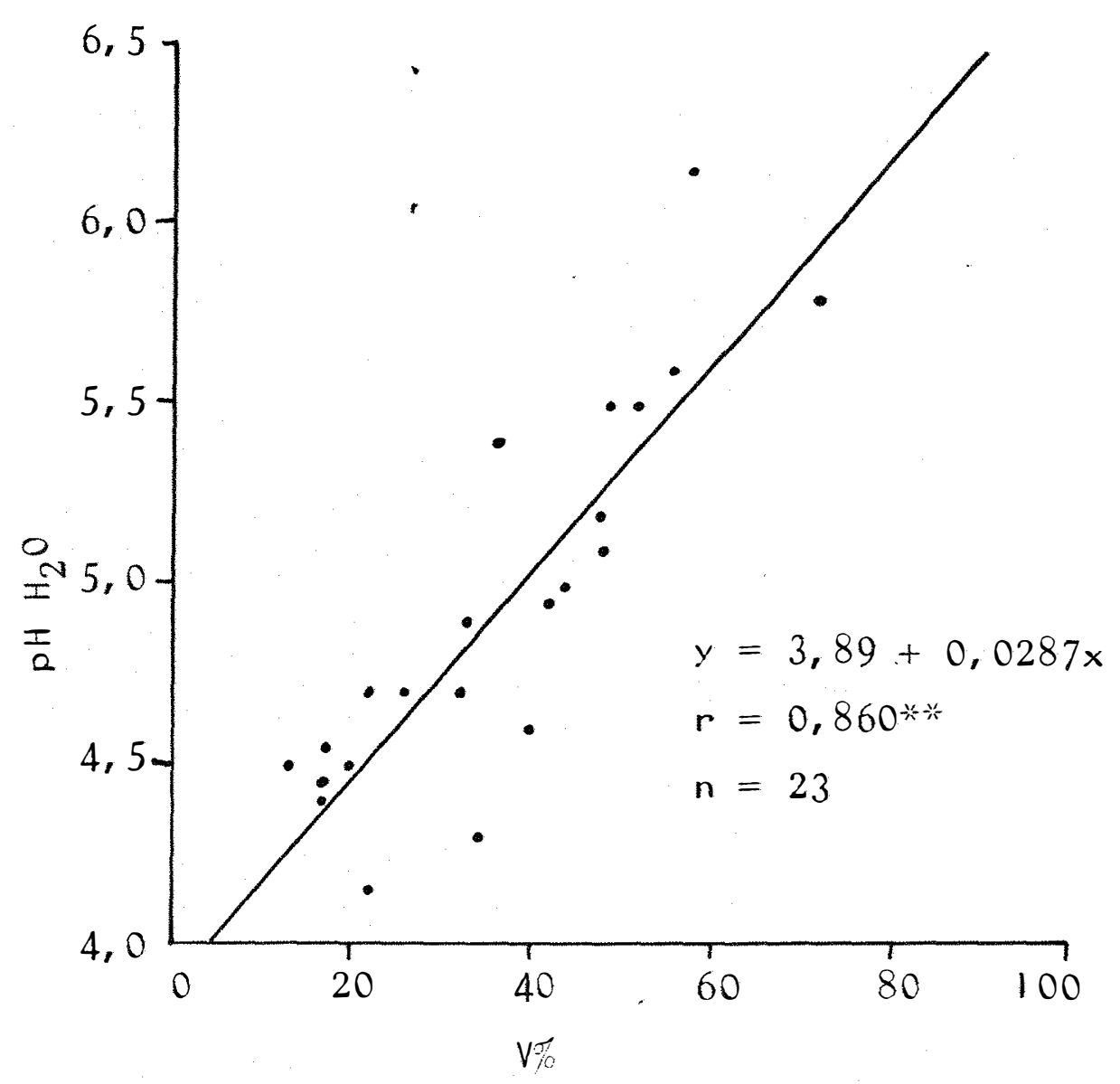

Figura 9a - Rel ação entre a saturação de bases (valor $\mathrm{V} \%$ ) e o pH em $\mathrm{H}_{2} \mathrm{O}$ das amostras não incubadas 


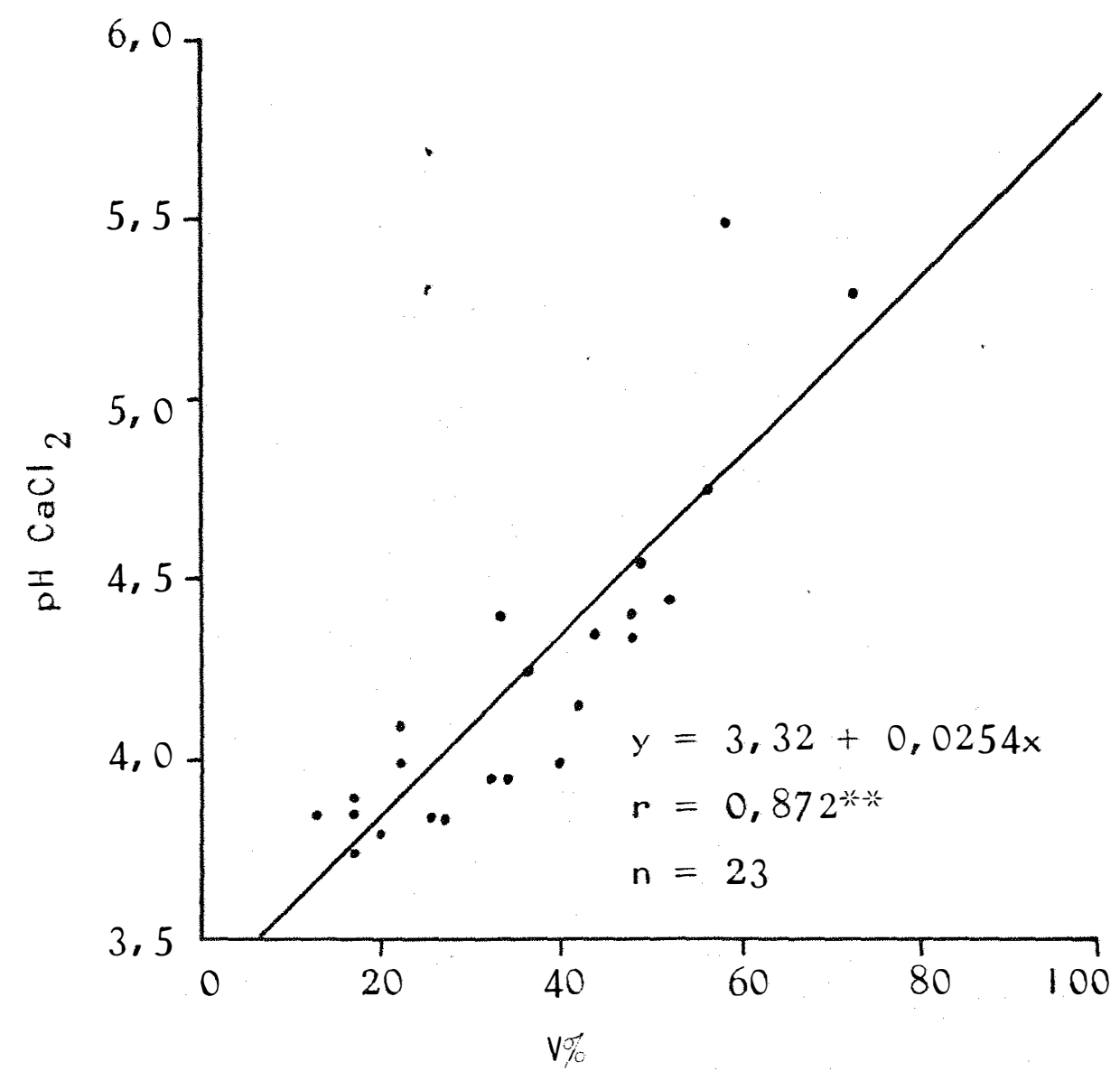

Figura 9b - Relação entre a saturação de bases (valor $\mathrm{V} \%$ ) e o $\mathrm{pH}$ em $\mathrm{CaCl}_{2}$ das amostras não incubadas 
do mesmo estado teriam como resolução para o valor $V$ estipula do um $\mathrm{pH}$ em $\mathrm{H}_{2} \mathrm{O}$ em torno de 6,6. A. equação obtida recentemente por QUAGGIO (1983), para 26 solos do estado de São Paulo $\left(\mathrm{pH} \mathrm{H} \mathrm{H}_{2} \mathrm{O}=4,45+0,021 . \mathrm{V} \%\right.$, com $\left.\mathrm{r}=0,94\right)$, assemelha-se mais, em termos de $\mathrm{pH}$ a ser atingido, à obtida no presente trabalho, embora a deficiêncja de amostragem para valores altos de satu ração de bases tenha sido praticamente a mesma.

A inclusão das leituras de $\mathrm{pH}$ em $\mathrm{CaCl}_{2}$, quando comparadas com os valores de saturação em bases das mesmas amostras (figura 9b), não afetol muito a qualidade da correlação, visto que o coeficiente de correlação foi ligeiramente superior ao obtido no caso anterior, observando-se ainda que a representatividade da equação obtida, fica prejudicada quan do se deseja avaliar, com segurança, o phl em $\mathrm{CaCl}_{2}$ que seria atingido por altos valores de saturação em bases.

No sentido de minimizar tal problema, foram feitas comparações com maior número de amostras, utilizando se para tanto, os dados obtidos nos diversos tratamentos com carbonato de cálcio, até a $\mathfrak{s}^{a}$ dose aplicada, visto que acima desta dose muitas amostras ultrapassaram o pH em $\mathrm{H}_{2} \mathrm{O} 7, \mathrm{O}$. Não são incluidas, nestas comparações, as 6 amostras problemas* Os resultados obtidos são mostrados nas figu ras l Oa e lOb. Resolvendo-se as equações de regressão I inear encontradas nestas comparações para alguns valores de saturação em bases, observa-se que, respectivamente para valores de $75 \%, 63 \%$ e $51 \%$ do valor $\mathrm{V} \%$, corresponderiam, para as amostras estudadas valores de $\mathrm{pH}$ em $\mathrm{H}_{2} \mathrm{O}$ de $6,5,6,0$ e 5,5 e valores de $\mathrm{pH}$ em $\mathrm{CaCl}_{2}$ de 5,9, 5,4 e 4,9. A extrapol ação destes valores em termos de saturação de bases a ser atingida em recomencía ções de calagem de rotina, objetivando a elevação do $\mathrm{pH}$ a va- 


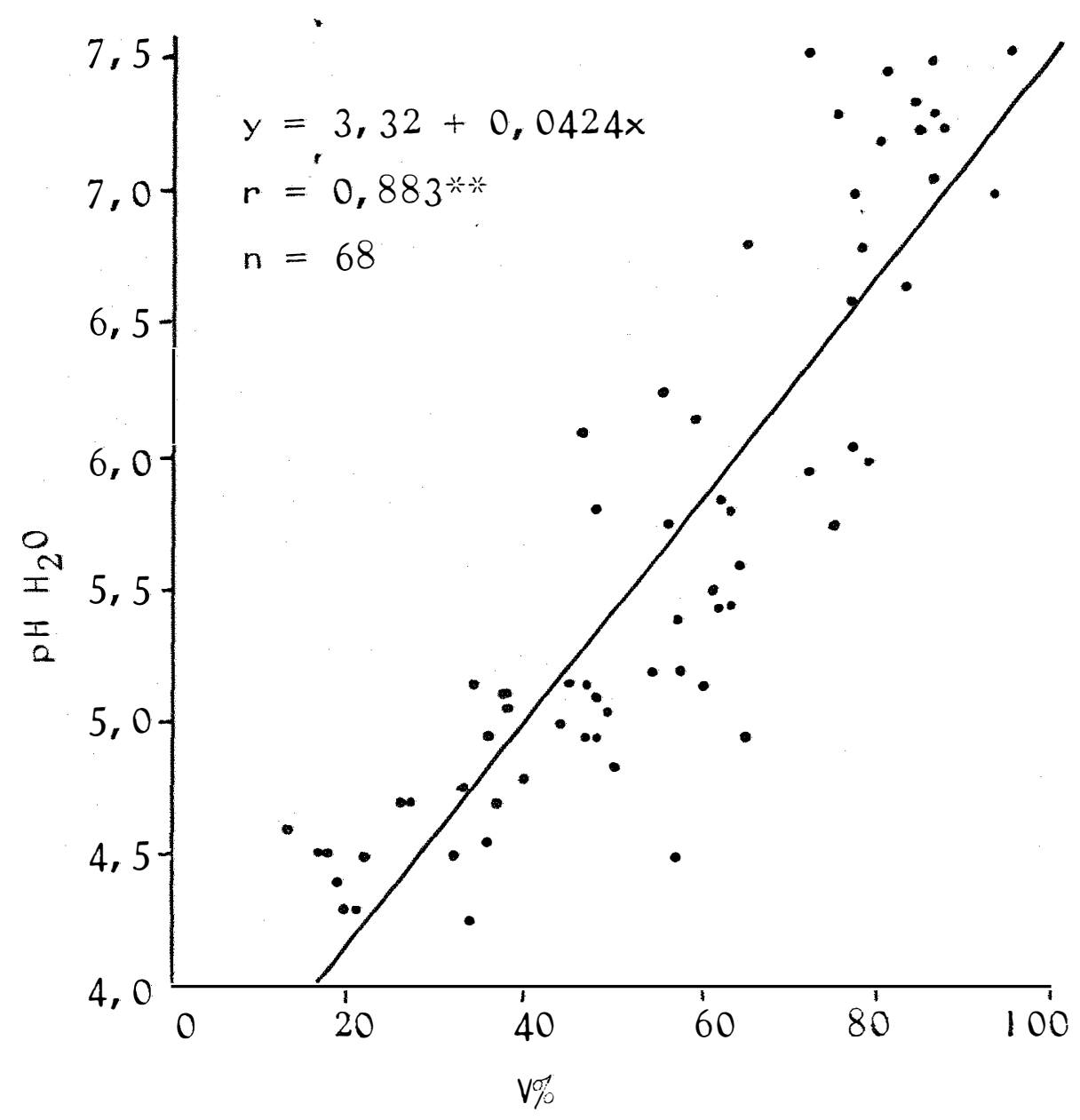

Figura l0a - Relação entre a saturação de bases (valor $\mathrm{V} \%$ ) e o $\mathrm{pH}$ em $\mathrm{H}_{2} \mathrm{O}$ das amostras nos trata mentos efetuados 


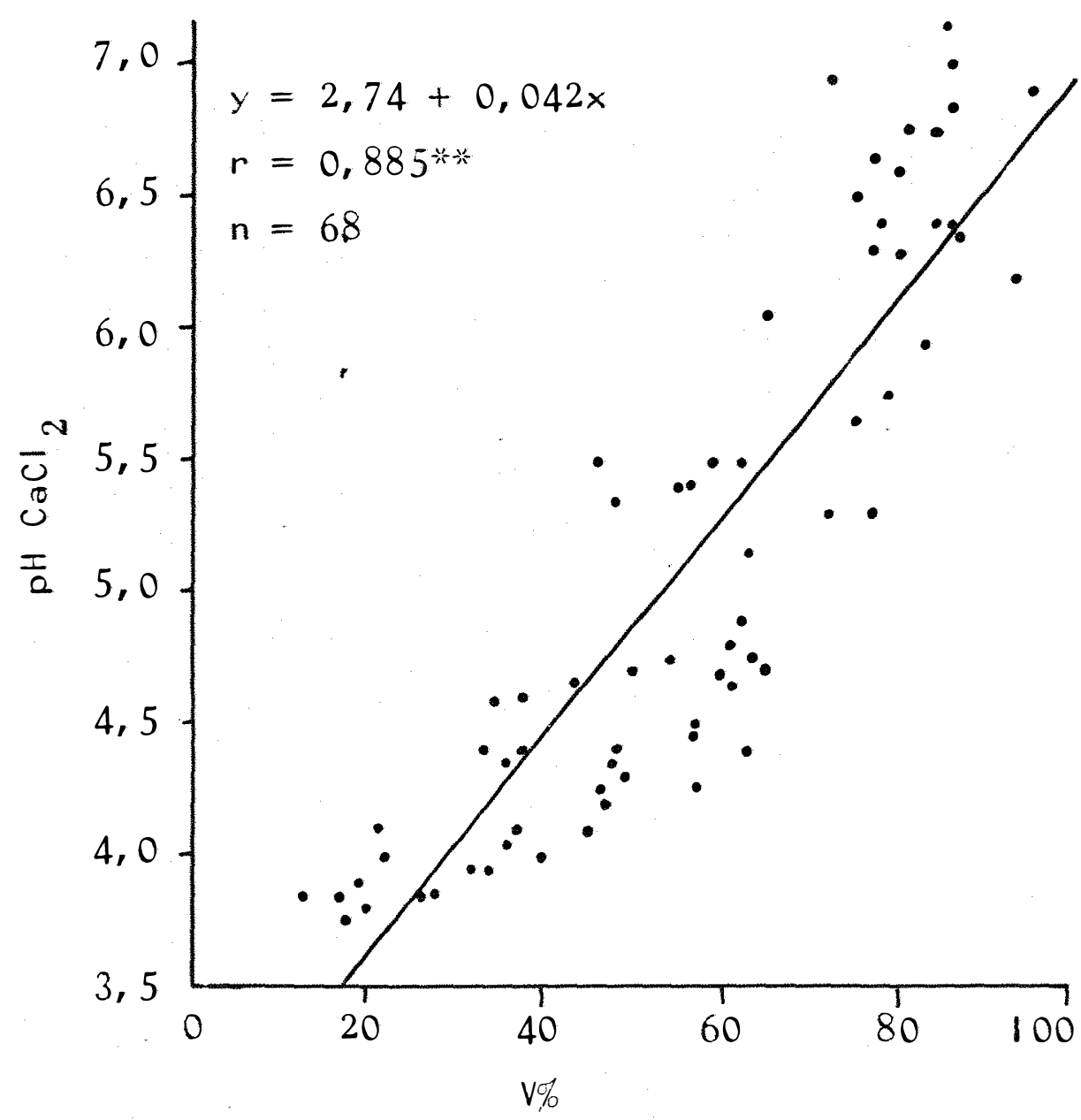

Figura lob - Rel ação entre a saturação de bases (valor V\%) e o pH em $\mathrm{CaCl}_{2}$ das amostras nos trata mentos efetuados 
lores determinados merece restrições, entretanto, por duas ra zões principais. A primeira delas é a de que a boa parte dos solos utilizados para se chegar às equações, constantes das figuras $10 \mathrm{a}$ e $10 \mathrm{~b}$, constituem-se de amostras do horizonte sub superficial; e a segunda é porque o valor $\mathrm{V} \%$ indicado pela equação para elevar,o $\mathrm{pH} \mathrm{H}_{2} \mathrm{O}$ a $6,5(75 \%)$ é inferior ao encon trado por outros pesquizadores que trabalharam com solos do mesmo estado (RAlJ, et alii, 1968; CAMARGO \& RAlJ, 1975), que indicam um valor aproximado de $85 \%$ para se atingir o mesmo va lor de pH. CATANI \& ALONSO (1969) quando testaram, dentre vários outros métodos, o método da saturação em bases sugerido por CATANI \& GALLO (1955), também verificaram que a el evação do valor $\mathrm{V}$ a $85 \%$, corresponderia com mais segurança ao valor de $\mathrm{pH}$ em $\mathrm{H}_{2} \mathrm{O}$ anteriormente indicado. Neste sentido optou-se, quando foi testado o método da saturação de bases, por elevar a saturação de bases a $85 \%, 70 \%$ e 50\%, respectivamente para se atingir um $\mathrm{pH}$ em $\mathrm{H}_{2} \mathrm{O} 6,5,6,0$ e 5,5, ou um $\mathrm{pH}^{\prime}$ em $\mathrm{CaCl}_{2}$ de $5,9,5,4$ e 4,9, conforme é mostrado no item 4.9.

4.8. Calibração do método SMP para os solos estudados

As leituras do $\mathrm{pH}$ lido após adição da solução SMP nas amostras rão incubadas foram comparadas por equação de regressão linear, com as necessidades de carbonato de cálcio obtidas por incubação para elevar o pH em $\mathrm{H}_{2} \mathrm{O}$ aos valores $6,5,6,0$ e 5,5 e o pH em $\mathrm{CaCl}_{2}$ a 5,9, 5,4 e 4,9. Os dados constam da tabela 7 , sendo que as figuras correspondentes são encontradas no apêndice (figuras $1,2,3,4,5,6$ ). $0 b-$ serva-se que as equações obtidas são muito similares para as ciuas modalidades de incubação dos solos, o que indica que as 
Tabela 7. Equações de regressão linear e coeficientes de correl ação entre as quantidades de carbonato de cálcio ( $t / h a)$ para elevação do $\mathrm{pH}$ em $\mathrm{H}_{2} \mathrm{O}$ à $6,5,6,0$ e 5,5 e $\mathrm{pH}$ em $\mathrm{CaCl}_{2}$ à 5,9, 5,4 e 4,9 por incubação $(y)$ e o pH da suspensão solo: solução $\operatorname{SM} P(x)$

\begin{tabular}{|c|c|c|}
\hline $\begin{array}{l}\text { Nível de } \mathrm{pH} \\
\text { desejado }\end{array}$ & $\begin{array}{l}\text { Equação de regressão } \\
\text { l i near }\end{array}$ & $\begin{array}{l}\text { Coeficiente de } \\
\text { correlação }(r)\end{array}$ \\
\hline $\mathrm{pH} ! \mathrm{H}_{2} \mathrm{O} \quad 6,5$ & $N C(t / h a)=22,57-3,14$ pHSMP & $-0,862 \%$ \\
\hline $\mathrm{pH} \mathrm{H} \mathrm{H}_{2} \mathrm{O}, 0$ & $N C(t / h a)=18,68-2,608$ phiSMP & $-0,841 *$ \\
\hline $\mathrm{pH} \quad \mathrm{H}_{2} \mathrm{O} \quad 5,5$ & $N C(t / h a)=14,87-2,11$ pHSMP & $-0,852 * *$ \\
\hline $\mathrm{pHCaCl}_{2} 5,9$ & $N C(t / h a)=22,24-3,08 p H S M P$ & $-0,937$ 长 \\
\hline $\mathrm{pH} \mathrm{CaCl} 25,4$ & $N C(t / h a)=18,69-2,63$ pHSMP & $-0,958 * *$ \\
\hline $\mathrm{pH} \mathrm{CaCl}_{2} 4,9$ & $N C(t / h a)=14,8-2,11$ pHSMP & $-0,977 \%$ \\
\hline
\end{tabular}


quantidades de calcário recomendadas pelo método são praticamente iguais (vide também tabelas 7 e 9 adiante). Entretanto, os coeficientes de correlação obtidos entre o pH SMP e a ne -

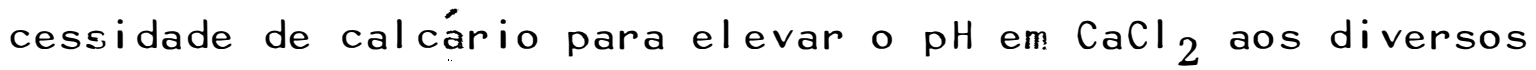
valores são mais elevados, indicando maior segurança em atingir um valor de $\mathrm{pH}$ em solução salina do que em água, quando se apl icam as doses recomendadas.

4.9: Quantidades de carbonato de cálcio indicadas pelos métodos testados

Nas tabelas 8 e 9 estão indicadas as recomendações de calagem, em toneladas de $\mathrm{CaCO}_{3}$ por hectare, pelos quatro métodos testados, e as doses indicadas pelo método da incubação *

Os dados contidos na tabela 8 foram obtidos de 17 amostras, excluidas portanto, as seis amostras problema. $\mathrm{Na}$ tabela 9 , as recomendações são feitas para todas as amostras estudadas. As quantidades de carbonato de cálcio indicadas pelo método SMP foram obtidas, no primeiro caso, das equa ções de regressão encontradas pela calibração do método com o método da incubação, para três valores de $\mathrm{pH}$ em $\mathrm{H}_{2} \mathrm{O}$. No segundo caso, das equações obtidas da calibração com o método da incubação, para três valores de $\mathrm{pH}$ em $\mathrm{CaCl}_{2}$ (equações contidas na tabela 7 ).

As recomendações pelo método da saturação de bases foram feitas, nas dias tabelas, utilizando-se a seguinte fórmula:

$$
\begin{aligned}
& N C=\frac{\text { CTC calculada } \times\left(V_{2}-V_{1} \text { cal culada }\right)}{100}, \text { onde: } \\
& N C=\text { necessidade de calcário, com PRNT } 100 \% \text { em } t / \text { ha: }
\end{aligned}
$$




\begin{tabular}{|c|c|c|c|c|}
\hline $\begin{array}{l}\vdots \\
\vdots \\
\vdots\end{array}$ & $\stackrel{0}{\stackrel{O}{I}}$ & $\begin{array}{l}\overline{0} \\
2 \\
0 \\
0 \\
0 \\
\bar{\nu} \\
\bar{\alpha} \\
\overline{1}\end{array}$ & n? & 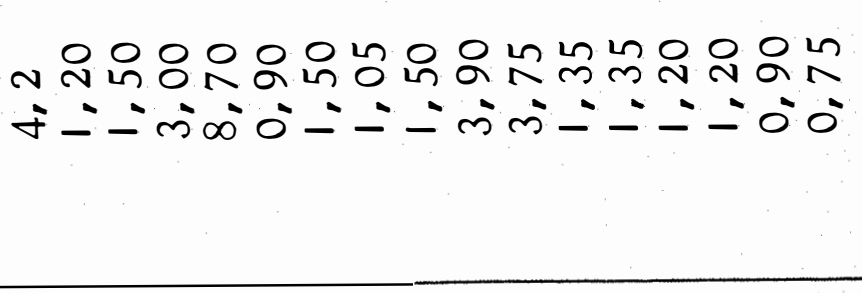 \\
\hline $\begin{array}{l}0 \\
+ \\
0 \\
0 \\
0 \\
0\end{array}$ & $\begin{array}{l}\bar{E} \\
\overline{0} \\
\frac{1}{2} \\
0 \\
0\end{array}$ & $\begin{array}{l}0 \\
+ \\
0 \\
+ \\
0 \\
0 \\
0\end{array}$ & ? & 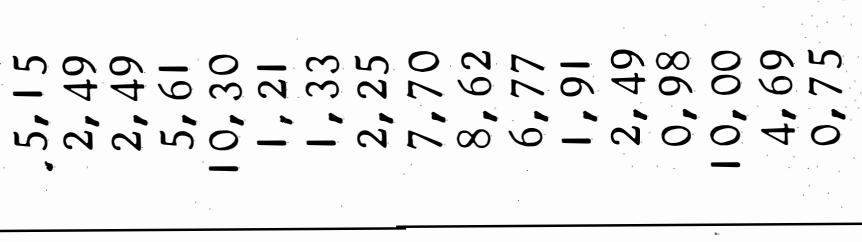 \\
\hline o & $\begin{array}{cc}0 \\
2 \\
0 \\
0 \\
0 \\
0 \\
0 \\
0 & 0 \\
- & 0\end{array} \mid$ & $\begin{array}{l}0 \\
0 \\
0 \\
0 \\
0 \\
0\end{array}$ & 6) & 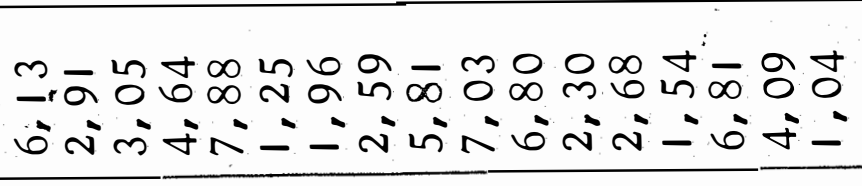 \\
\hline $\begin{array}{l}0 \\
0 \\
0\end{array}$ & $\begin{array}{ll}0 & 0 \\
0 & 0 \\
\frac{0}{0} & + \\
0 & 0 \\
0 & 0\end{array}$ & $\begin{array}{r}0 \\
0 \\
2 \\
20 \\
0 \\
0\end{array}$ & 0 & 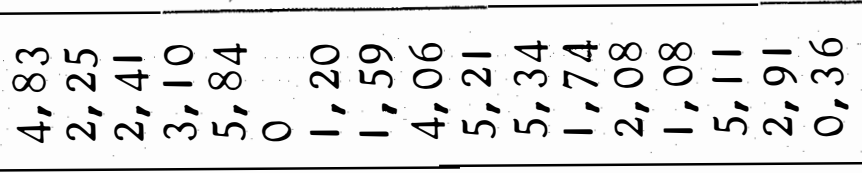 \\
\hline & $\begin{array}{ll}\frac{\pi}{0} & 0 \\
0 & 0 \\
0 & 0 \\
0 & 0 \\
0 & 0\end{array}$ & 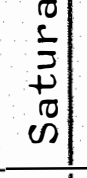 & in & 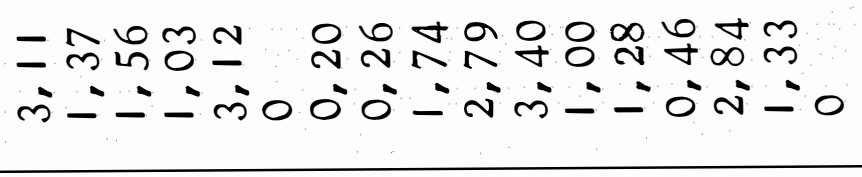 \\
\hline$\frac{0}{0}=$ & 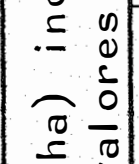 & & 6 & 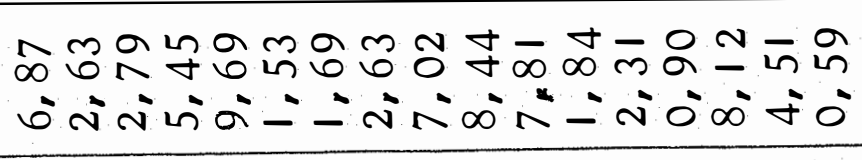 \\
\hline 0 & $\begin{array}{ll}2 & > \\
0 & 0 \\
0 & 0 \\
0 & 0 \\
0 & 1\end{array}$ & $\sum_{i=1}^{0}$ & 0 & 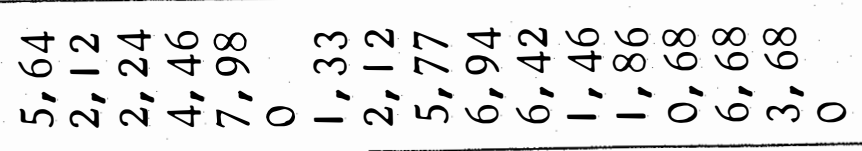 \\
\hline $\begin{array}{ll}0 & 0 \\
2 & 0 \\
0 & 0 \\
0 & 0 \\
1 & 0 \\
1 & 0\end{array}$ & $\begin{array}{ll} \pm & 0 \\
E & : \\
\\
\sigma\end{array}$ & & n) & 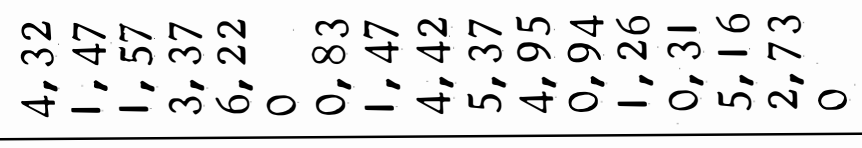 \\
\hline $\begin{array}{l}0 \\
0<0 \\
0 \\
0\end{array}$ & $\overline{0}$ & $2 \%$ & n) & 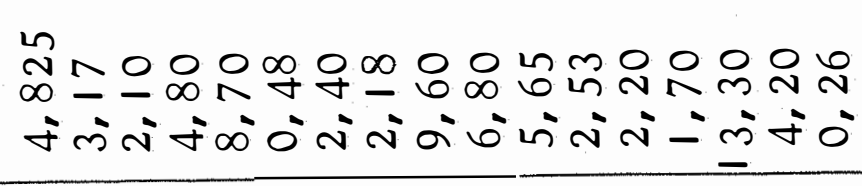 \\
\hline 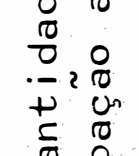 & $\frac{0}{0}$ & 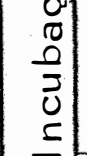 & 0 & 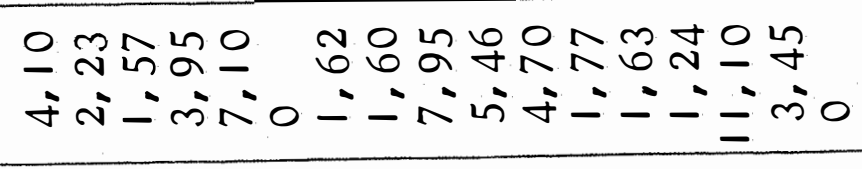 \\
\hline छे ป & $\begin{array}{l}0 \\
0 \\
0 \\
0 \\
2\end{array}$ & & nी & 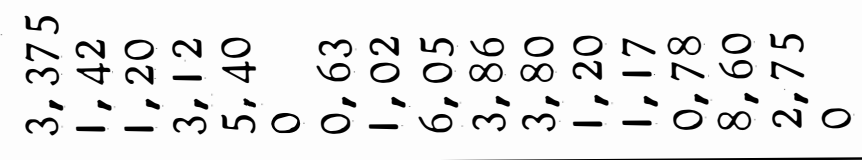 \\
\hline ב & 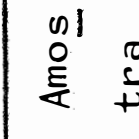 & & & $-\nabla \ln 6 \times a \underline{0}$ \\
\hline
\end{tabular}




\begin{tabular}{|c|c|c|c|c|}
\hline $\begin{array}{l}=1 \\
=1 \\
5 \\
0 \\
0 \\
0 \\
\text { ñ } \\
0\end{array}$ & $\frac{\sigma_{0}^{N}}{0}$ & $\begin{array}{c}\overline{0} \\
2 \\
10 \\
0 \\
0 \\
1 \\
1 \\
= \\
z\end{array}$ & $\begin{array}{l}a \\
f\end{array}$ & 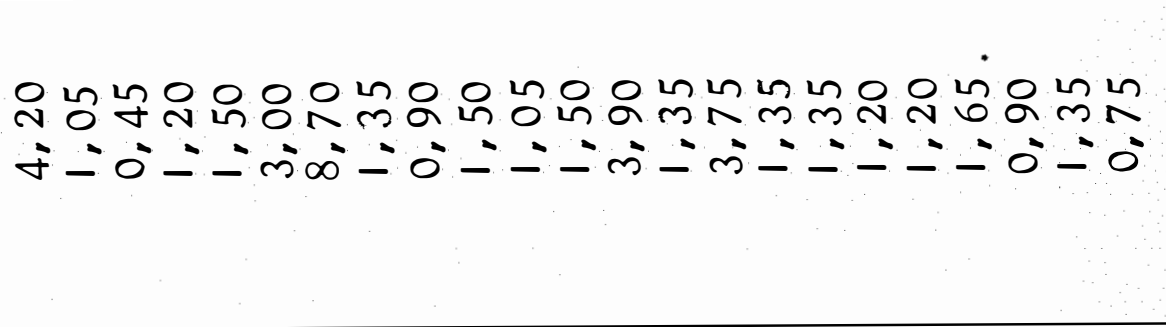 \\
\hline 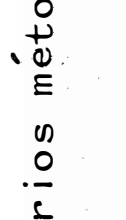 & $\begin{array}{l}\frac{E}{0} \\
\frac{1}{2} \\
0 \\
0\end{array}$ & 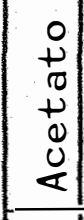 & a) & 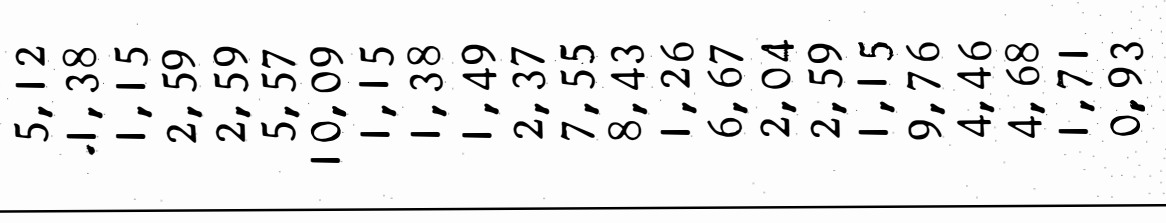 \\
\hline 0 & 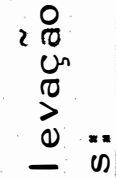 & $\begin{array}{l}\infty \\
0 \\
0 \\
0 \\
0 \\
0\end{array}$ & in & 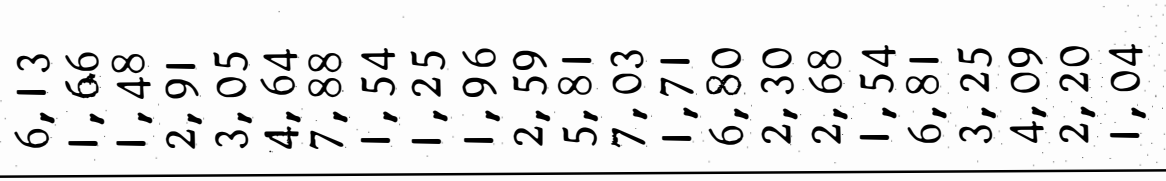 \\
\hline $\begin{array}{l}n \\
0 \\
0 \\
0\end{array}$ & $\begin{array}{ll}0 & 0 \\
0 & 0 \\
0 & 0 \\
\pi & 0 \\
0 & 0 \\
0 & 0\end{array}$ & $\begin{array}{l}\frac{0}{0} \\
0 \\
2 \\
0 \\
0\end{array}$ & $\begin{array}{l}+ \\
n^{\prime}\end{array}$ & 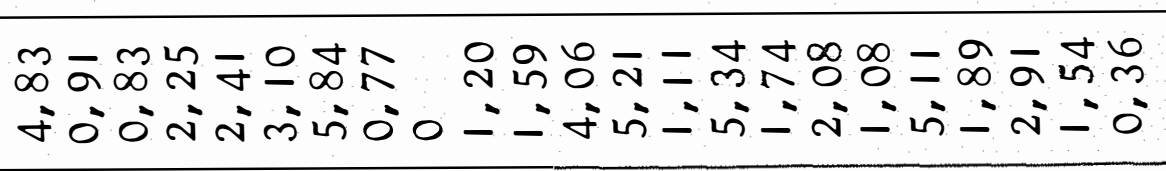 \\
\hline$\frac{0}{0} \underset{0}{0} \overbrace{0}^{0}$ & $\begin{array}{ll}\frac{\pi}{0} & 0 \\
0 & 0 \\
0 & 0 \\
0 & 0 \\
0 & 0\end{array}$ & 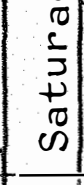 & 9 & 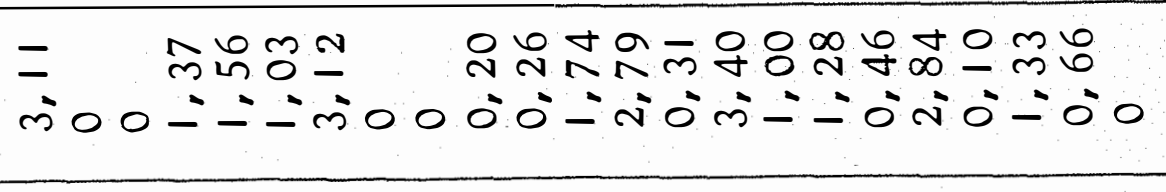 \\
\hline$\frac{\bar{u}}{\bar{r}} \frac{\mathrm{E}}{\mathrm{U}}$ & $\begin{array}{l}\simeq 0 \\
\simeq \frac{1}{0} \\
\simeq \frac{1}{\pi}\end{array}$ & & a & 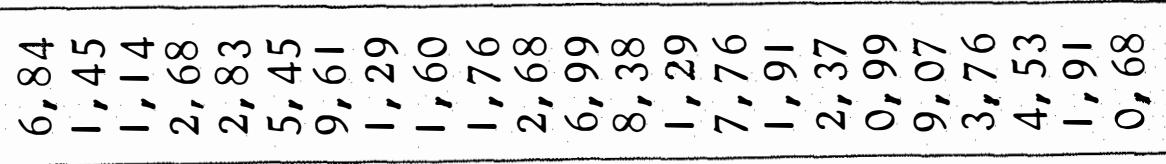 \\
\hline $\begin{array}{ll}0 & 0 \\
0 & 0 \\
0 & 0 \\
0 & 0 \\
0 & 0\end{array}$ & $\begin{array}{ll}0^{2} & n \\
0 & 0 \\
0 & n\end{array}$ & $\sum_{\infty}^{\infty}$ & + & 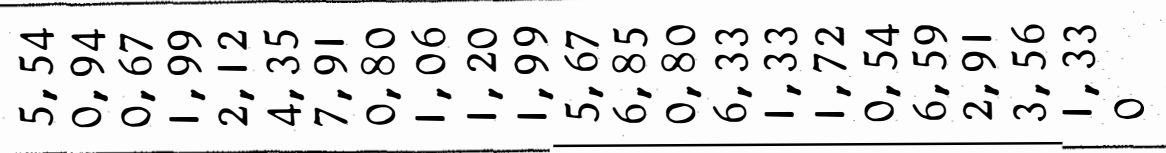 \\
\hline$\frac{1}{0} \frac{1}{0}$ & $\underbrace{ \pm}_{\substack{ \pm 0}} \sum_{0}^{0}$ & & 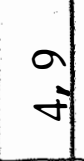 & 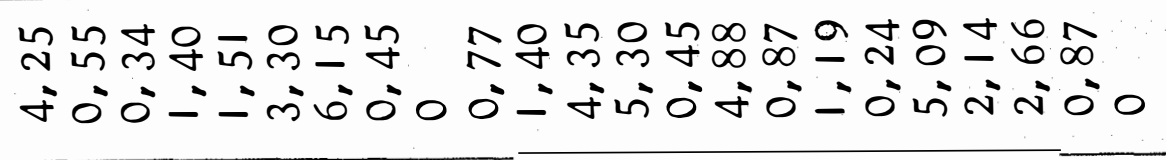 \\
\hline 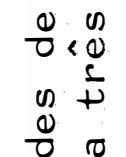 & $\frac{10}{0}$ & 28 & a) & 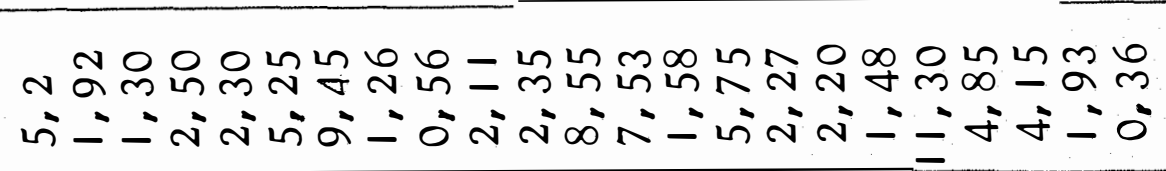 \\
\hline $\begin{array}{ll}\frac{\pi}{0} & 0 \\
0 & 0 \\
-2 & 0 \\
+1 & u \\
\frac{1}{0} & 0 \\
0\end{array}$ & $\begin{array}{l}\frac{0}{0} \\
\frac{\pi}{0} \\
.\end{array}$ & 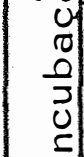 & + & 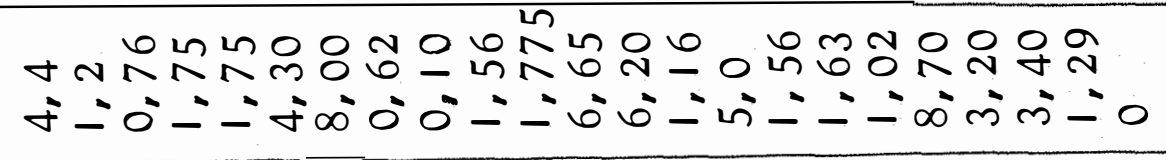 \\
\hline $\begin{array}{ll}3 & 3 \\
0 & 0 \\
a & \end{array}$ & $\begin{array}{l}0 \\
0 \\
0 \\
0 \\
0 \\
Z\end{array}$ & - & a) & 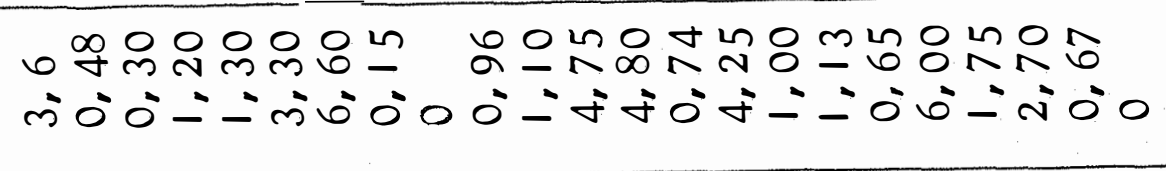 \\
\hline $\begin{array}{l}\overline{0} \\
0 \\
0\end{array}$ & 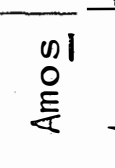 & & & 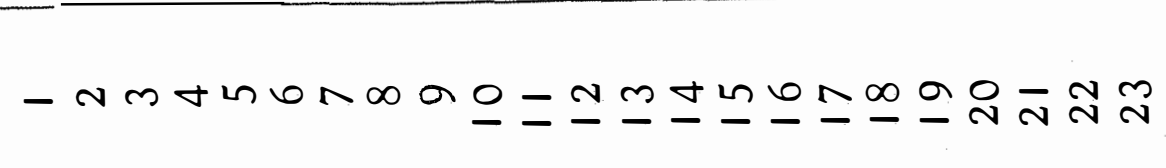 \\
\hline
\end{tabular}


CTC calculada = capacidade de troca de cátions calcula da, obtida pela soma das bases trocá veis (S), acrescida dos valores de $\left(\mathrm{H}^{\circ}+\mathrm{Al}^{+3}\right)$ obtidos por leitura dos va lores de pH SMP, usando-se a fórmula: $\mathrm{H}^{\circ}+\mathrm{Al}^{+3}(\mathrm{e}: \mathrm{mg} / \mathrm{l00g})=21,67-2,85 \times$ pH SMP ( figura 8 )

$\mathrm{v}_{2}=\%$ de saturação de bases a ser atingida

$v_{1}$ calculada $=\%$ de saturação de bases atual das amostras, obtida segundo a fórmula:

$$
v_{1} \text { calculada }=\frac{S}{\text { CTC calculada }} \times 100
$$

Os valores estipulados para o parâmetro $v_{2}$ foram de $85 \%$, 70\% e 50\%, respectivamente para se elevar o pH dos solos em $\mathrm{H}_{2} \mathrm{O}$ a 6,5, 6,0 e 5,5 (tabela 8) e o pH dos solos em $\mathrm{CaCl}_{2}$ a 5,9, 5,4 e 4,9 (tabel a 9).

As recomendações pelo métocio do acetato de cál cio foram feitas somente para el evação do $\mathrm{pH}$ em $\mathrm{H}_{2} \mathrm{O}$ a 6,5 e $\mathrm{pH}$ em $\mathrm{CaCl}_{2}$ 5,9, sendo as doses obtidas, respectivamente, das equações de regressão encontradas nas figuras 6 e 7 . 0 método, portanto, foi ajustado com o método da incubação.

Os coeficientes de correlação obtidos pela com paração das doses indicadas pelos quatro métodos testados com a dose indicada pelo método da incubação, encontram-se nas tạ belas 10 e 11 .

0 método do acetato de cálcio parece ter superado todos os demais em eficiência para controle do $\mathrm{pH}$, tanto em água como em $\mathrm{CaCl}_{2}$, tendo em vista os mais altos coeficien tes de correl ação encontrados. Houve a necessidade, entretanto, do método ser ajustado com o método da incubação, caso contrário haveria uma tendência do método em subestimar as do 
Tabela 10. Coeficientes de correlação entre as quantidades de $\mathrm{CaCO}_{3}$ obtidas por. incubação dos solos à três valores de $\mathrm{pH}$ em $\mathrm{H}_{2} \mathrm{O}$ e as quantidades indicadas pelos métodos testados:

\begin{tabular}{|c|c|}
\hline Méto do & Coeficientes de correl ação $(r)$ \\
\hline & $\mathrm{pH} \mathrm{H}_{2} \mathrm{O} 5,5$ \\
\hline \multirow{4}{*}{$\begin{array}{l}\text { SMP } \\
\text { Saturação de bases } \\
\text { Al trocável }\end{array}$} & $r=0,879 \%$ \\
\hline & $r=0,758 \%$ \\
\hline & $\mathrm{r}=0,422 \mathrm{NS}$ \\
\hline & $\mathrm{pH} \mathrm{H} \mathrm{H}_{2} \mathrm{O}, 0$ \\
\hline \multirow{3}{*}{$\begin{array}{l}\text { SMP } \\
\text { Saturação de bases }\end{array}$} & $r=0,874 * *$ \\
\hline & $r=0,841 * *$ \\
\hline & $\mathrm{pH} \mathrm{H} \mathrm{H}_{2} \mathrm{O} \quad 6,5$ \\
\hline \multirow{3}{*}{$\begin{array}{l}\text { SMP } \\
\text { Saturação de bases } \\
\text { Acetato de cálcio }\end{array}$} & $r=0,862 \%$ \\
\hline & $r=0,855^{* *}$ \\
\hline & $r=0,931$ 并 \\
\hline
\end{tabular}


Tabela 11. Coeficientes de correlação entre as quantidades de $\mathrm{CaCO}_{3}$ obtidas por incubação dos solos a três valores de $\mathrm{pH}$ em $\mathrm{CaCl}_{2}$ e as quantidades indicadas pelos métodos testados.

\begin{tabular}{|c|c|}
\hline Método & Coeficientes de correlação ( $r)$ \\
\hline & $\mathrm{pH} \mathrm{CaCl} 24,9$ \\
\hline \multirow{4}{*}{$\begin{array}{l}\text { SMP } \\
\text { Saturação de bases } \\
\text { Al trocável }\end{array}$} & $r=0,980 * *$ \\
\hline & $r=0,871 * *$ \\
\hline & $r=0,707 \% *$ \\
\hline & $\mathrm{pHCaCl}{ }_{2} 5,4$ \\
\hline \multirow{3}{*}{$\begin{array}{l}\text { SMP } \\
\text { Saturação de bases }\end{array}$} & $r=0,961 * \%$ \\
\hline & $r=0,930 \%$ \\
\hline & $\mathrm{pH} \mathrm{CaCl} 25,9$ \\
\hline SMP & $r=0,937 \% *$ \\
\hline Saturação de bases & $r=0,928 * *$ \\
\hline Acetato de cálcio & $r=0,979 * *$ \\
\hline
\end{tabular}


ses recomendadas, para solos com poder tampão mais elevado, e superestimar essas doses, em solos com baixa capacidade tampo nante, conforme é observado quando se comparam as necessida des de carbonato de cálcio requeridas para neutralizar os teo res de $\left(\mathrm{H}^{\mathrm{O}}+\mathrm{Al}^{3+}\right)$ determinados após a extração com acetato de cálcio (tabela 2) com as necessidades obtidas por incuba ção *

A efficiência do método do acetato de cálcio tem sido comprovada em inumeros trabalhos realizados em solos brasileiros, como os de FREITAS et alii (1968) em solos do es tado de São Paulo, DEFELIPO et alii (1972) em solos de Minas Gerais e KAMINSKI (1974) em solos do Rio Grande do Sul. Uma das principais justificativas para não ser empregado em laboratórios de rotina para recomendações de calcário, tem sido pelo fato de exigir titulação como forma de medida da acidez, recomendando-se seu uso para laboratórios de pesquisa (FREI TAS et alii, 1968), porém ressalvando-se sua tendência em subestimar corretivos para controle do $\mathrm{pH}$ em $\mathrm{H}_{2} \mathrm{O}, 6,5$ (KAMINSKI, 1974)* A viabilidade de se estimar os teores de $\mathrm{H}^{\circ}+\mathrm{Al}^{+3}$ a partir de leituras diretas do $\mathrm{pH}$ da suspensão solo:água:solução SMP, evidenciada pelos trabalhos de RAlJ et alii (1979), QUAGGIO (1983a), e ratificada pelos resultados aqui obtidos, sugerem a possibilidade do seu emprego em condições de rotina, principalmente para el evação do $\mathrm{pH}$ a valores mais altos. 0 método SMP, conforme empregado no presente estudo, revelou-se também um método satisfatório na indicação das quantidades de corretivos da acidez a serem aplicadas, correlacionando significativamente com os valores indicados pela incubação. Estes dados eram esperados, uma vez que os testes realizados com o método, nas mais variadas condições - 
de solo, tem comprovado sua eficiência no controle do $\mathrm{pH}$ (Mc LEAN et al ii, 1966; FREITAS et alii, 1968; KAMINSKI, 1974). Torna-se necessário, entretanto, calibrar o método para cada região, uma vez que as doses recomendadas diferem bastante em função dos tipos de solos trabalhados (souzA et alii, 1980).Assim, FREITAS et alii (1968) quando testaram o método SMP em solos do estado de São Paulo, tal como utilizado originalmente, verificaram que este recomendava o dobro da quantidade de calcário requerida por incubação. Este problema foi contornado, segundo os autores, pelo uso de menor quantidade de solo em relação ao tampão. Apesar disso, o intervalo entre as doses recomendadas foi muito elevado $(1,2$ t/ha) para cada variação no pH da suspensão solo: água:tampão SMP de 0,1 unidades. Este fato tornou o método pouco sensível para solos com baixa necessidade de calagem, sendo uma das principais razões para o desestímulo à utilização do método em solos daquele estado. 0 método SMP foi testado ainda em 20 solos do município de Pira cicaba (CATANI \& ALONSO, 1969) tendo se revelado eficiente na indicação da necessidade de calcário. Comparando-se a equação de regressão obtida por estes autores entre o pH SMP e a ne cessidade de carbonato obtida por incubação para $\mathrm{pH} \mathrm{H}_{2} \mathrm{O} \quad 6,5$ ( $\mathrm{N} . \mathrm{C}$. incubação $\left(t \mathrm{CaCO}_{3} / \mathrm{ha}\right)=42,56-6,05 \mathrm{pH} \mathrm{SMP,} \mathrm{r}=0,90$ ) observa-se que as quantidades de carbonato de cálcio diferem bastante das encontradas neste trabalho, para os valores mais baixos de pH SMP. Provavelmente isto tenha ocorrido porque na quel e trabalho utilizou-se o método tal como originalmente proposto, e neste, a modificação proposta por MIELNICZUK et alii (1969). A maior amplitude de variação nos valores de $\mathrm{pH}$ SMP, aqui encontrada, possivelmente tenha-se originado do uso de menor volume do tampão, porém mais concentrado, aumentando 
assim a sensibilidade do método.

As quantidades de carbonato de cálcio indica das pelo método da saturação de bases, com as modificações in troduzidas neste trabalho, mostraram-se também bem correlacio nadas com as doses indicadas pela incubação, sendo os coefi cientes de correl af̧ăo mais elevados nos dois últimos níveis de $\mathrm{pH}$ a serem atingidos. Os resultados, nestes casos, são com paráveis aos obtidos com o método SMP, sendo superado por este quando se deseja elevar o $\mathrm{pH} \mathrm{H}_{2} \mathrm{O}$ a 5,5 (tabela 8) ou o pH em $\mathrm{CaCl}_{2}$ a 4,9 (tabela 9). Estes resultados confirmam a viabilidade de emprego deste método nas recomendações rotineiras de calcário, tendo em vista que mesmo para elevação do $\mathrm{pH} \mathrm{H}_{2} \mathrm{O}$ a 5,5, o método superou em eficiência o método do alumínio trocável, tendo em vista o baixo coeficiente de correlação ve rificado pelo mesmo. Sua principal vantagem em relação aos de mais métodos é o de ser mais flexível nas doses de calcário recomendadas, podendo a saturação de bases a ser atingida variar em função da cultura a ser implantada, dependendo da sua maior ou menor exigência em bases trocáveis, e portanto em valores de $\mathrm{pH}$. Deve-se ressaltar entretanto, sua tendência em subestimar as doses a serem aplicadas, principalmente quando se deseja atingir baixos valores de $\mathrm{pH}$, em alguns solos.

o método do alumínio trocável, quando comparado com os demais mostrou-se menos efetivo para elevação do $\mathrm{pH}$ em $\mathrm{H}_{2} \mathrm{O}$ ao valor 5,5 (tabela 8). Provavelmente o baixo coefi ciente de correlação obtido entre as doses recomendadas pelo mesmo e as doses indicadas pelo método da incubação tenha o corrido em função da extrema discrepância de valores em algumas amostras (amostras 7, 9, 12, 19 e 21), tendo em vista que nas demais as quantidades recomendadas são muito similares. - 
Como a finalidade última deste método não é o aumento do $\mathrm{pH}$ até valores estipulados, mas sim a neutralização dos níveis tóxicos de alumínio trocável nos solos, tal método geralmente perde em eficiência quando comparado com outros que comumente estimam, conjuntamente, outras formas de acidez:

Comparando-se os resultados mostrados nas tabe las 8 e 9, observa-se que ocorre uma sensivel aproximação nos valores de $\mathrm{CaCO}_{3}$ indicados pelos vários métodos em rela ção aos indicados pela incubação, quando as quantidades tomadas por este método são obtidas das curvas de neutralização dos solos com leituras de $\mathrm{pH}$ em $\mathrm{CaCl}_{2}$. Isto é comprovado também pelos mais altos coeficientes de correlação encontrados, neste caso, para todos os métodos testados (tabelas $10 \mathrm{e} 11$ ): Constatações semel hantes foram expostas e comentadas no decor rer do trabalho, com outras correl ações efetuadas. As hipóteses para que tais fatos tenham ocorrido são várias, porém a mais provável é a de que durante o processo de incubação dos solos ocorra produção de sais pela mineralização da matéria orgânica, afetando as leituras do $\mathrm{pH}$ em $\mathrm{H}_{2} \mathrm{O}$. Tais leituras não seriam, ou seriam menos afetadas pela leitura do pH em so l ução salina. Como as necessidades de carbonato de cálcio obtidas pela incubação dos solos são obtidas das suas curvas de neutralização, as quantidades de cárbonato de cálcio requeridas para elevação do pH a valores determinados tendem a estar mais sujeitas a variações quando as leituras de pH são feitas em águá, o que possivelmente não ocorra em suspensões de solo onde a concentração sal ina é uniformizada.

Dados semel hantes foram obtidos por PIONKE et alii (1968) com 126 amostras de solos de Wisconsin (EUA)= Os autores compararam as doses recomenciadas por vários métodos - 
com as doses indicadas pela incubação dos solos para el evação do $\mathrm{pH}$ em $\mathrm{H}_{2} \mathrm{O}$ a 6,5 e $\mathrm{pH}$ em KCl a 6,0 , obtendo mais altos coeficientes de correl ação no último caso para todos os métodos testados, exceto para o da saturação em bases.

Sugere-se a realização de estudos mais detal ha dos a respeito, utilizando-se amostras com maior variação nas propriedades físicas e quimicas e restritas ao horizonte su perficial, pois isto permitiria a obtenção de dados mais real istas sobre a recomendação de cal cário pelos diversos méto dos, caso se repitam e se confirmem os resultados obtidos no presente trabalho. 


\section{5* CONCLUSÕES}

Com base nas condições em que o trabalho experimental foi conduzido e nos resultados obtidos, pode-se chegar as seguintes conclusões:

5:1. A capacidade de troca de cátions dos solos estudados mostrou-se relacionada com o teor de argila e teor de matéria orgânica.

5.2. As propriedades dos solos, que mais influ enciaram na sua necessidade de calcário foram, por ordem de importância, a acidez potencial $\left(H^{\circ}+A l^{3+}\right), C T C$ a $\mathrm{pH}^{3+}, 0,-$ teor de argila e teor de matéria orgânica.

5.3. $0 \mathrm{pH}$ em H $\mathrm{H}_{2} \mathrm{O}$ ou em solução de $\mathrm{CaCl}_{2} 0,01 \mathrm{M}$ aumenta linearmente com o aumento da saturação em bases dos solos, havendo estreita correl ação entre estas variáveis. 5:4. $0 \mathrm{pH}$ da suspensão solo:água: solução SMiP está significativamente relacionado com os teores de $\left(\mathrm{H}^{\mathrm{O}}+\mathrm{Al}^{3+}\right)$ extraídos por solução de acetato de cálcio IN, tamponada a pH 7,0. Em função disso, é possível avaliar-se a CTC dos solos, com precisão semelhante à obtida com o procedimento normal, bastando acrescer à soma de bases, os teores 
de $\left(\mathrm{H}^{\mathrm{O}}+\mathrm{Al}^{3+}\right)$ obtidos por leitura dos valores do $\mathrm{pH}$ SMP, em equação de regressão ou tabela previamente aferida. Tal proce dimento é mais rápido e mais adaptável as condições de rotina. 5.5. 0 método do acetato de cálcio, previamente cal ibrado com o método da incubação para elevação do $\mathrm{pH}$ em $\mathrm{H}_{2} \mathrm{O}$ a 6,5 e pH em. $\mathrm{CaCl}_{2}$ a 5,9 , mostrou-se o método de recomen dação de calcário mais eficiente para elevação do $\mathrm{pH}$ aos valo res citados, dentre os quatro métodos testados.

5:6. O método SMP, modificado segundo MIELNICZUK et alii (1969), e o método da saturação em bases, mostraram-se também efetivos na indicaçào de corretivos para elevar o $\mathrm{pH}$ em $\mathrm{H}_{2} \mathrm{O}$ e em $\mathrm{CaCl}_{2}$ a distintos valores, embora menos que o anterior.

5.7. 0 método do alumínio trocável é menos eficiente que os anteriores, na recomendação de calcário para el evação do $\mathrm{pH}$ em $\mathrm{H}_{2} \mathrm{O}$ a 5,5 e $\mathrm{pH}$ em $\mathrm{CaCl}_{2}$ a 4,9 .

5.8. As quantidades de carbonato de cálcio indicadas pelo método ca incubação são mais precisas quando obtidas da evolução do pH das amostras em solução salina de $\mathrm{CaCl}_{2}$ 0,01M, em virtude da el iminação de variações pela produção de sais durante a incubação. As doses de carbonato de cálcio indicadas pelos métodos correlacionam-se assim melhor do que quando comparadas com as indicadas pelo método da incubação para el evação do $\mathrm{pH}$ em $\mathrm{H}_{2} \mathrm{O}$. 


\section{LITERATURA CITADA}

ADAMS, $F=$ e $C=E$. EVANS. 1962. A rapid method for measuring l ime requirement. Soil Sc. Soc. Amer Proc: Madison, 26: $355-357$ *

BHUMBLA, D.R: e E*0. Mc LEAN. 1965. Aluminum in soils: VI Changes in pH dependent acidity, cation exchange capacity and extractable aluminum whith additions of 1 ime to acid surface soils. Soil Sci. Soc. Amer. Proc. Madison, 29:370374 *

BLACK, C.A. 1975. Relaciones suelo-planta. Ed. Hemisferio Sur. Buenos Aires, Tomo 1. 444p.

BROWN, I.C. 1943. A rapid method of determining exchangeable hidrogen and total exchangeable bases of soils. Soil Scin, Baltimore, 56:353-357

CAMARGO, O.A. e B* VAN RAIJ. 1975. Relações entre o alumínio trocável, bases trocáveis e pH em solos. In: Anais do XI Congresso Brasileiro de Ciência do Solo, Campinas,p.95-101 
CATANI, R:A. e J.R. GALLO, 1955. Avaliação da exigência de calcário dos solos do Estado de São Paulo mediante a correlação entre o pH e saturação de bases. Rev.da Agricultura, Piracicaba, 30: 49-60.

CATANI, R.A. e 0. ALONSO, 1969. Avaliação da exigência de cal cário do solo. Anais da Esc. Sup. Agric. "Luiz de Queiroz". Piracicaba, 26: $141-156$.

CATANI, R:A. e A. O, JACINTHO, 1974. Avaliação da Fertilidade do Solo. Métodos de Análise. Ed. Ave Maria, São Paulo, 6lp. CATE, R.B. 1965. Sugestões para adubação com base na análise de solo. North Carolina State University. Int. Soil Testing, Project, Raleigh, 16p. COLEMAN, N.T., E.J. KAMPRATH e S. B. WEED. 1958. Liming. Advance Agron:, 10:475-522

COLEMAN, N.T., S.B. WEED e R.J. Mc CRACKEN. 1959. Cation exchange capacity and exchangeable cations in Piedmont soils of North Carolina. Soil Sci. Soc, Amer. Proc, Madison, 23: 1 46-149.

COLEMAN, N.T* e D. CRAIG. 1961. The spontaneous al teration of hidrogen clay. Soil Sciz, Baltimore, 91:14-18. COLEMAN, N.T. e G.W. THOMAS. 1967. The basic chemistry of soil acidity* In: FEARSON, R.W. e F. ADAMS.(ed.) So il Acidity and Liming: Amer. Soc. Agronomy, Madison, Agronomy. |2: $1-4 \mid$ *

CURTIN, D. e G.W. SMILLIE. 1983. Soil solution as affected by liming and incubation. Soil Sci. Soc. Amer. J., Madison, 47: $701-707$.

DAVIS, L.E., R.TURNER e L.D. WHITIG. 1962. Some studies of the autotransformation of H-bentonite to Al-bentonite. Soil Sci. Soc. Amer. Proc:, Madison, 26: 441-443. 
DEFELIPO, B* V*, J*M* BRAGA e C* SPIES* 1972. Comparação entre métodos de determinação da necessidade de calcário de solos de Minas Gerais. Experientiae, Viçosa, UFV, 13(4):111-136. DEVILIERS, J*M: e M:L. JACKSON* 1967. Cation exchange capacity variation whith $\mathrm{pH}$ in soil and clays. Soil Sci, Soc. Amer: Proce. Madison, $\underline{.31}: 473-476$.

DEWAN, H.C. e C.I. RICH* 1970. Titration of acid soils: Soil Sci. Soc. Amer. Procz, Madison, 34:38-44.

FASSBENDER, $H_{2} W_{*}$ 1975: Química de Suelos. Con enfasis em suelos de America Latina. Instituto Interamericano de Ciências Agrícolas de la OEA. Turrialba, Costa Rica, Ed* de La Cruz * 398p: (Ser. Libros y Materiales Educativos).

FREITAS, L*M*M*, P*F* PRATT e L* VETTORI. I968. Testes rápi dos para estimar a necessidade de calcário em alguns solos do Estado de São Paulo. Pesq. Agropec. Bras,, Ser. Agron, ,Rio de Janeiro, $\underline{3}:$ I 59-164: HARWARD, M.E* e N*T. COLEMAN. 1954: Some properties of $H$ and Al clays and exchange resins. Soil Scix, Baltimore, 79: $181-188$.

HELLING, C*S*, S* CHESTERS e R*B* COREY: 1964: Contribuition of organic matter and clay to soil cation-exchange capacity as affected by the $\mathrm{pH}$ of saturation solution. Soil Sci. Soc. Amer. Procn, Madison, 28: 517-520.

JACKSON, M:L: 1963* Aluminum bonding in soils: A unifying principle in soil science. Soil Sci, Soc. Amer. Proc*, Madison, 27: 1-9.

JENNY, $H=1961$. Reflections on the soil acidity merry-go-round. Soil Sci. Soc. Amer. Proc,, Madison, 25:428-431. 
KAMINSKI, J. 1974. Fatores da acidez e necessidade de calcá rio em solos do Rio Grande do.Sul. Porto Alegre, Faculdade de Agronomia, UfRGS. 96p: (Tese mestrado em Agronomia - Solos)*

KAMPRATH, E.J. 1967. Soil acidity and response to I iming: International Sail Testing. North Carol ina State University, Raleigh, N.C. (Technicall Bulletin no 4). KAMPRATH, Ex J. 197,0. Exchange aluminum as a criterion for liming leached mineral soils. Soil Sci. Soc. Amer. Proc*, Madison, 34:252-254.

KEENEY, D:R: e R:B: COREY: 1963. Factors affecting the 1 ime requirement of Wiscorsin soils. Soil Sci. Soc. Amer. Proc*, Madison, 27: 277-280.

KINJO, T. Conceitos... de acidez dos solos, In: RAIJ, B* VAN, 0. C. BATAGLIA e NaM. SILVA (Coordz). Acidez e calagem no Brasil. XV Reunião Brasileira de Fertilidade do Solo. Campi nas, Soc: Bras. Ciência do Solo, $p \times 24-31$.

LIN , C e N.T. COLEMAN* 1960. The measurement of exchangeable aluminum in soils and clays. Soil Sci. Soc. Amer. Proc*, Madison, 24:444-447.

LOW, P.F. 1955. The role of aluminum in the tritations of bentonite. Soil Scix Soc. Amer. Proc, Madison, 19:135-139. MALAVOLTA, E* e T. COURY. 1954. Determinação da matéria orgânica: Apostilas de Práticas de Química Agrícola, Centro Aca dêmico "Luiz de Queiroz", Piracicaba (mimeog:).

Mc LEAN, E. O., M.R. HEDDLESON e G.J. POST: 1959. Al uminum in soils: 1II. A comparison of extration methods for soils and clays. Soil Sci= Soc. Amer. Prock, Madison, 23:289-293. 
Mc LEAN, E.0. 1965. Aluminum, In: BLACK, C. A. et al i (ed). Methods of soil analysis, Part 2. Madison, ASA, p. 978997 (Agronomy series, 9).

Mc LEAN, E* O., D. C. REICOSKY e C. LAKSHANAN* 1965. Al uminum in soils: VII. Interrelationships of organic matter, liming and extractable aluminum whith "permanent charge" (KCl) and $\mathrm{pH}$ dependent cation-exchange capacity of surface soils. Soil Sci. Soc. Amer Proc:, Madison, 29:374-378.

Mc LEAN, E. O., S.W. DUMFORD e F. CORONEL = 1966. A comparison of several methods of determining 1 ime requirements of soils. Soil Sci. Soc. Amer. Proc., Madison, 30:26-30.

Mc LEAN, E: 0, e E.J. OWEN. 1970. Effects of the pH on the contributions of organic matter and clays to soils cationexchange capacity. Soil Sci. Soc* Amer. Proc*, Madison, 33: 855-858.

licheAN, E*0. 1976. Chemistry of soil aluminum. Commun. Soil Sci. Plant Anal., Z (7):619-636.

MIELNICZUK, J., A. LUDWICK e H.BOHNEN* I 969: Recomendações de adubo e calcário para solos e culturas do Rio Grande do Sul. Porto Alegre. Faculdade de Agronomia, UFRGS: 38p: (Boletim Técn ico, 2).

PEECH, M: e R. BRADFIELD. 1948. Chemical methods for estimating 1 ime needs of soils* Soil Sci, Baltimore, 65:35-55.

PEECH, M*, R:L. COWAN e J.H. BAKER. 1962. A critical study of the $\mathrm{BaCl}_{2}$-triethanolamine and the ammonium acetate methods for determining the exchangeable hidrogen content of soils. So il Scix Soc. Amer. Proc*, Madison, 26:37-40.

PEECH, M. I965a. Lime requirement. In: BLACK, C. A. et al i i (ed). Methods of Soils Analysis, Part 2. Madison, ASA, p. 927-932 (Agronomy series, 9). 
PEECH, M. 1965b. Hydrogen-ion activity. In: BLACK, C.As et alii (ed). Methods of soil Analysis, Part 2. Madison, ASA, P. 914-925. (Agronomy series, 9).

PIONKE, H.B. e R. B. COREY: 1967. Relation between acidic aluminum and soil pH, clay and organic matter. Soil Sci. Soc. Amer Proc., Madison, 31:749-752.

PIONKE, H.B., R. B. COREY e E.E. SCHULTE. 1968. Contributions of soil factors, to 1 ime requirement and $I$ ime requirement tests. Soil Sci. Soc. Amer. Proc., Madison, 32:113-117. PRATT, P.F. 196I. Effect of $\mathrm{pH}$ on the cation exchange capacity of surface soils. Soil Sci. Soc. Amer. Proce, Madison, 25: 96-98.

PRATT, P.F. e F.L. BAIR= 1961. A comparison of tree reagents for the extration of aluminum from soils. Soil Sci., Baltimore, 91:357-359.

QUAGGIO, J.A. 1983a. Critérios para calagem em solos do Estado de São Paulo. Piracicaba, ESALQ/USP, 76p. (Tese de Mes trado).

QUAGGIO, J.A. 1983b. Métodos de laboratório para a determinação da necessidade de cal agem em solos. In: RAlJ, B. VAN,0. C. BATAGLIA e N.M. SILVA (Coord). Acidez e calagem no Brasil. XV Reunião Brasileira de Fertilidade do Solo. Campinas, Soc. Bras. Ciência do Solo, p. 33-48.

RAIJ, B. VAN, M.T.D. SACCHETTO e T.IGUE: 1968. Correlação entre o $\mathrm{pH}$ e o grau de saturação em bases nos solos com horizonte B textural e horizonte B latossólico. Bragantia, Campinas, 27:193-200.

RAIJ, B. VAN. 1969. A capacidade de troca de cátions das frações orgânica se mineral em solos. Bragantia. Campinas, 28: $85-112$. 
RAIJ, B. VAN, H. CANTARELLA e M.A.T. ZULLO. 1979. 0 método tampão SMP para a determinação da necessidade de calagem de solos do Estado de São Paulo. Bragantia. Campinas, 38:57-69. RANZANI, G., 0. FREIRE e T. KINJO. 1966. Carta de Solos do Mu nicípio de Piracicaba. 85p. (mimeografado).

ROSS, G.J., K.LAWTON e B.G. ELLIS. I 964. Lime requirement related to physical and chemical properties of nine Michigan soils. Soil Sci., Soc. Amer. Proc., Madison, 24:457-460.

SCHOENAKER, H.E., E.O. McLEAN e P.F. PRATT. I96I. Buffer methods for determining I ime requirement of soils with appreciable amounts of extractable aluminum. Soil Sci. Soc. Amer. Proc., Madison, 25: 274-277.

SOUZA, D.M.G., L.N. MIRANDA, E. LOBATO e H.J. KLIEMAN. 1980. A valiação de métodos para determinar as necessidades de calcário em solos de cerrado de Goiás e do Distrito Federal. R. bras. C. Solo. Campinas, 4: $144-148$.

THOMAS, 6.W. 1960. Forms of aluminum in cation exchangers. In: International Congress of Soil Science; 7‥ Madison, 11, 47: 364-369.

TOBON, J.H. e A. LEON. I97I. Comparacion de vários métodos pa ra determinar requirementos de cal en algunos suelos colombianos. Suelos Equatoriales, "acidez y encal amiento en el tropico". Primer Colóquio de suelos, Medellin, Colombia, So ciedad Colombiana de I a Ciencia del Suelo, $\underline{3}: 66-87$.

VETTORI, L. 1948. Determinação da necessidade de cal dos solos. Instituto de Quimica Agrícola. Rio de Janeiro, 19p. (Boletim, 7).

VETTORI, L. 1969. Métodos de análise de solo. Ministério da $\underline{A}$ gricultura. Equipe de Pedologia e Fertilidade do Solo. Rio de Janeiro, 24p. (Boletim Técnico, 7). 
WOODRUFF, C.M. 1948. Testing soils for 1 ime requirement by means of a buffered solution and the glass eletrode. Soil Sci., Baltimore, 66:53-63.

YUAN, T.L. 1959. Determination of exchangeable hydrogen in soils by a tritation method. Soil Sci., Baltimore, 88:164-167. YUAN, T.L. 1963. Some relationships among hydrogen, aluminum, and $\mathrm{pH}$ in solution and soil systems. Soil Sci., Baltimore, 95: $155-163$.

YUAN, T.L. 1974. A double buffer method for the determination of 1 ime requirement of acid soils. Soil Sci. Soc. Amer: Proce, Madison, 38: 437-440. 
7. APÊNDICE 


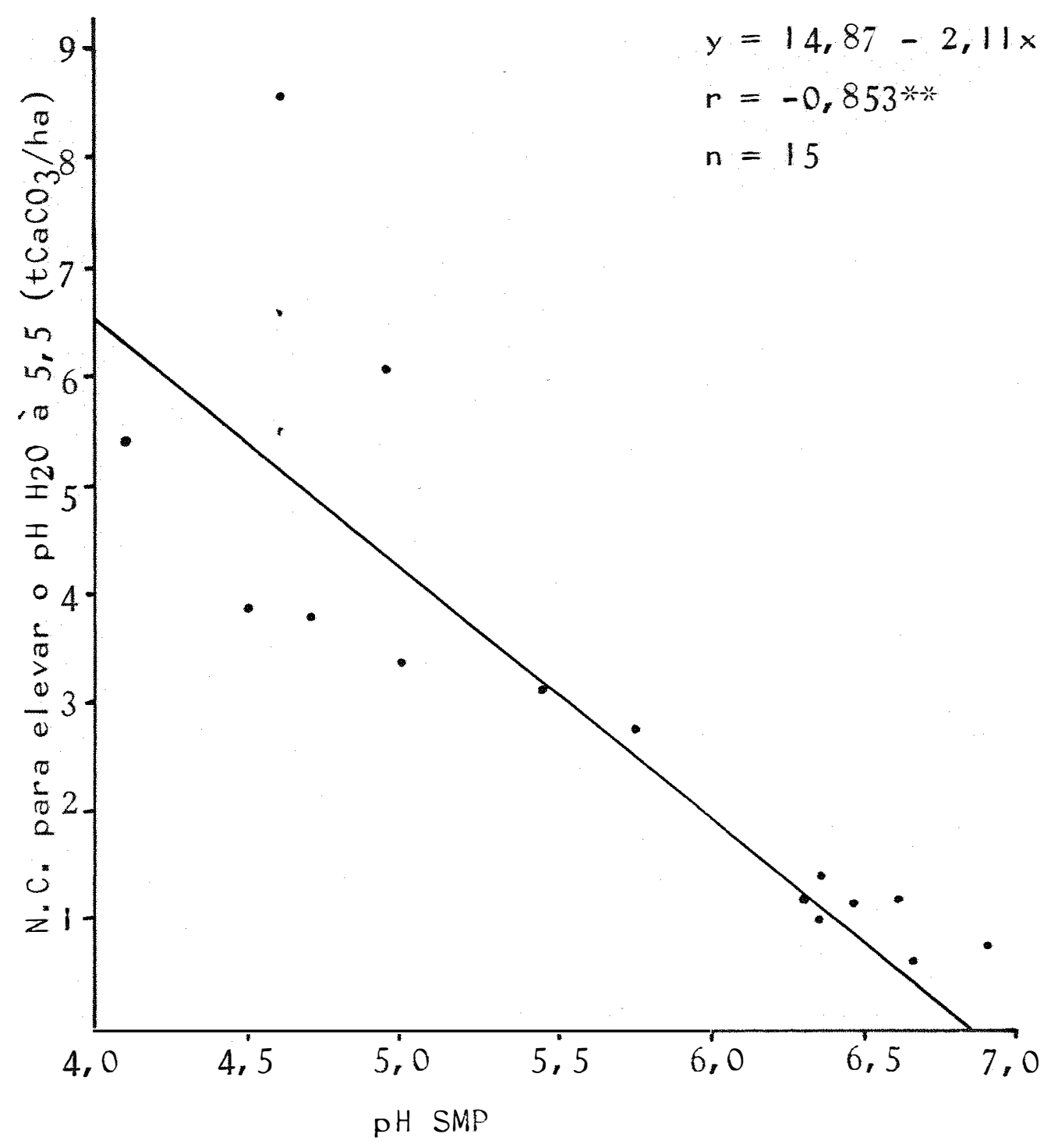

Figura 1 - Relação entre o pH da suspensão solo: água - solução SMP e a necessidade de calcário obtida por incubação para el evar o $\mathrm{pH}$ em $\mathrm{H}_{2} \mathrm{O}$ ao valor 5,5. 


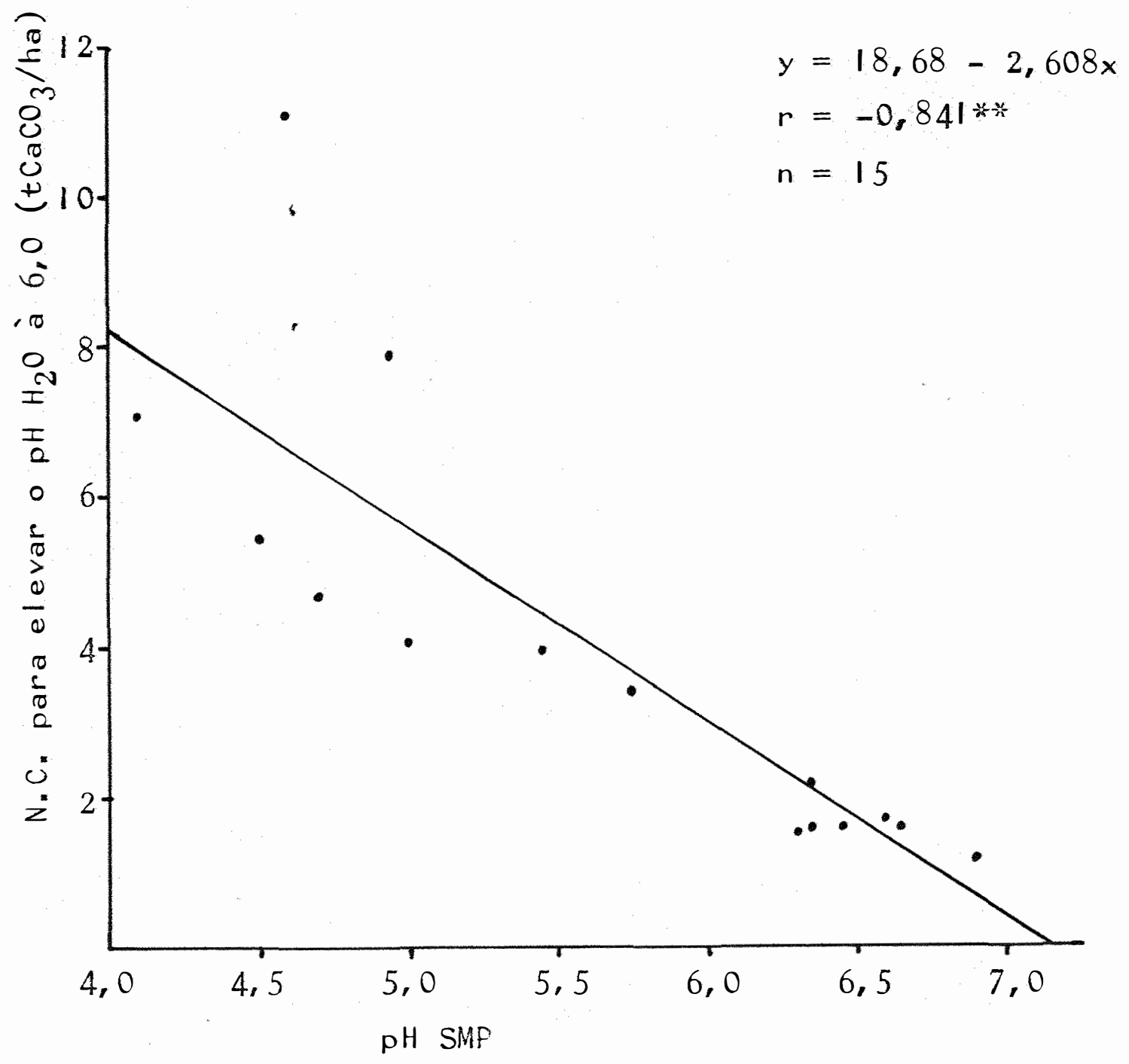

Figura 2 - Relação entre o pH da suspensão solo:água: solução SMP e necessidade de calcário obti da por incubação para elevar o pH em $\mathrm{H}_{2} \mathrm{O}$ ao valor 6,0 . 


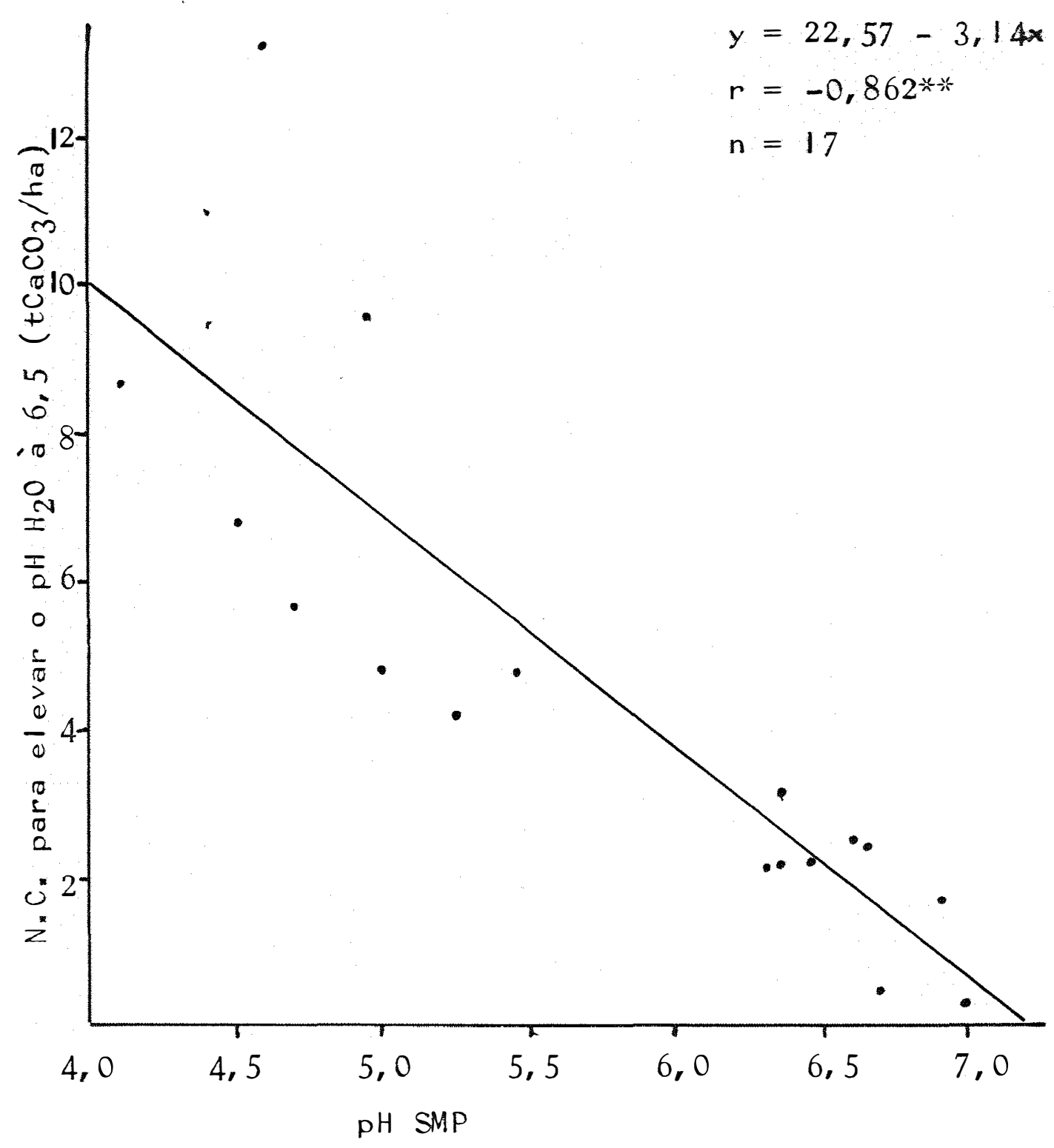

Figura 3 - Relação entre o pH da suspensão solo:água: solução SMP e a necessidade de cal cário obtida por incubação para elevar o $\mathrm{pH}$ em $\mathrm{H}_{2} \mathrm{O}$ ao valor 6,5 . 


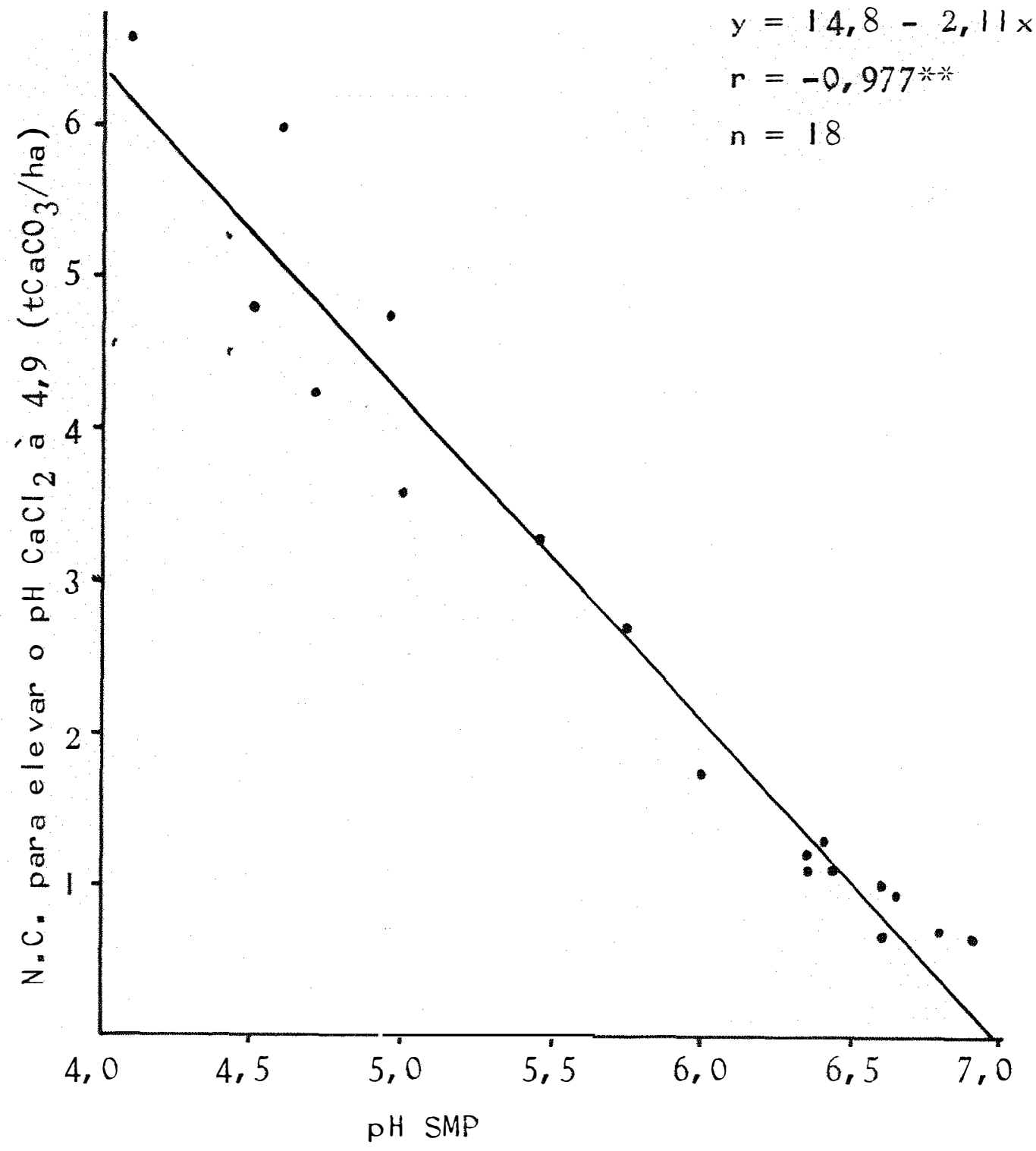

Figura 4 - Relação entre o pH da suspensão solo: água:solução SMP e a necessidade de calcário obtida por incubação para el evar o $\mathrm{pH}$ em $\mathrm{CaCl}_{2}$ ao valor $4,9$. 


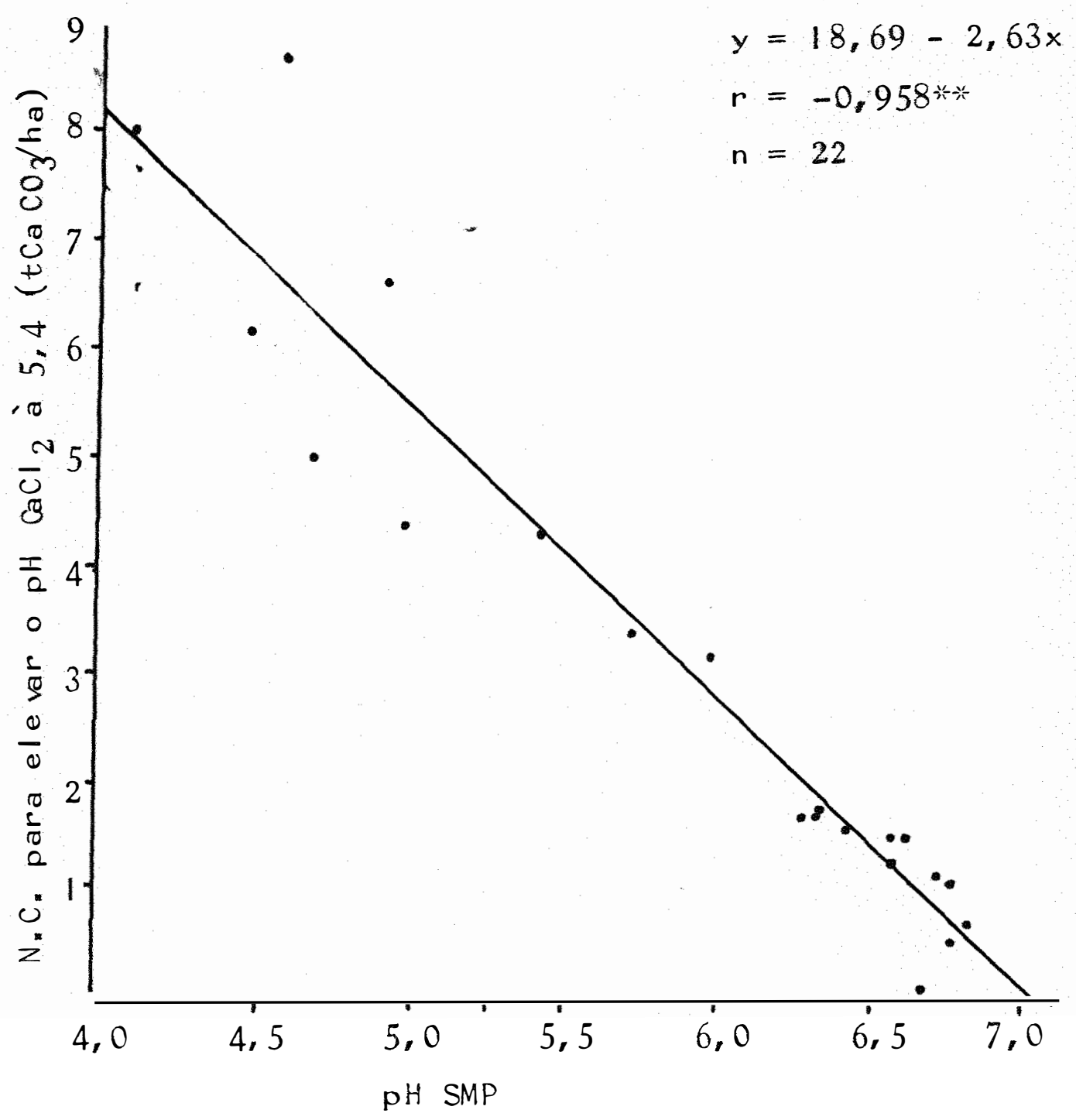

Figura 5 - Relação entre o pH da suspensão solo:água:solução SMP e a necessidade de calcário obtida por incubação para elevar - $\mathrm{pH}$ em $\mathrm{CaCl}_{2}$ ao valor 5,4 . 


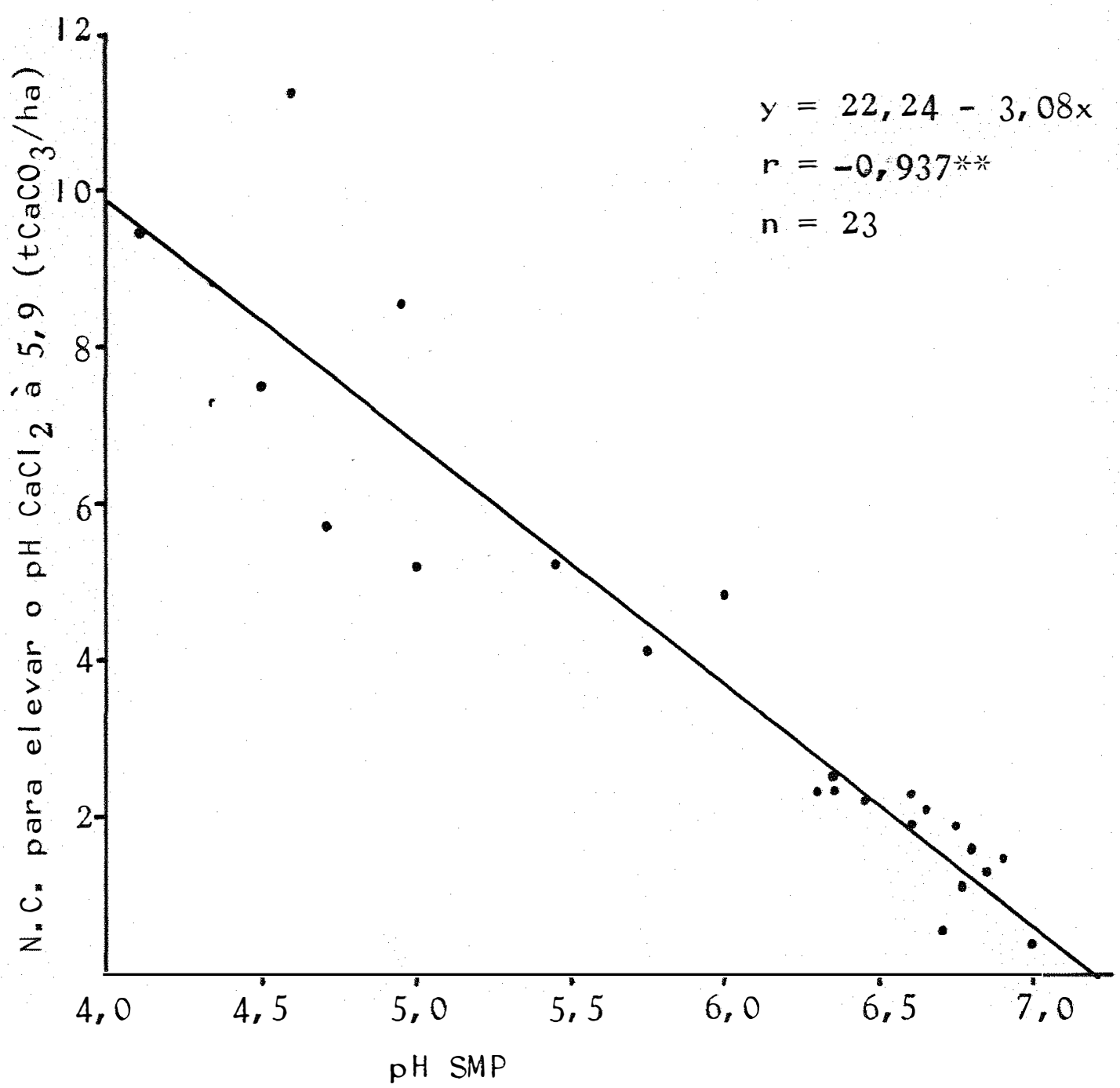

Figura 6 - Relação entre o $\mathrm{pH}$ da suspensão solo:água: solução SMP e a necessidade de calcário ob tida por incubação para elevar o pH em $\mathrm{CaCl}_{2}$ ao valor 5,9. 